Prepared in cooperation with the San Antonio River Authority

Simulation of Hydrologic Conditions and SuspendedSediment Loads in the San Antonio River Basin Downstream from San Antonio, Texas, 2000-12

\title{
nded-
} ofsing anter. andiction

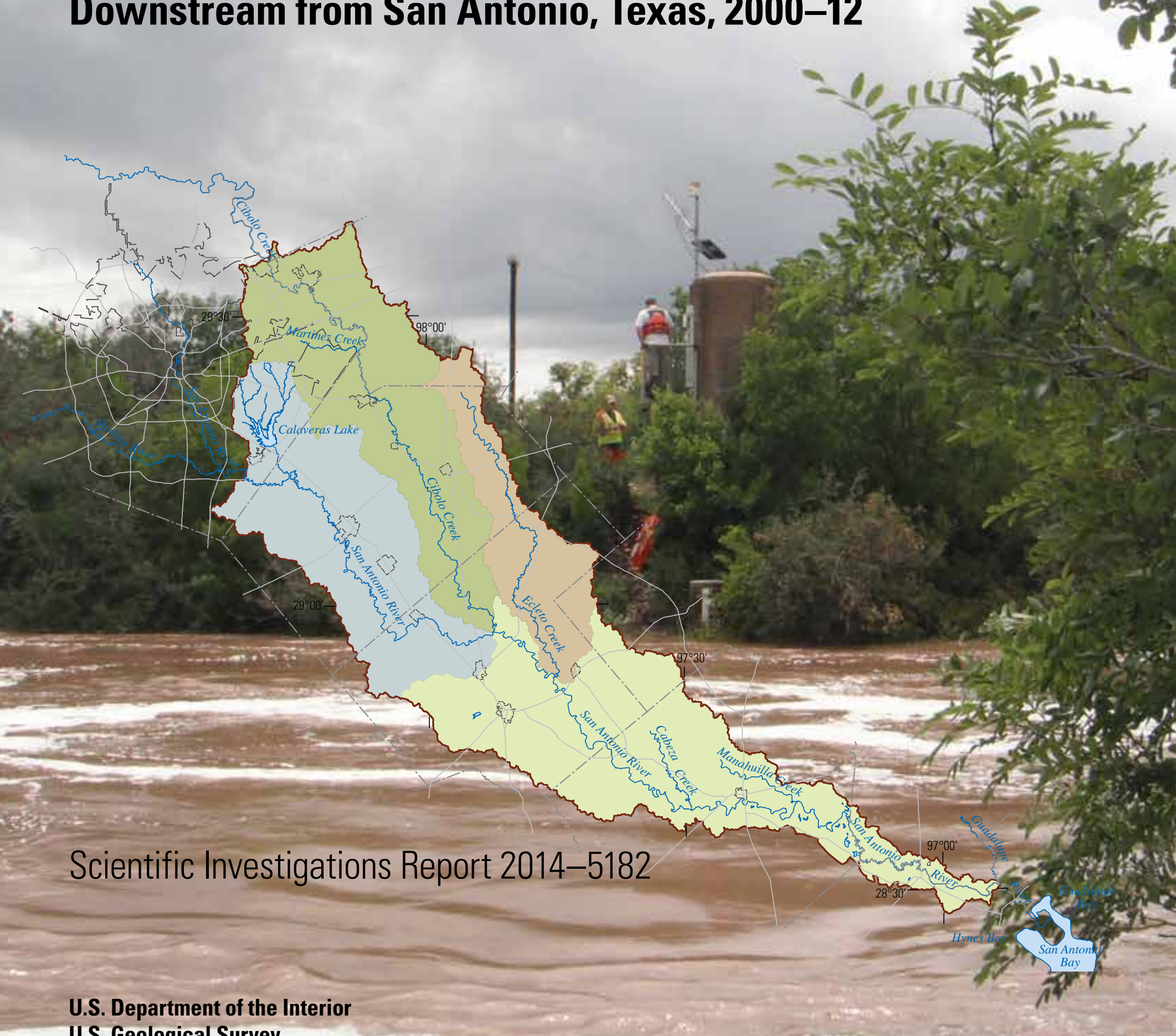
U.S. Geological Survey 
Front cover, Collection of a suspended-sediment sample by hydrologic technicians at U.S. Geological Survey streamflow-gaging station 08185000 Cibolo Creek at Selma, Texas, on May 25, 2013. Photograph by Chiquita Lopez, U.S. Geological Survey.

Back cover, U.S. Geological Survey streamflow-gaging station 08181800 San Antonio River near Elmendorf, Texas, on February 18, 2012. 


\section{Simulation of Hydrologic Conditions and Suspended-Sediment Loads in the San Antonio River Basin Downstream from San Antonio, Texas, 2000-12}

J. Ryan Banta and Darwin J. Ockerman

Prepared in cooperation with the San Antonio River Authority

Scientific Investigations Report 2014-5182 


\section{U.S. Department of the Interior \\ SALLY JEWELL, Secretary}

\section{U.S. Geological Survey \\ Suzette M. Kimball, Acting Director}

\section{U.S. Geological Survey, Reston, Virginia: 2014}

For more information on the USGS — the Federal source for science about the Earth, its natural and living resources, natural hazards, and the environment, visit http://www.usgs.gov or call 1-888-ASK-USGS.

For an overview of USGS information products, including maps, imagery, and publications, visit http://www.usgs.gov/pubprod

To order this and other USGS information products, visit http://store.usgs.gov

Any use of trade, firm, or product names is for descriptive purposes only and does not imply endorsement by the U.S. Government.

Although this information product, for the most part, is in the public domain, it also may contain copyrighted materials as noted in the text. Permission to reproduce copyrighted items must be secured from the copyright owner.

Suggested citation:

Banta, J.R., and Ockerman, D.J., 2014, Simulation of hydrologic conditions and suspended-sediment loads in the San Antonio River Basin downstream from San Antonio, Texas, 2000-12: U.S. Geological Survey Scientific Investigations Report 2014-5182, 46 p., http://dx.doi.org/10.3133/sir20145182.

ISSN 2328-031X (print)

ISSN 2328-0328 (online)

ISBN 978-1-4113-3860-9 


\section{Contents}

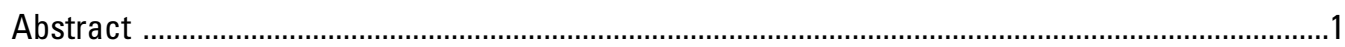

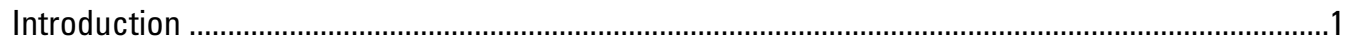

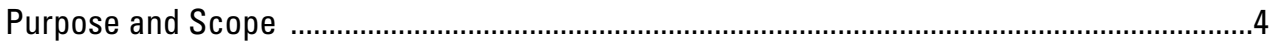

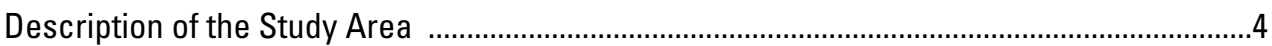

Simulation of the Hydrologic Conditions and Suspended-Sediment Loads ....................................5

Functional Description of Hydrological Simulation Program —FORTRAN .............................5

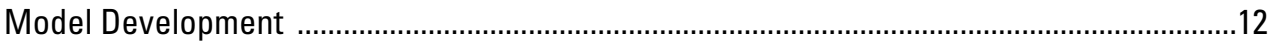

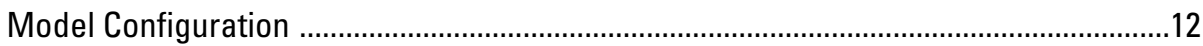

Input Data for the Hydrological Simulation Program—FORTRAN Model ......................12

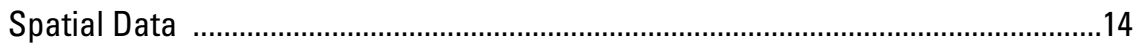

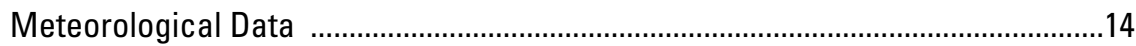

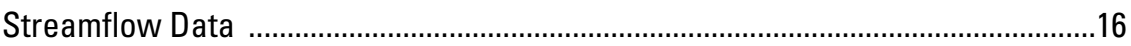

Estimated Suspended-Sediment Loads ................................................................17

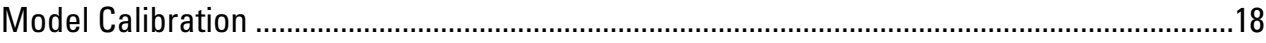

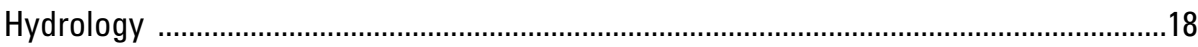

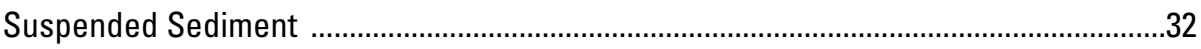

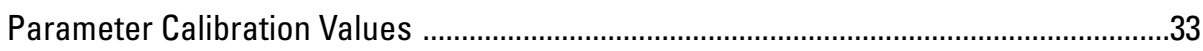

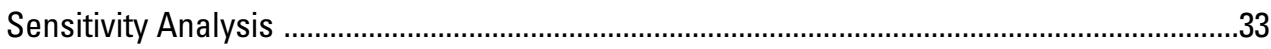

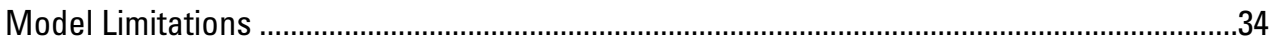

Simulated Hydrologic Conditions in the Study Area in the San Antonio River Basin ............35

Simulated Suspended-Sediment Loads and Yields in the Study Area in the San

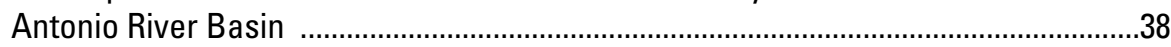

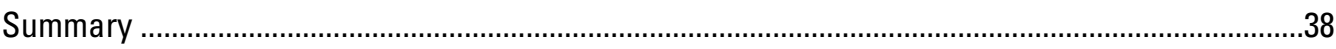

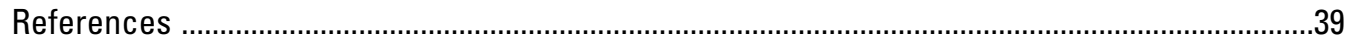

Appendix 1. Hydrological Simulation Program—FORTRAN Parameter Definitions and Values

\section{Figures}

1. Map showing location of sites where Hydrological Simulation ProgramFORTRAN (HSPF) model input data were obtained or HSPF model simulation results were output in the study area, San Antonio River Basin downstream from San Antonio, Texas, 2000-12

2. Map showing surface geology in the study area, San Antonio River Basin downstream from San Antonio, Texas

3. Map showing relative soil infiltration rates in the study area, San Antonio River Basin downstream from San Antonio, Texas

4. Map showing land-cover classification in the study area, San Antonio River Basin downstream from San Antonio, Texas

5. Diagram showing Hydrological Simulation Program—FORTRAN (HSPF) flowchart for hydrologic processes on $A$, impervious land segments and $B$, pervious land segments 
6. Diagram showing Hydrological Simulation Program—FORTRAN (HSPF)

flowchart for sediment processes on $A$, impervious land segments;

$B$, pervious land segments; and $C$, stream reaches

7. Map showing watershed and stream/reservoir reach delineation for the Hydrological Simulation Program-FORTRAN model of the study area, San Antonio River Basin downstream from San Antonio, Texas .13

8. Map showing location of National Weather Service meteorological stations and associated Thiessen rainfall areas in the study area, San Antonio River Basin downstream from San Antonio, Texas 15

9. Graphs showing comparison of $A-C$, Measured and simulated daily mean streamflow at U.S. Geological Survey streamflow-gaging station 08183500, San Antonio River near Falls City, Texas (SAR Falls City gage), 2006-12; $D-F$, Estimated and simulated daily mean suspended-sediment loads at the SAR Falls City gage, 2006-12

10. Graphs showing comparison of $A-C$, Measured and simulated daily mean streamflow at U.S. Geological Survey streamflow-gaging station 08186000 , Cibolo Creek near Falls City, Texas (Cibolo Falls City gage), 2006-12;

$D-F$, Estimated and simulated daily mean suspended-sediment loads at the Cibolo Falls City gage, 2006-12

11. Graphs showing comparison of $A-C$, Measured and simulated daily mean streamflow at U.S. Geological Survey streamflow-gaging station 08186500 Ecleto Creek near Runge, Texas (Ecleto Runge gage), 2006-12; $D-F$, Estimated and simulated daily mean suspended-sediment loads at the Ecleto Runge gage, 2006-12

12. Graphs showing comparison of $A-C$, Measured and simulated daily mean streamflow at U.S. Geological Survey streamflow-gaging station 08188500 , San Antonio River at Goliad, Texas (SAR Goliad gage), 2006-12; D-F, Estimated and simulated daily mean suspended-sediment loads at the SAR Goliad gage, 2006-12

13. Map showing measured and simulated daily mean streamflow and daily mean suspended-sediment loads at selected sites in the study area, San Antonio River Basin downstream from San Antonio, Texas, 2006-12

\section{Tables}

1. Sites where Hydrological Simulation Program-FORTRAN (HSPF) model input data were obtained or HSPF model simulation results were output in the study area, San Antonio River Basin downstream from San Antonio, Texas, 2000-12

2. National Land Cover Dataset categories and percent coverage in the study area, San Antonio River Basin downstream from San Antonio, Texas

3. Wastewater discharges included in the Hydrological Simulation ProgramFORTRAN (HSPF) model of the study area, San Antonio River Basin downstream from San Antonio, Texas, 2000-12

4. Evaluation criteria for Hydrological Simulation Program-FORTRAN (HSPF) model simulation results based on Donigian (2002) and Moriasi and others (2007)

5. Streamflow and suspended-sediment load calibration and testing results, Hydrologic Simulation Program-FORTRAN (HSPF) model of the study area in the San Antonio River Basin downstream from San Antonio, Texas, 2000-12 
6. Rainfall and measured evapotranspiration from rangeland/shrubland on the Carrizo Sand, in Medina County, Texas, compared with rainfall and modelsimulated evapotranspiration from rangeland and shrubland on the Carrizo Sand in the study area, San Antonio River Basin downstream from San Antonio, Tex., 2007-09

7. Reported and simulated ranges of soil erosion rates for land-cover types in south Texas and the study area, San Antonio River Basin downstream from San Antonio, Texas, 2006-12

8. Changes in simulated streamflow and suspended-sediment loads as a result of changes in selected Hydrological Simulation Program-FORTRAN (HSPF) process-related parameter values, 2006-12

9. Simulated hydrologic and suspended-sediment conditions upstream from and within the study area, San Antonio River Basin downstream from San Antonio, Texas, 2006-12

10. Simulated groundwater recharge by water-budget zone in the study area, San Antonio River Basin downstream from San Antonio, Texas, 2006-12

\section{Conversion Factors}

Inch/Pound to SI

\begin{tabular}{|c|c|c|}
\hline Multiply & By & To obtain \\
\hline \multicolumn{3}{|c|}{ Length } \\
\hline inch (in.) & 2.54 & centimeter (cm) \\
\hline inch (in.) & 25.4 & millimeter (mm) \\
\hline foot $(\mathrm{ft})$ & 0.3048 & meter (m) \\
\hline mile (mi) & 1.609 & kilometer (km) \\
\hline \multicolumn{3}{|c|}{ Area } \\
\hline square mile $\left(\mathrm{mi}^{2}\right)$ & 2.590 & square kilometer $\left(\mathrm{km}^{2}\right)$ \\
\hline \multicolumn{3}{|c|}{ Volume } \\
\hline acre-foot (acre-ft) & 1,233 & cubic meter $\left(\mathrm{m}^{3}\right)$ \\
\hline \multicolumn{3}{|c|}{ Flow rate } \\
\hline cubic foot per second $\left(\mathrm{ft}^{3} / \mathrm{s}\right)$ & 0.02832 & cubic meter per second $\left(\mathrm{m}^{3} / \mathrm{s}\right)$ \\
\hline \multicolumn{3}{|c|}{ Mass } \\
\hline pound, avoirdupois (lb) & 0.4536 & kilogram (kg) \\
\hline ton, short (2,000 lb) & 0.9072 & megagram (Mg) \\
\hline ton per day (ton/d) & 0.9072 & metric ton per day \\
\hline ton per day (ton/d) & 0.9072 & megagram per day (Mg/d) \\
\hline
\end{tabular}

Temperature in degrees Celsius $\left({ }^{\circ} \mathrm{C}\right)$ may be converted to degrees Fahrenheit $\left({ }^{\circ} \mathrm{F}\right)$ as follows:

${ }^{\circ} \mathrm{F}=\left(1.8 x^{\circ} \mathrm{C}\right)+32$

Concentrations of suspended sediment in water are reported in milligrams per liter (mg/L).

Vertical coordinate information is referenced to the National Geodetic Vertical Datum of 1929 (NGVD 29) and the North American Vertical Datum of 1988 (NAVD 88).

Horizontal coordinate information is referenced to the North American Datum of 1983 (NAD 83). 



\title{
Simulation of Hydrologic Conditions and Suspended- Sediment Loads in the San Antonio River Basin Downstream from San Antonio, Texas, 2000-12
}

\author{
By J. Ryan Banta and Darwin J. Ockerman
}

\section{Abstract}

Suspended sediment in rivers and streams can play an important role in ecological health of rivers and estuaries and consequently is an important issue for water-resource managers. To better understand suspendedsediment loads and transport in a watershed, the U.S. Geological Survey (USGS), in cooperation with the San Antonio River Authority, developed a Hydrological Simulation Program—FORTRAN model to simulate hydrologic conditions and suspended-sediment loads during 2000-12 for four watersheds, which comprise the overall study area in the San Antonio River Basin (hereinafter referred to as the "USGS-2014 model"). The study area consists of approximately 2,150 square miles encompassing parts of Bexar, Guadalupe, Wilson, Karnes, DeWitt, Goliad, Victoria, and Refugio Counties. The USGS-2014 model was calibrated for hydrology and suspended sediment for 2006-12. Overall, modelfit statistics and graphic evaluations from the calibration and testing periods provided multiple lines of evidence indicating that the USGS-2014 model simulations of hydrologic and suspended-sediment conditions were mostly "good" to "very good." Model simulation results indicated that approximately 1,230 tons per day of suspended sediment exited the study area and were delivered to the Guadalupe River during 2006-12, of which approximately 62 percent originated upstream from the study area. Sample data and simulated model results indicate that most of the suspended-sediment load in the study area consisted of silt- and clay-sized particles (less than 0.0625 millimeters). The Cibolo Creek watershed was the largest contributor of suspended sediment from the study area. For the entire study area, open/developed land and cropland exhibited the highest simulated soil erosion rates; however, the largest contributions of sediment (by land-cover type) were pasture and forest/rangeland/ shrubland, which together composed approximately 80 percent of the land cover of the study area and generated about 70 percent of the suspended-sediment load from the study area.

\section{Introduction}

Suspended sediment in rivers and streams can play an important role in ecological health of rivers and estuaries and consequently is an important issue for water-resource managers. The quantity and type of suspended sediment can affect the biological communities (Wood and Armitage, 1997), the concentration and movement of natural constituents and anthropogenic contaminants (Moran and others, 2012), and the amount of sediment deposition in coastal environments (Milliman and Meade, 1983). A better understanding of the quantity and timing of suspended-sediment loads delivered to the Guadalupe and San Antonio Bays is particularly important because these sediment inflows are critical for maintaining shallow water habitats and wetlands (Texas Commission on Environmental Quality, 2011).

To better understand suspended-sediment loads and transport in a watershed, Hydrological Simulation ProgramFORTRAN (HSPF) models can be developed to simulate hydrologic and suspended-sediment conditions. The HSPF models have been used successfully in south and south-central Texas to represent complex hydrologic processes in the San Antonio River Basin (Lizárraga and Ockerman, 2010), simulate groundwater recharge to the Trinity and Edwards aquifers (Ockerman, 2002, 2007), and simulate suspended-sediment concentrations and loads in the lower Nueces River watershed (Ockerman and others, 2013).

The U.S. Geological Survey (USGS) has collected streamflow and suspended-sediment data at some USGS streamflow-gaging stations within the San Antonio River Basin (fig. 1, table 1) for decades (Crow and others, 2014). However, much of the historical suspended-sediment data were collected during routine conditions (often during base-flow, or low-flow conditions). Because a substantial part of the annual suspendedsediment load can be transported during a small number of floods (Markus and Demissie, 2006), historical sampling might not have adequately characterized sediment transport during high-flow events. Further, much of the historical data did not include an analysis of the particle-size distribution, which is necessary to accurately simulate the suspended-sediment transport using an HSPF model. Recent (2011-13) sediment sampling was focused on sampling larger flow events (Crow and others, 2014). 


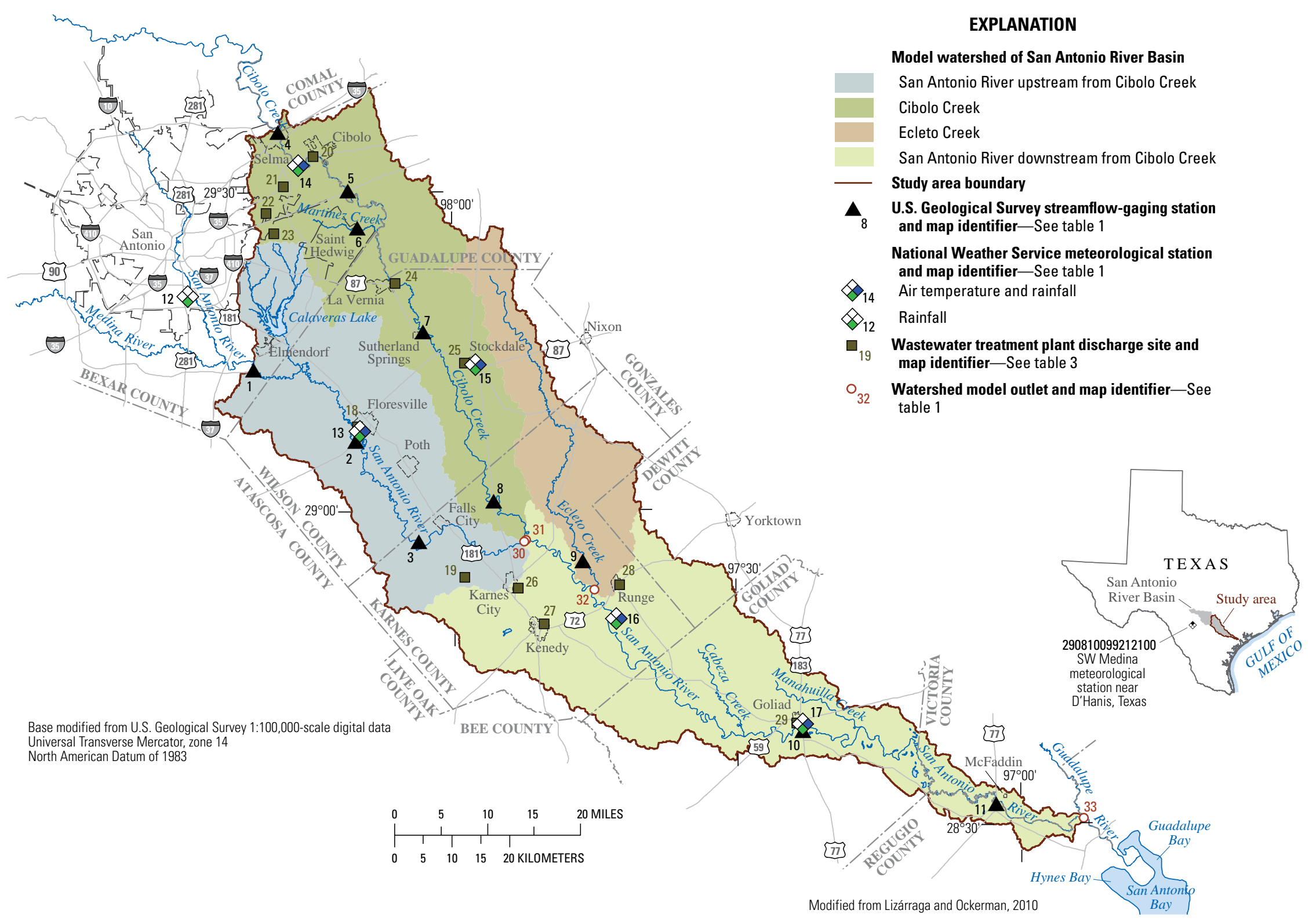

Figure 1. Location of sites where Hydrological Simulation Program-FORTRAN (HSPF) model input data were obtained or HSPF model simulation results were output in the study area, San Antonio River Basin downstream from San Antonio, Texas, 2000-12. 
Table 1. Sites where Hydrological Simulation Program—FORTRAN (HSPF) model input data were obtained or HSPF model simulation results were output in the study area, San Antonio River Basin downstream from San Antonio, Texas, 2000-12.

[SAR, San Antonio River; USGS, U.S. Geological Survey; NWS, National Weather Service; AFB, Air Force Base; --, not applicable; WWTP, wastewater treatment plant]

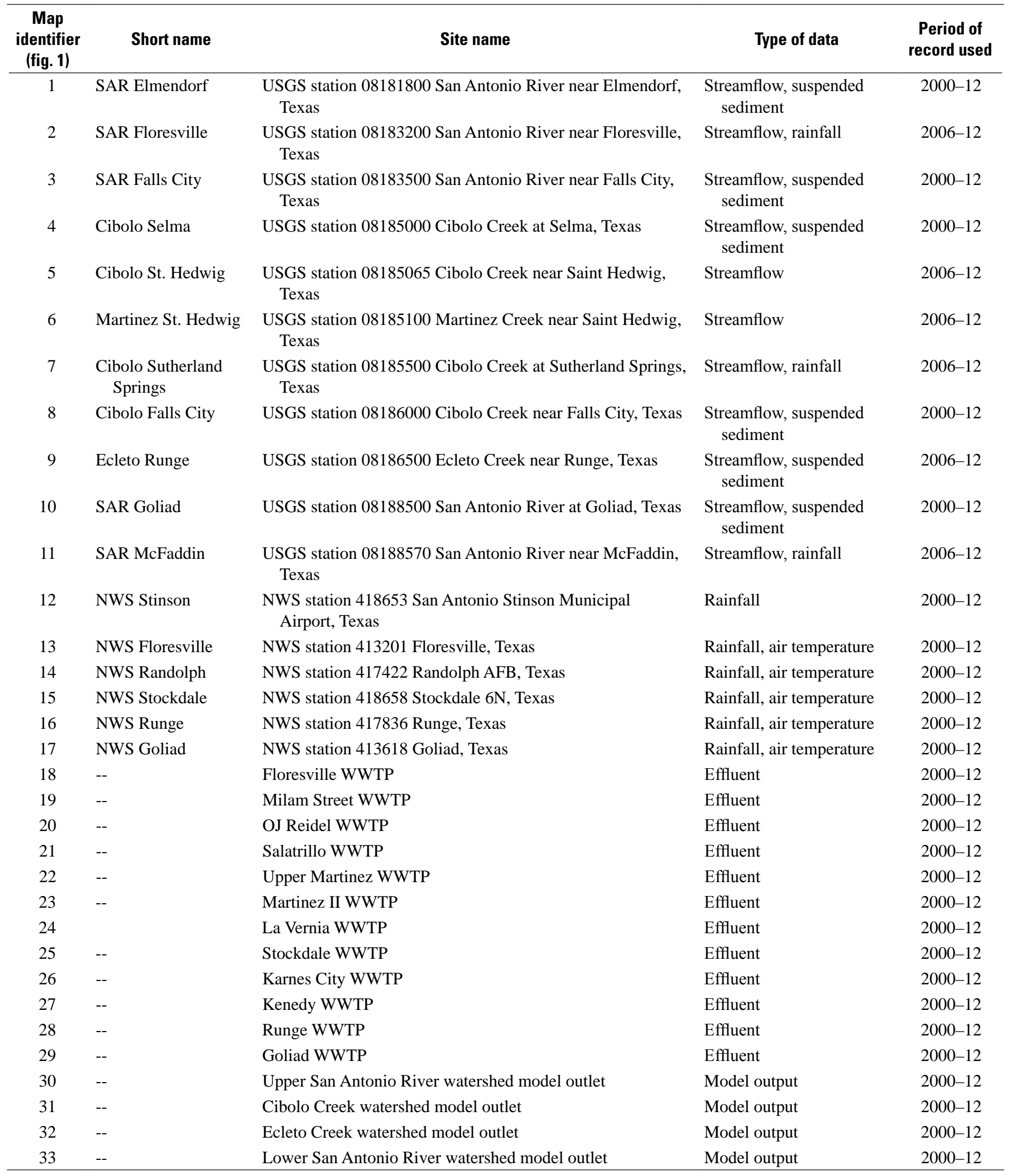


In 2010, the USGS, in cooperation with the San Antonio River Authority, the Evergreen Underground Water Conservation District, and the Goliad County Groundwater Conservation District, developed an HSPF model for the part of the San Antonio River Basin that is downstream from San Antonio, hereinafter referred to as the "USGS-2010 model" (Lizárraga and Ockerman, 2010). The purpose of the model was to provide a better understanding of the hydrologic conditions in the San Antonio River Basin. The USGS2010 model simulated hydrologic conditions (streamflow, evapotranspiration, and groundwater recharge) during 2000-2007. In addition, the USGS-2010 model was designed to accommodate future modifications, such as the addition of model components to simulate various water-quality constituents.

In 2012, URS Corporation developed an updated version of the San Antonio River Basin HSPF model based on the USGS-2010 model (URS Corporation, 2012) (hereinafter referred to as the "URS-2012 model"). The URS-2012 model was calibrated by using available data for 2000-10. Changes to the USGS-2010 model included extending the model simulation period of 2000-2007 to 2000-10, updating input time-series data to include 2008-10, updating land-cover information (previously based on 2001 National Land Cover Database [NLCD]) with data from the 2006 NLCD (MultiResolution Land Characteristics Consortium, 2013), and reconfiguring subwatersheds and stream reaches for increased spatial resolution.

As part of the USGS "Strategic Directions for U.S. Geological Survey Water Science, 2012-2022,” one of the identified priorities was to use USGS "core capabilities in water science" to "conduct, research, and modeling" in support of various goals (Evenson and others, 2012, p. 1, 2). One goal was the "development and application of models to predict potential changes in population, land use, climate, and management practices upon future water availability" (Evenson and others, 2012, p. 17). Hence, to simulate hydrologic conditions and suspended-sediment loads in the San Antonio River Basin during 2000-12, the USGS, in cooperation with the San Antonio River Authority, developed an HSPF model based on the URS-2012 model and the USGS sediment characterization study (Crow and others, 2014). The model documented by this report is hereinafter referred to as the "USGS-2014 model."

\section{Purpose and Scope}

The purpose of this report is to describe the simulation of hydrologic conditions and suspended-sediment loads in the San Antonio River Basin, downstream from San Antonio during 2000-12 by using an HSPF model. The USGS-2014 model was composed of four watershed models that represent the overall study area in the San Antonio River Basin. The functionality of the USGS-2014 model is described, followed by the model development, calibration, and sensitivity analysis. The hydrologic conditions and suspended-sediment loads in the four watersheds in the San Antonio River Basin are summarized. Limitations of modelsimulated hydrologic conditions and suspended-sediment loads are described. Selected sections in this report are modified from Lizárraga and Ockerman (2010), Ockerman and others (2013), or Crow and others (2014).

\section{Description of the Study Area}

The study area and discussion pertaining to the study area are modified from Crow and others (2014), which characterized sediment concentrations and loads in the San Antonio River Basin downstream from San Antonio, Tex. The study area (fig. 1) is part of the San Antonio River Basin and consists of approximately 2,150 square miles $\left(\mathrm{mi}^{2}\right)$ encompassing parts of Bexar, Guadalupe, Wilson, Karnes, DeWitt, Goliad, Victoria, and Refugio Counties. The upstream boundary of the study area coincides with USGS streamflow-gaging station 08181800 San Antonio River near Elmendorf, Tex. (hereinafter referred to as the "SAR Elmendorf gage") and USGS streamflow-gaging station 08185000 Cibolo Creek at Selma, Tex. (hereinafter referred to as the "Cibolo Selma gage") (fig. 1, table 1) (in this report, each gage is referred to by its short name [table 1]). Upstream from the study area, the San Antonio River Basin consists of 1,743 $\mathrm{mi}^{2}$ upstream from the SAR Elmendorf gage and $274 \mathrm{mi}^{2}$ upstream from the Cibolo Selma gage (streamflow and suspended-sediment loads at both gages were considered inputs to the study area). The downstream boundary of the study area is the San Antonio River confluence with the Guadalupe River (fig. 1).

The San Antonio River extends about 190 river miles (mi) in the study area from the SAR Elmendorf gage to the confluence with the Guadalupe River. From the upstream boundary of the study area at the Cibolo Selma gage, Cibolo Creek extends about 75 river mi downstream to the confluence with the San Antonio River in Karnes County. Ecleto Creek extends about 55 river mi from northern Wilson County to the confluence with the San Antonio River in Karnes County (fig. 1). 
The northern part of the study area overlies the EdwardsTrinity aquifer system (fig. 2). The remainder of the study area overlies the Texas Coastal Uplands and Texas Coastal Lowlands aquifer systems (Ryder, 1996). The Cretaceousage rocks of the Edwards-Trinity aquifer system primarily consist of limestone and sandstone (Ashworth and Hopkins, 1995) (fig. 2). The Tertiary-age rocks of the Texas Coastal Uplands aquifer system is primarily composed of formations of the Midway Group through Whitsett Formation, with the sediments distributed as relatively uniform sequences of predominantly fine- or course-grained material (Ryder, 1996). The Tertiary- and Quaternary-age rocks of the Texas Coastal Lowlands aquifer system is primarily composed of formations of Catahoula Formation through Deweyville Formation that dip and thicken towards the Gulf of Mexico, with sediments that exist in complex, overlapping mixtures of sand, silt, and clay as a result of numerous oscillations of ancient shorelines (Kasmarek and Robinson, 2004; Lizárraga and Ockerman, 2010). Previous studies have indicated that the upper part of the study area exhibits significant streamflow gains and losses, which might be attributed to soil types (Lizárraga and Wehmeyer, 2012). County soils data (Soil Survey Geographic database [SSURGO]) indicate that relative infiltration rates in the study area range from "rapid to very rapid" (for example, where the surface geology is characterized as the Carrizo Sand) to "slow to very slow" in other parts of the study area (Natural Resources Conservation Service, 2013) (figs. 2 and 3).

In addition to geology and soil types, land cover and topography can affect hydrologic conditions and sediment loads in the study area. The land-cover composition consists of forest (8.3 percent), rangeland and shrubland (36.3 percent), pasture (35.4 percent), developed and open space (8.1 percent), cropland (7.6 percent), and water and wetlands (4.4 percent) (Multi-Resolution Land Characteristics Consortium, 2013) (fig. 4, table 2). The study area is composed of gently sloping, rolling terrain; the coastal uplands are somewhat more dissected and rolling compared to the coastal lowlands (Ryder, 1996). Elevation in the study area ranges from about 2 feet (ft) to $1,033 \mathrm{ft}$ above North American Vertical Datum of 1988 (NAVD 88) (U.S. Geological Survey, 2014a). The slope of the land surface is generally low, mostly less than 5 percent. Overall, the stream-channel slope of the San Antonio River is about 2 feet per mile (ft/mi) over approximately $190 \mathrm{mi}$ from the model boundary at the SAR Elmendorf gage to the confluence with the Guadalupe River.

\section{Simulation of the Hydrologic Conditions and Suspended-Sediment Loads}

The text in this section and the model description were modified from Ockerman and others (2013). Hydrologic conditions and suspended-sediment concentrations and loads were simulated by using a Hydrological Simulation Program-FORTRAN (HSPF) model (Bicknell and others, 2001). The HSPF model is one of the most comprehensive watershed models, can simulate a variety of stream and watershed conditions with reasonable accuracy, and enables flexibility in adjusting the model to simulate alternative conditions or scenarios (Donigian and others, 1995). Previous HSPF models of the lower San Antonio River (Lizárraga and Ockerman, 2010; URS Corporation, 2012) were available and were modified to simulate hydrologic conditions and sediment transport for this study.

To simulate the watershed hydrologic and sediment processes, different data sources are used as input to the HSPF model including rainfall data, potential evapotranspiration, streamflow data, land cover, and soil characteristics. The outputs of an HSPF model are simulated time series of streamflow and other hydrologic conditions such as evapotranspiration (ET) and groundwater recharge, as well as sediment concentrations, sediment loads, or both. The model time series are for a user-specified interval, or time step. A 1-hour time step was used for this study.

The HSPF model also can simulate other water-quality constituents, including nutrients, metals, and organic compounds. Simulations for this study were limited to hydrologic processes (streamflow, ET, and groundwater recharge) and suspended-sediment concentrations and loads.

\section{Functional Description of Hydrological Simulation Program-FORTRAN}

The HSPF model uses a continuous, semilumped parameter design (Singh, 1995) that can provide continuous water and mass balance by tracking rainfall and waterquality constituents through the conceptual pathways of the hydrologic cycle in a watershed. In HSPF, a watershed is represented by a group of hydrologically distinct areas referred to as "hydrologic response units (HRUs)" that drain to a stream segment, lake, or reservoir referred to as a "reach reservoir (RCHRES)." HRUs are areas in a subwatershed that have distinct hydrologic and water-quality characteristics that are determined on the basis of land use, surficial geology, and other factors that are deemed to produce similar hydrologic responses to rainfall and potential evapotranspiration. HRUs are categorized as pervious or impervious land segments, termed pervious land (PERLND) or impervious land (IMPLND), respectively. A PERLND is represented conceptually within HSPF by three interconnected water-storage zones - an upper zone, a lower zone, and a groundwater zone. An IMPLND is represented by a surface storage zone, subject to evaporation and runoff processes. Each RCHRES is associated with a particular drainage area, referred to as a "subwatershed," and receives the runoff and sediment from the PERLNDs and IMPLNDs in the subwatershed. The hydraulics of a RCHRES are simulated by a storage routing method (Donigian and others, 1995). 


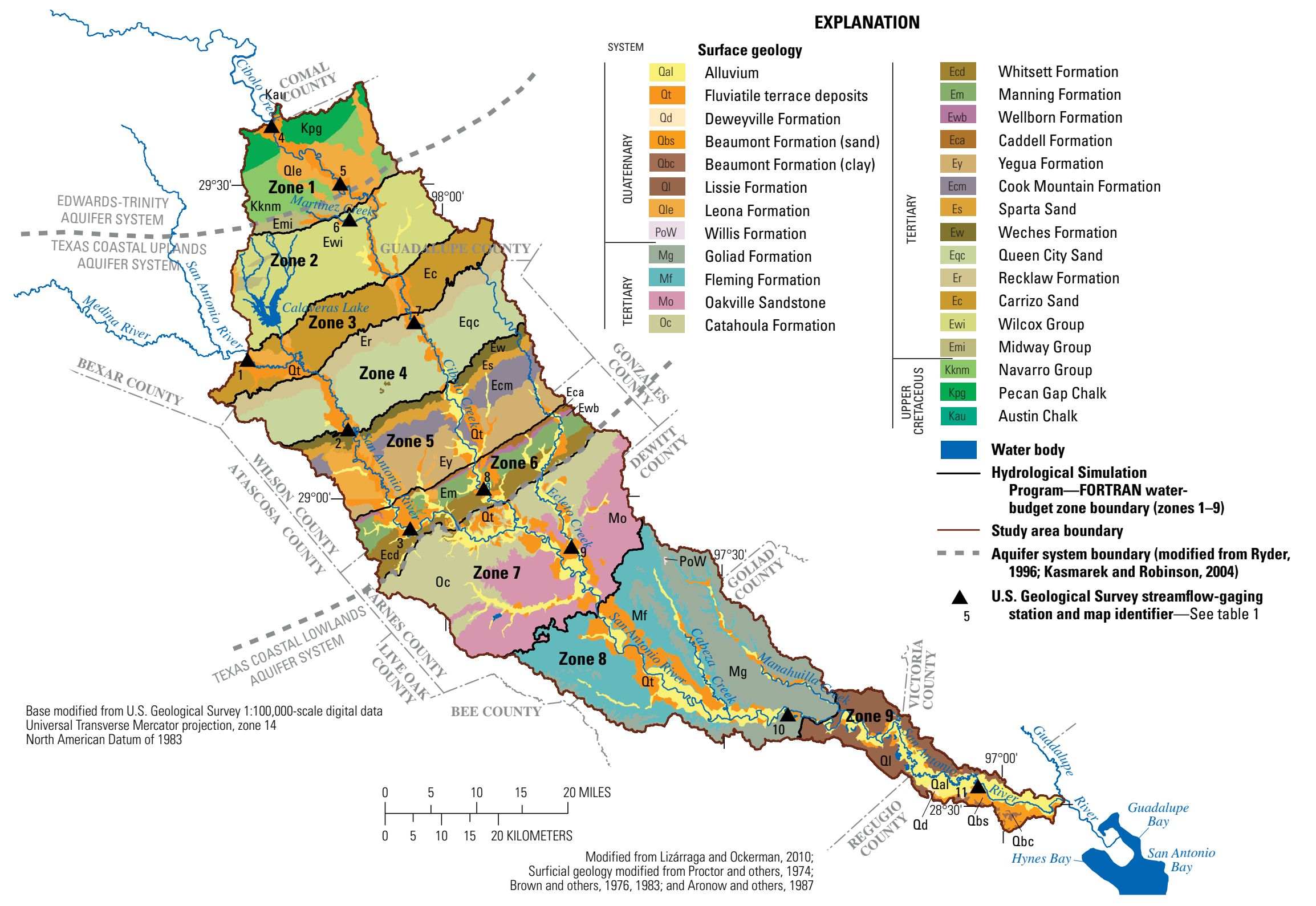

Figure 2. Surface geology in the study area, San Antonio River Basin downstream from San Antonio, Texas. 


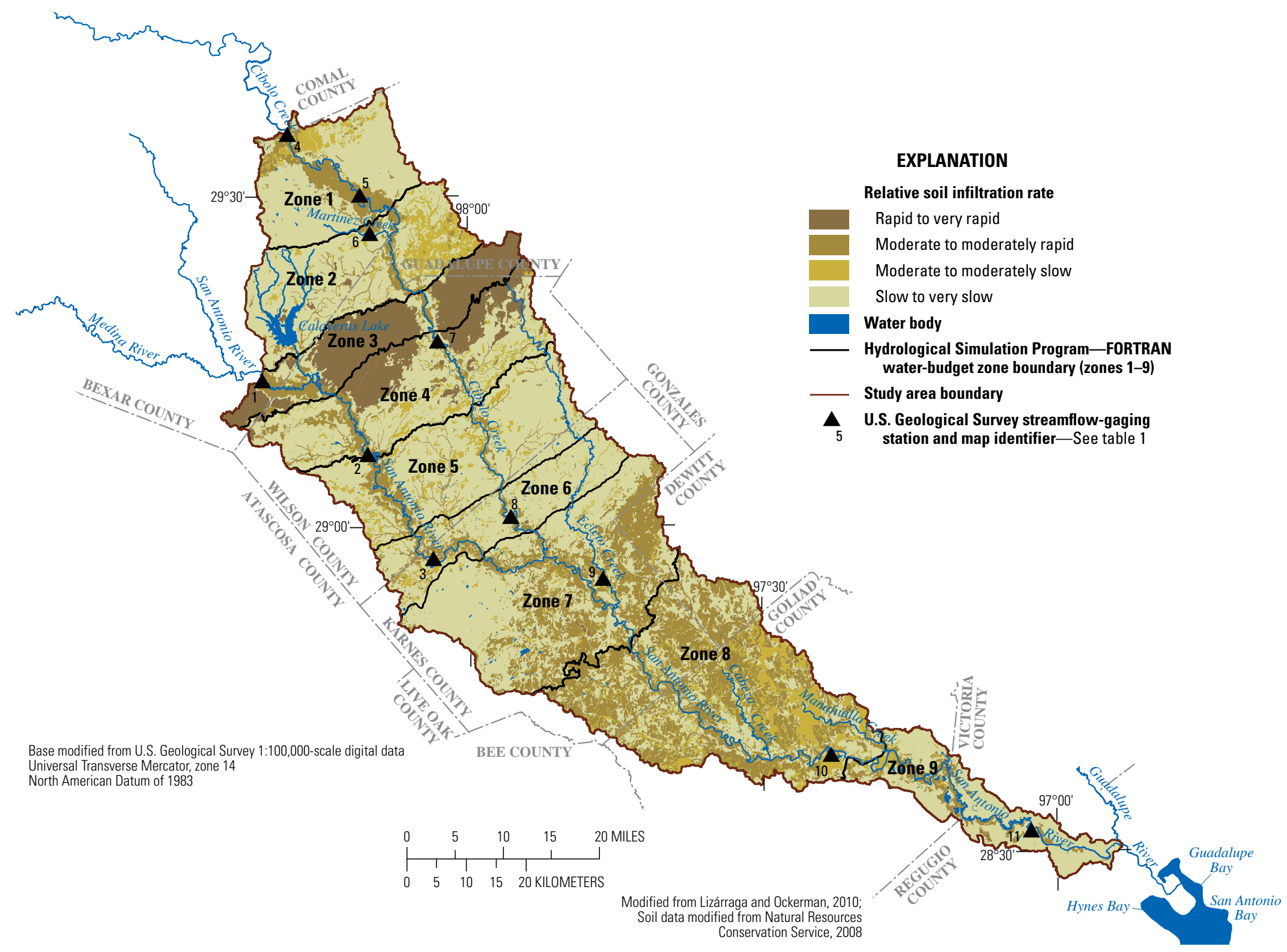

Figure 3. Relative soil infiltration rates in the study area, San Antonio River Basin downstream from San Antonio, Texas. 


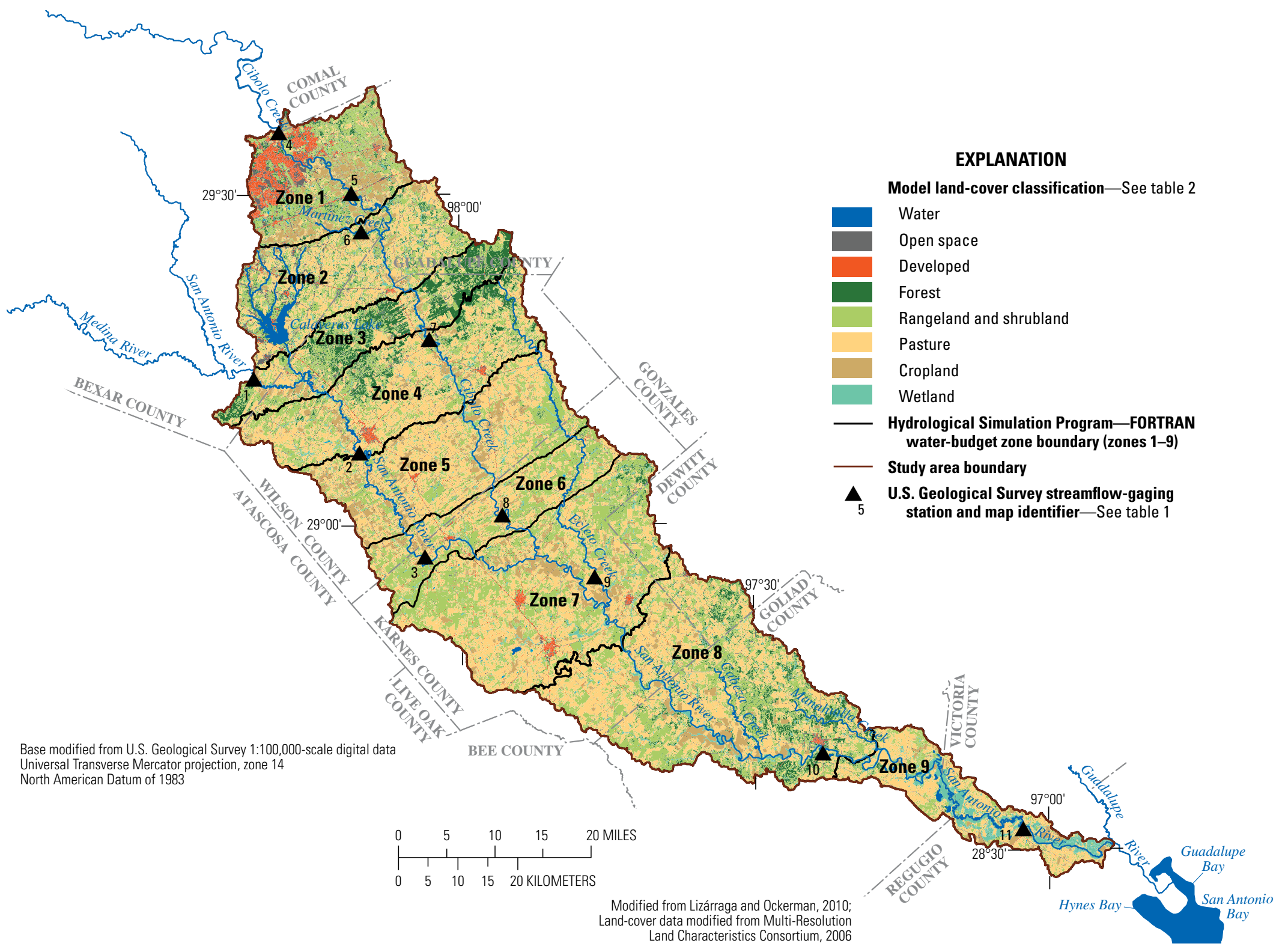

Figure 4. Land-cover classification in the study area, San Antonio River Basin downstream from San Antonio, Texas. 
Table 2. National Land Cover Dataset categories and percent coverage in the study area, San Antonio River Basin downstream from San Antonio, Texas.

[NLCD, National Land Cover Dataset; HSPF, Hydrological Simulation Program—FORTRAN]

\begin{tabular}{cllrc}
\hline $\begin{array}{c}\text { NLCD } \\
\text { code }\end{array}$ & \multicolumn{1}{c}{ NLCD classification } & \multicolumn{1}{c}{$\begin{array}{c}\text { HSPF model } \\
\text { classification }\end{array}$} & $\begin{array}{c}\text { Square } \\
\text { miles }\end{array}$ & $\begin{array}{c}\text { Land cover } \\
\text { (percent) }\end{array}$ \\
\hline 11 & Open water & Water & 11.3 & 0.5 \\
21 & Developed, open space & Open space & 110.4 & 5.1 \\
31 & Barren land (rock/sand/clay) & Open space & 7.8 & 0.4 \\
22 & Developed, low intensity & Developed & 38.9 & 1.8 \\
23 & Developed, medium intensity & Developed & 12.6 & 0.6 \\
24 & Developed, high intensity & Developed & 3.6 & 0.2 \\
41 & Deciduous forest & Forest & 152.2 & 7.1 \\
42 & Evergreen forest & Forest & 14.0 & 0.7 \\
43 & Mixed forest & Forest & 9.8 & 0.5 \\
52 & Shrub/scrub & Rangeland/shrubland & 688.9 & 32.0 \\
71 & Grassland/herbaceous & Rangeland/shrubland & 91.9 & 4.3 \\
81 & Pasture/hay & Pasture & 762.1 & 35.4 \\
82 & Cultivated crops & Cropland & 163.1 & 7.6 \\
90 & Woody wetlands & Wetland & 75.4 & 3.5 \\
95 & Emergent herbaceous wetlands & Wetland & 8.4 & 0.4 \\
\hline
\end{tabular}

${ }^{1}$ Land-cover percentages do not sum to 100 percent because of rounding.

The HSPF model is composed of a series of computational routines that simulate processes of the hydrologic cycle. Specifically, HSPF simulates the hydrologic cycle as an interconnected series of storage (and processing) segments with water fluxes (volume per unit area per unit time) and constituent fluxes (mass [weight] per unit area per unit time) moving between the various storages. A flowchart of HSPF hydrologic processes for IMPLNDs and PERLNDs is shown on figure 5. A flowchart of HSPF sediment processes for IMPLNDs, PERLNDs, and RCHRESs is shown on figure 6 . The movement of water and suspended sediment from IMPLNDs and PERLNDs and between storage zones is controlled by various process-related parameters. Although some parameters are directly measurable, most are determined during model calibration (Martin and others, 2001). The definitions of selected HSPF model process parameters used in the study area are listed in appendix 1. A complete description of the computational processes and required input model parameters is provided in the HSPF user's manual (Bicknell and others, 2001).
The suspended-sediment concentrations and loads were simulated by using the appropriate HSPF modules: SEDMNT for simulation of production and removal of sediment from PERLNDs, SOLIDS for simulation of accumulation and removal of solids from IMPLNDs, and SEDTRN for simulation of transport of sediment in RCHRESs. For each PERLND, the processes of detachment of sediment from the soil matrix and washoff of this sediment were simulated on the basis of rainfall intensity, surface runoff, and model parameters that control the accumulation, detachment, and transport of soils. For each IMPLND, the processes of accumulation and washoff of sediment are based on the amount of sediment available and the transport capacity of the overland flow. Sediment transport processes in a RCHRES included deposition and scour, which are functions of sediment size, settling velocity, density, erodibility, bed depth, and critical shear stress. Sediment transport for RCHRESs is computed separately for each sand, silt, and clay fraction of sediment size. 
A. Impervious land segments

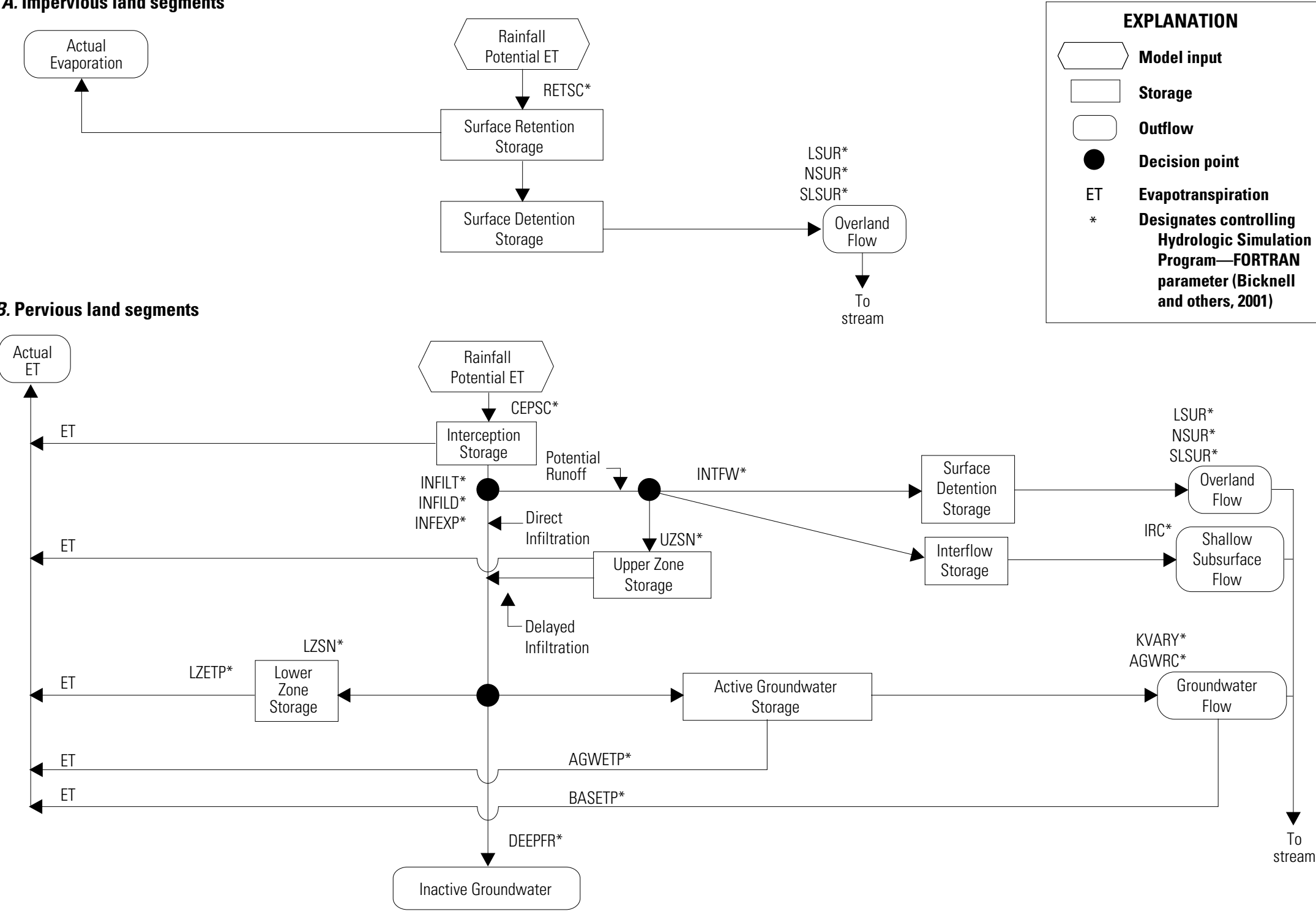

Modified from Lizárraga and Ockerman, 2010

Figure 5. Hydrological Simulation Program—FORTRAN (HSPF) flowchart for hydrologic processes on $A$, impervious land segments and $B$, pervious land segments (modified from Ockerman and others, 2013). 
A. Impervious land segments
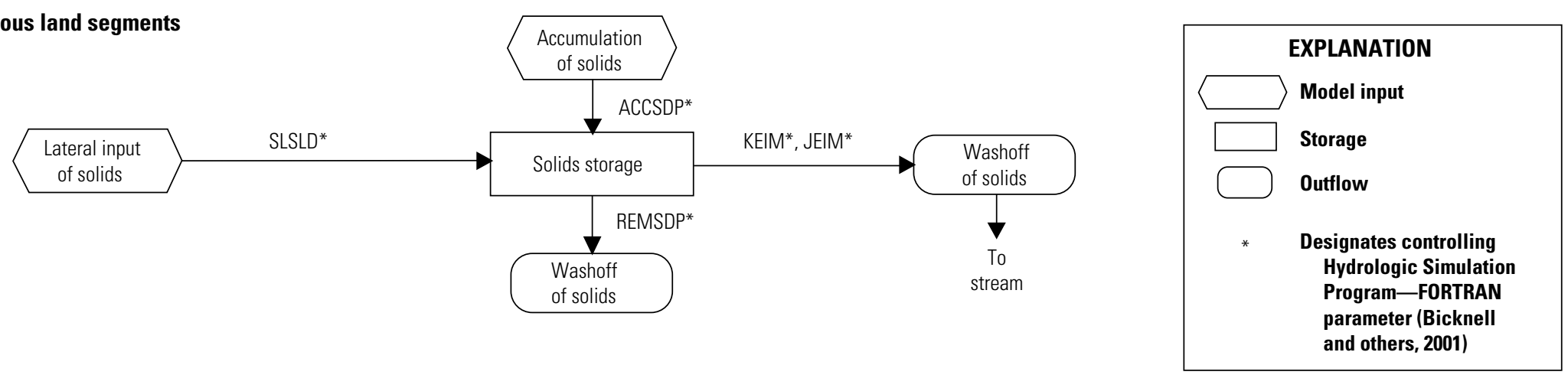

B. Pervious land segments

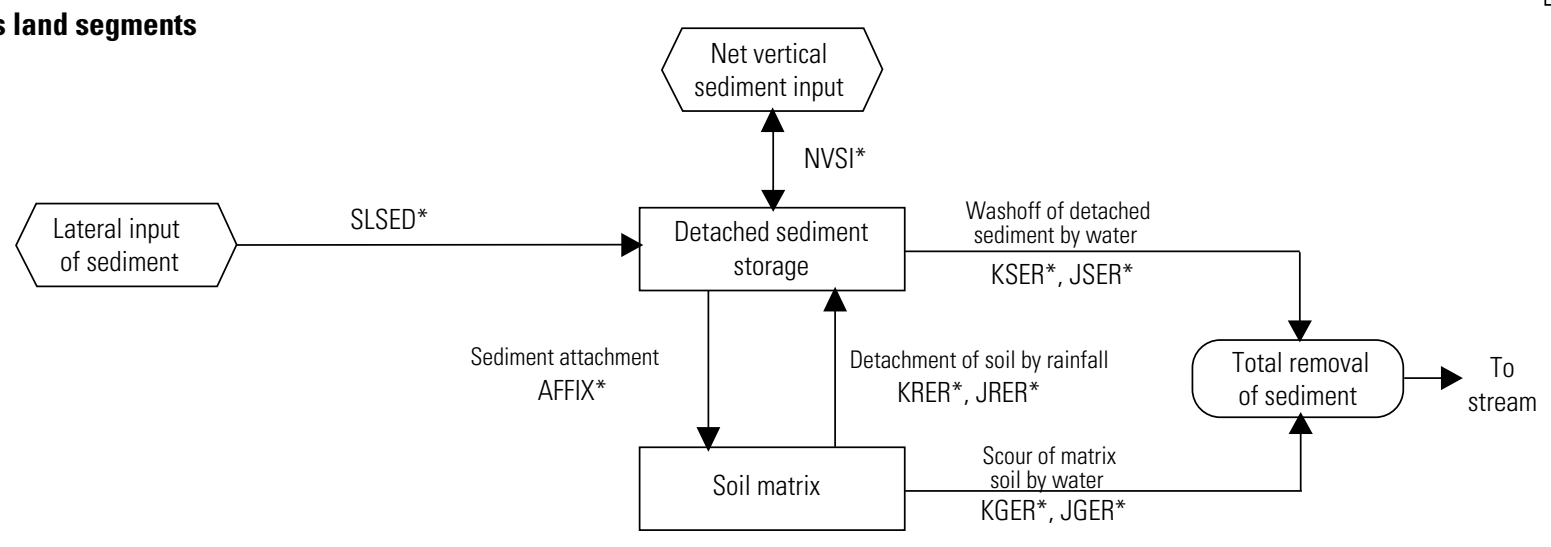

\section{Stream reaches}

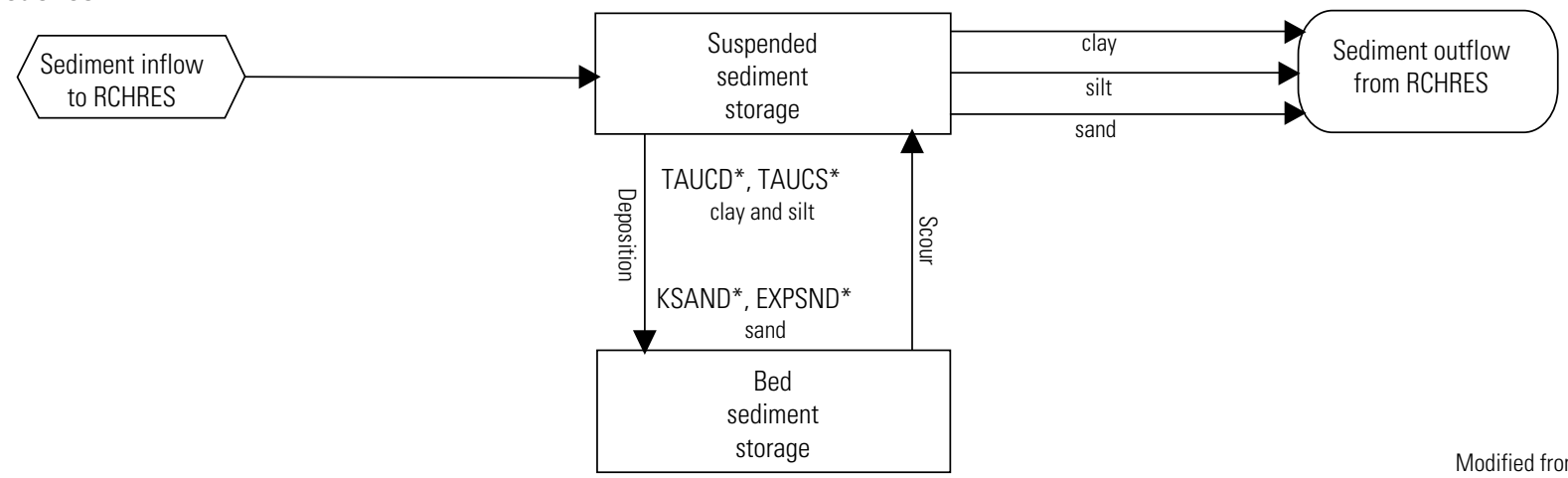

Modified from Ockerman and others, 2013

Figure 6. Hydrological Simulation Program—FORTRAN (HSPF) flowchart for sediment processes on $A$, impervious land segments; $B$, pervious land segments; and $C$, stream reaches (modified from Ockerman and others, 2013). 


\section{Model Development}

The USGS-2014 model was developed by (1) configuring the model to represent the study area in the San Antonio River Basin and (2) compiling and processing required meteorological, streamflow, and sediment input data. The USGS-2014 model was configured by defining model watersheds (including subwatersheds and HRUs), waterbudget zones, and RCHRES segments for the study area on the basis of surficial geology, land cover, and location of meteorological stations. Because of the relatively large size of the study area, the study area in the USGS-2014 model was divided into four watersheds, each with an associated HSPF model (fig. 7): (1) San Antonio River upstream from Cibolo Creek, hereinafter referred to as the "upper SAR model"; (2) Cibolo Creek, hereinafter referred to as the "Cibolo model"; (3) Ecleto Creek, hereinafter referred to as the "Ecleto model"; and (4) San Antonio River downstream from Cibolo Creek, hereinafter referred to as the "lower SAR model."

\section{Model Configuration}

The upper SAR model includes the drainage area extending from the upstream model boundary at the SAR Elmendorf gage to the confluence of the San Antonio River and Cibolo Creek. The Cibolo model includes the drainage area from the Cibolo Selma gage to the confluence of Cibolo Creek and the San Antonio River. The Ecleto model includes the entire Ecleto Creek watershed, upstream from the confluence of Ecleto Creek and the San Antonio River. The lower SAR model includes the drainage area extending from the confluence of the San Antonio River and Cibolo Creek to the confluence of the San Antonio and Guadalupe Rivers, excluding the Ecleto Creek watershed. The most downstream watershed model (lower SAR model) receives as input the simulated streamflow and sediment from the outlets of the three other HSPF models. A simulation of the overall study area involves running simulations of the three upstream watershed HSPF models, then running the lower SAR model.

The drainage areas of each of the four watershed models (upper SAR, Cibolo, Ecleto, and lower SAR models) were further divided into subwatersheds, with associated stream reaches (RCHRESs). Considerations in delineating the subwatersheds and stream reaches included (1) defining reaches with streamflows such that travel times through RCHRESs approximate the model simulation time step and (2) locating outlets of RCHRESs at strategic points, such as streamflow-gaging stations, tributary confluences, and geologic outcrop boundaries (Donigian and others, 1984).

The USGS-2010 model (Lizárraga and Ockerman, 2010) included 162 subwatersheds with an average size of $13.3 \mathrm{mi}^{2}$. The URS-2012 model revised the subwatershed and stream reach delineation, increasing the spatial resolution of the model(s) to include a total of 339 subwatersheds (and associated RCHRESs) with an average size of $6.3 \mathrm{mi}^{2}$ (URS Corporation, 2012). The URS-2012 model stream delineation was adopted for use in this modeling study and further modified by the addition of a single subwatershed at the most downstream boundary of the model, at the confluence of the San Antonio and Guadalupe Rivers. The subwatershed and stream-reach delineation is shown in figure 7. Each subwatershed is further subdivided into PERLND and IMPLND HRUs based on surficial geology, land-cover type, and source of input meteorological data.

The model(s) configuration also included the delineation of nine water-budget zones, determined on the basis of surficial geology, as shown in figure 2 . For each zone, model outputs were created to be able to provide simulation results of water-budget information (runoff, evapotranspiration, and groundwater recharge).

The hydraulic response of each RCHRES was simulated based on channel geometry (channel width and depth, and stream discharge as a function of water volume in the RCHRES) (Bicknell and others, 2001). For RCHRESs that included a USGS streamflow-gaging station, channelgeometry and stream discharge data (depth and width for a range of stream discharge conditions) were based on available USGS measurement data collected at the station (U.S. Geological Survey, 2014b). Channel depth and width values measured at a USGS streamflow-gaging station were assumed constant for the entire reach length to calculate RCHRES surface area and water volume associated with a measured stream discharge. For ungaged RCHRESs, where channel geometry data were not available, the channel depths and widths were assumed to be similar as nearby gaged RCHRESs, for the same stream discharge. During model calibration, the hydraulic characteristics for selected RCHRESs were adjusted to improve model fit.

\section{Input Data for the Hydrological Simulation Program-FORTRAN Model}

Input data for the HSPF model included spatial and time-series data. Spatial data included geology, soils, landcover, topography, and drainage characteristics such as subwatershed boundaries and stream-reach length and crosssection data. Spatial data were used to define and configure model subwatersheds, water-budget zones, RCHRESs, and HRUs (PERLNDs and IMPLNDs). Time-series data included meteorological data (rainfall and potential evapotranspiration), streamflow data, and suspended-sediment load data.

Meteorological time-series data were used to drive the model simulation. Streamflow and suspended-sediment time-series data generally were used as input data at the upstream model boundaries and also used to calibrate and test the model at selected locations in the model study area. 


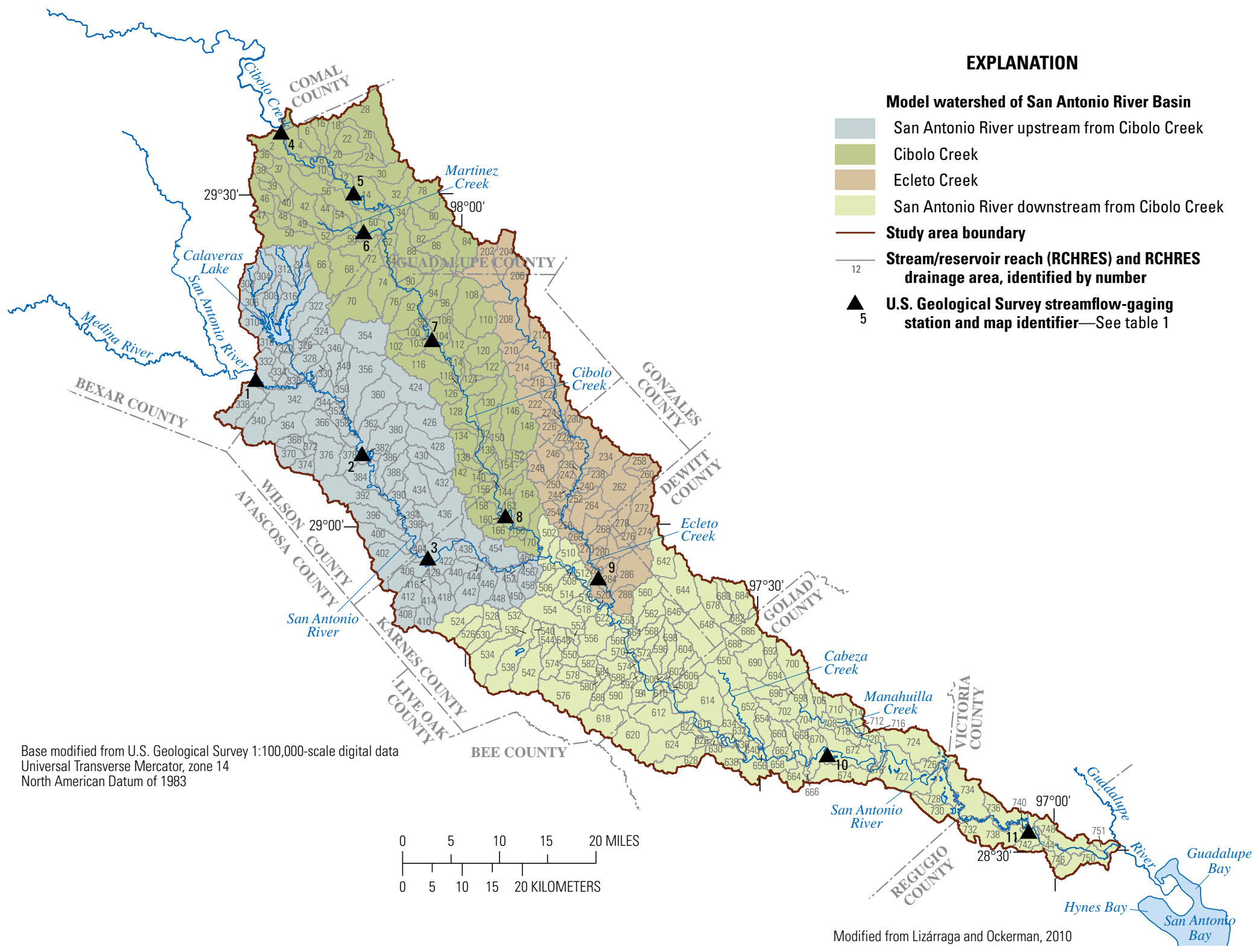

Figure 7. Watershed and stream/reservoir reach delineation for the Hydrological Simulation Program—FORTRAN model of the study area, San Antonio River Basin downstream from San Antonio, Texas. 


\section{Spatial Data}

Surficial geology data (fig. 2) were obtained from four areal geologic maps published in the Geologic Atlas of Texas by the University of Texas Bureau of Economic Geology: Beeville-Bay City sheet (Aronow and others, 1987), Crystal City-Eagle Pass sheet (Brown and others, 1976), Seguin sheet (Proctor and others, 1974), and San Antonio sheet (Brown and others, 1983). The surficial geology data were used to help classify HRU types and to define general geologic outcrop areas, referred to in this report as "water-budget zones" (fig. 2). The HSPF model outputs were created for each of the water-budget zones to evaluate simulated hydrologic conditions by zone and by watershed.

County soils data (Soil Survey Geographic database [SSURGO]) from the Natural Resources Conservation Service (2013) were compiled for the study area. Soils data were not used explicitly to define PERLND types. Instead, soil attributes of relative infiltration and erodibility were used to determine selection of initial values for the HSPF parameters of soil-infiltration rate (INFILT) and soil erodibility/ detachability (KRER).

The USGS-2010 model used the 2001 National Land Cover Database (NLCD) (Homer, and others, 2007) as the source for land-cover data. The URS-2012 model (URS Corporation, 2012) incorporated the 2006 NLCD (Fry and others, 2011). The 2006 NLCD data also were used for the USGS-2014 version of the model. In the study area, there were 15 NLCD land-cover classes. To simplify the model configuration, the 15 classes were reclassified into eight landcover categories (fig. 4, table 2). The area of each land-cover type and percent coverage of the study area are also listed in table 2. Developed land was principally classified as lowintensity development, of which 25 percent was simulated as impervious area. Barren land was a small percentage of the study area ( 0.4 percent) and was grouped with developed open space, and the resulting acreage was considered to be 15 percent impervious (Multi-Resolution Land Characteristics Consortium, 2013). Areas classified as open water were not part of a PERLND or IMPLND HRU; these areas were modeled as part of the stream RCHRESs. Digital elevation data for the study area were obtained from the USGS National Elevation Dataset (U.S. Geological Survey, 2014a). The digital elevation data were used to delineate subwatersheds as part of the HSPF model development. Spatial data for streams (location and reach length) were obtained from the National Hydrography Dataset (U.S. Geological Survey, 2014c).

\section{Meteorological Data}

Daily precipitation totals and daily maximum and minimum temperatures used as input for the models were obtained from the DAYMET climate database, distributed through the Oak Ridge National Laboratory Distributed Active Archive Center (Thornton and others, 2012). DAYMET algorithms and computer software are designed to interpolate and extrapolate from observed daily meteorological observations to produce gridded values of daily precipitation and maximum and minimum temperature on a 1 kilometer $(\mathrm{km}) \times 1 \mathrm{~km}$ gridded surface over the conterminous United States, Mexico, and Southern Canada. These data have an advantage of using consistent calculation methodology and data gap filling, which are often problematic when using discrete National Weather Service (NWS) or USGS rainfall gage data. To maintain a consistent meteorological input configuration as the earlier versions of the models, DAYMET data were obtained from the five NWS meteorological stations in the model study area (fig. 1, table 1). Besides daily rainfall from the DAYMET locations, available hourly rainfall data from the NWS station 417422 Randolph Air Force Base, Tex. (hereinafter referred to as the "NWS Randolph station"), also were compiled for use with the model simulations (National Oceanic and Atmospheric Administration, 2013). Consistent with the URS-2012 model, rainfall was spatially distributed between watershed models using the Thiessen method (Linsley and others, 1982). Each Thiessen area (polygon) was named for the NWS station in that polygon (fig. 8, table 1). Because the HSPF models were designed to simulate on an hourly time step, DAYMET daily precipitation totals from four precipitation stations were disaggregated to hourly totals based on the temporal distribution of rainfall measured at one or more nearby meteorological stations in the study area (NWS station 418653 Stinson San Antonio Municipal Airport, Tex. [hereinafter referred to as the "NWS Stinson station"], the NWS Randolph station, and three USGS rainfall stations colocated with USGS streamflow-gaging stations: SAR Floresville, Cibolo Sutherland Springs, SAR McFaddin) (fig. 1, table 1).

USGS rainfall gages in the study area were calibrated to provide 15-minute rainfall data (U.S. Geological Survey, 2009), and when aggregated to hourly totals, were considered reliable temporal precipitation records that could be used for disaggregating the DAYMET daily rainfall totals to hourly totals. If hourly rainfall data were not available from the nearby meteorological stations, hourly values were obtained by using a triangular distribution of the daily rainfall value with a peak at the middle of the day (Hummel and others, 2001). Disaggregation of daily rainfall data was performed through the WDMUtil program, a utility program that is part of the Better Assessment Science Integrating Point and Nonpoint Sources (BASINS) software package (version 4.0) provided by the U.S. Environmental Protection Agency (EPA), and used to run the HSPF model (U.S. Environmental Protection Agency, 2013). Hourly data from the NWS Randolph station were used directly for model simulations. DAYMET annual rainfall for 2000-12 (Thornton and others, 2012) at the locations of the five NWS stations in the study area ranged from 13.8 inches in 2008 (NWS Randolph) to 54.9 inches in 2007 (NWS station 418658 Stockdale 6N, Tex. [hereinafter referred to as the "NWS Stockdale station"]), with an average rainfall of approximately 33 inches per year. 


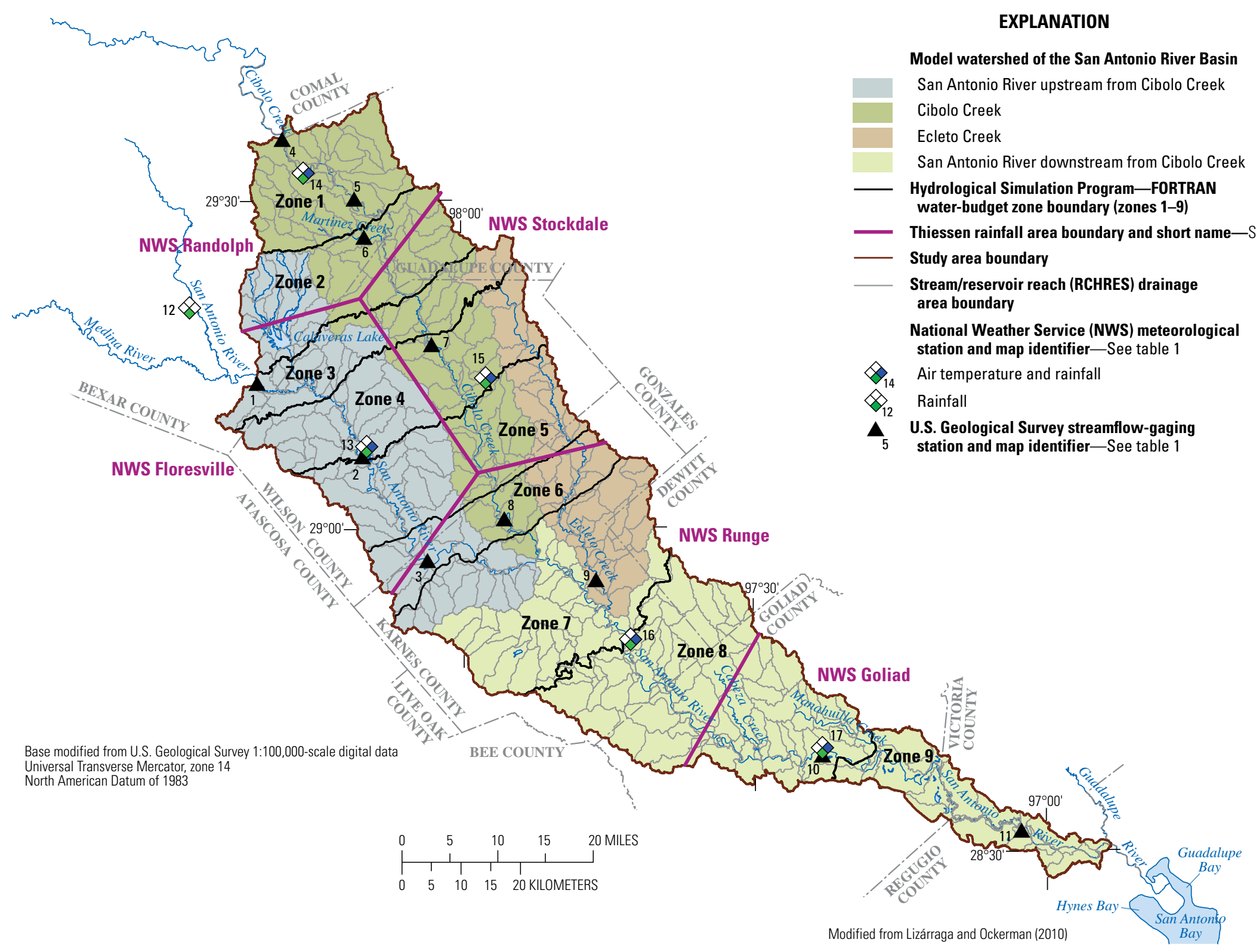

Figure 8. Location of National Weather Service meteorological stations and associated Thiessen rainfall areas in the study area, San Antonio River Basin downstream from San Antonio, Texas. 
DAYMET daily maximum and minimum temperature data were used to calculate daily potential evapotranspiration at the five NWS stations located in the study area. The Hamon method (Bidlake, 2002) was used to calculate daily potential evapotranspiration from minimum and maximum daily temperatures by using the EPA BASINS 4.0 software (U.S. Environmental Protection Agency, 2013). Daily potential evapotranspiration was converted to hourly time series by using the disaggregation algorithms in the BASINS 4.0 software (U.S. Environmental Protection Agency, 2013). Daily potential evaporation is disaggregated on the basis of latitude and time of year (Hummel and others, 2001).

\section{Streamflow Data}

As stated in the Description of the Study Area section of this report, most of the streamflow in the study area originates upstream from the study area. These inflows are measured at the SAR Elmendorf and Cibolo Selma gages (fig. 1, table 1), which account for streamflow into the model area (U.S. Geological Survey, 2014b). Other USGS streamflow-gaging stations in the study area provided data that were used for calibration and testing of the model simulations. Location information, type of data collected, and period of record for gages that provided streamflow data for the model are listed in table 1 . The streamflow data used for this report are available from the USGS National Water Information System (NWISWeb) (U.S. Geological Survey, 2014b).

Wastewater discharges upstream from the study area have an appreciable effect on streamflow in the San Antonio River. Simulated treated wastewater accounted for about 20 percent of the San Antonio River annual mean streamflow entering the study area upstream from the SAR Elmendorf gage during 1997-2001 (Ockerman and McNamara, 2003). Within the
Cibolo Creek watershed, wastewater from four relatively large treatment plants (OJ Riedel, Salatrillo, Upper Martinez, and Martinez II) flows into Martinez Creek or Cibolo Creek (fig. 1, table 3). Each of the four plants discharges more than 1 million gallons of treated wastewater each day. Monthly mean discharge data from these four plants for 2000-2007 were reported by Lizárraga and Ockerman (2010) and were included as model inputs for the USGS-2010 model. Discharge data were updated through 2012 for this version of the model (Daniel Flores, San Antonio River Authority, written commun., 2013; Douglas Vaughn and Robert Dabney, Cibolo Creek Municipal Authority, written commun., 2013). Monthly discharge totals were disaggregated and input to the model as hourly mean discharges. Locations and daily mean discharge for eight additional smaller wastewater treatment plants (less than 1 million gallons per day) (fig. 1, table 3) were obtained from the U.S. Environmental Protection Agency database (2013).

As described in Lizárraga and Ockerman (2010), inflow to Cibolo Creek from springs upstream from USGS streamflow-gaging station 08185500 Cibolo Creek at Sutherland Springs, Tex. (hereinafter referred to as the "Cibolo Sutherland Springs gage") (fig. 1, table 1), was simulated in the model as a time-series input to stream reaches (RCHRESs) 14, 34, 62, 64, 76, 92, and 98 of the Cibolo Creek model (fig. 7). The time series representing springflow was developed from data collected from streamflow gain-loss measurements during 2006-10 (Lizárraga and Wehmeyer, 2012). Streamflow gains, attributed to springs, were observed from the differences between measurements made at the USGS streamflowgaging station 08185065 Cibolo Creek near St. Hedwig, Tex., (hereinafter referred to as the "Cibolo St. Hedwig gage") and Cibolo Sutherland Springs gage. During four sets of synoptic

Table 3. Wastewater discharges included in the Hydrological Simulation Program—FORTRAN (HSPF) model of the study area, San Antonio River Basin downstream from San Antonio, Texas, 2000-12.

[WWTP, wastewater treatment plant]

\begin{tabular}{cllc}
\hline $\begin{array}{c}\text { Map identifier } \\
\text { (fig. 1) }\end{array}$ & \multicolumn{1}{c}{$\begin{array}{c}\text { Wastewater } \\
\text { treatment plant }\end{array}$} & \multicolumn{1}{c}{ Receiving stream } & $\begin{array}{c}\text { Average discharge } \\
\text { (million gallons per day) }\end{array}$ \\
\hline 18 & Floresville WWTP & San Antonio River upstream from Cibolo Creek & 0.57 \\
19 & Milam Street WWTP & San Antonio River upstream from Cibolo Creek & 0.12 \\
20 & OJ Riedel WWTP & Cibolo Creek & 6.0 \\
21 & Salatrillo WWTP & Martinez Creek & 6.0 \\
22 & Upper Martinez WWTP & Martinez Creek & 2.7 \\
23 & Martinez II WWTP & Martinez Creek & 2.2 \\
24 & La Vernia WWTP & Cibolo Creek & 0.05 \\
25 & Stockdale WWTP & Cibolo Creek & 0.13 \\
26 & Karnes City WWTP & San Antonio River downstream from Cibolo Creek & 0.06 \\
27 & Kenedy WWTP & San Antonio River downstream from Cibolo Creek & 0.99 \\
28 & Runge WWTP & San Antonio River downstream from Cibolo Creek & 0.06 \\
29 & Goliad WWTP & San Antonio River downstream from Cibolo Creek & 0.26 \\
\hline
\end{tabular}


measurements made during base-flow conditions (April 2006, August 2006, February 2007, and October 2007), streamflow gains between the Cibolo St. Hedwig and Cibolo Sutherland Springs gages ranged between 4.8 and 29 cubic feet per second $\left(\mathrm{ft}^{3} / \mathrm{s}\right.$ ) (Lizárraga and Wehmeyer, 2012). To develop a continuous daily time series of springflow for input to the model, the observed streamflow gains were related to daily water-level readings at the $\mathrm{J}-17$ index well (Edwards Aquifer Authority, 2014), made on the same day as the streamflow measurements from which the streamflow gains are determined. The J-17 index well (State well number AY-6837-203) (not shown in fig. 1) is located in San Antonio, approximately 27 miles northwest of Sutherland Springs. A regression equation relating measured streamflow gains to J-17 daily water levels (ranging from approximately 635 to 702 feet above the National Geodetic Vertical Datum of 1929 [NGVD 29], Edwards Aquifer Authority, 2014) was developed and used to calculate daily springflow input to Cibolo Creek for 2000-12. The resulting regression equation was

$$
\mathrm{Q}_{\text {springffow }}=2 \times 10^{-77} \times \mathrm{L}^{27.521} \text {, }
$$

where

$\mathrm{Q}_{\text {springfow }}$ is the daily mean spring discharge to Cibolo Creek, in cubic feet per second; and

$\mathrm{L} \quad$ is daily water level of the $\mathrm{J}-17$ well, in feet above NGVD 29.

The coefficient of determination $\left(\mathrm{R}^{2}\right)$ between springflow and the daily water level of the $\mathrm{J}-17$ well was 0.88 .

Monthly surface-water withdrawals for irrigation from the San Antonio River and Cibolo Creek were based on data provided by the Texas Commission on Environmental Quality (TCEQ) (Lizárraga and Ockerman, 2010). The monthly surface-water withdrawals were disaggregated into hourly values. Monthly mean withdrawals for each TCEQ stream reach during 2000-2005 were used to estimate monthly values for the period when withdrawal data were not available (200612). Also, TCEQ-defined stream reaches do not correspond directly with the HSPF RCHRESs; each TCEQ reach typically includes several RCHRESs. Total withdrawals from each TCEQ stream reach were allocated to the appropriate RCHRES in proportion to the amount of cropland included in the area draining to each RCHRES. Cropland acreage was assumed constant for the simulation period, 2000-12.

\section{Estimated Suspended-Sediment Loads}

Estimated suspended-sediment loads at selected stream locations were used (1) to account for sediment inflows at the model upstream boundaries and (2) to provide time-series data for model calibration and testing at selected in-stream locations. The study area, which is in the San Antonio River Basin, receives streamflow and sediment from two upstream watersheds that are not included as part of the model (the inflow from these watersheds is gaged at the SAR Elmendorf and Cibolo Selma gages). To account for these upstream contributions of suspended sediment entering the lower SAR model, estimated suspended-sediment load time series were developed for the SAR Elmendorf and Cibolo Selma gages (fig. 1) to represent inflows to the upstream model boundaries. Similarly, estimated suspended-sediment time-series were developed for the USGS streamflow-gaging station 08183500 San Antonio River near Falls City, Tex., (hereinafter referred to as the "SAR Falls City gage"), the USGS streamflowgaging station 08186000 Cibolo Creek near Falls City, Tex., (hereinafter referred to as the "Cibolo Falls City gage"), the USGS streamflow-gaging station 08186500 Ecleto Creek near Runge, Tex., (hereinafter referred to as the "Ecleto Runge gage"), and the USGS streamflow-gaging station 08188500 San Antonio River at Goliad, Tex., (hereinafter referred to as the "SAR Goliad gage") (fig. 1, table 1). Streamflow data collected at these gages were used as calibration and testing datasets. Time series of the estimated suspended-sediment loads for 2000-12 were developed by using regression equations to estimate suspended-sediment concentration as a function of streamflow (Crow and others, 2014). A regression equation to estimate suspended-sediment concentrations at the Cibolo Selma gage was not developed by Crow and others (2014) because few measurements of suspended-sediment concentration data were available. To represent potential suspended-sediment load input to the USGS-2014 model at the model boundary, a time series of estimated suspendedsediment loads at the Cibolo Selma gage was developed based on a relation between streamflow and three available suspended-sediment concentration samples (hereinafter referred to as "estimated suspended-sediment loads"). The resulting equation (when retransformed, accounting for potential transformation bias; Helsel and Hirsch, 2002) was

$$
\mathrm{SSC}=85.1 \times \mathrm{Q}^{0.208}
$$

where
SSC
is the estimated suspended-sediment concentration, in milligrams per liter, at the Cibolo Selma gage; and
Q is the streamflow, in cubic feet per second.

Annual sediment loads entering the system at the Cibolo Selma gage were highly variable because streamflow is relatively infrequent at this gage. From the suspendedsediment particle size samples collected at the SAR Elmendorf gage, Crow and others (2014) reported a distribution of about 4 percent sand, 23 percent silt, and 73 percent clay. This distribution was used to apportion the estimated sediment loads entering the model study area at the SAR Elmendorf gage between sand, silt, and clay. Analysis of suspendedsediment particle size data at the Cibolo Selma gage indicated a distribution of about 2 percent sand, 19 percent silt, and 79 percent clay (Crow and others, 2014). This distribution was used to apportion the estimated sediment loads entering the model study area at the Cibolo Selma gage between sand, silt, and clay. 


\section{Model Calibration}

The USGS-2014 model was calibrated in two steps. First, the parameters related to hydrologic processes were calibrated. Next, the parameters related to suspended-sediment processes were calibrated. The USGS-2014 model was calibrated by using data collected during 2006-12. After the USGS-2014 model was calibrated, the model was then tested by using data collected during 2000-2005 (not part of the calibration process). The testing period was used to evaluate the ability of the model to accurately simulate hydrologic and suspendedsediment processes within the study area.

\section{Hydrology}

A primary goal of hydrologic model calibration is to adjust process-related parameters such that model-simulated streamflow matches observed streamflow at the USGS streamflow-gaging stations in the study area. In addition, model parameters were set so that the simulated hydrologic conditions, such as evapotranspiration and groundwater recharge rates in study area, were similar to those reported in literature. The model calibrations were evaluated by following guidelines by Donigian and others (1984), Donigian (2002), U.S. Environmental Protection Agency (2000, 2006), and Moriasi and others (2007). These guidelines include comparing observed and simulated results (for example, streamflow volumes), as well as examining model-fit statistics on daily to annual time steps. For example, model calibration is classified as "very good" when the monthly or annual mean streamflow percent difference ([simulated-measured]/ measured $\times 100$ ) is less than 10 percent, "good" when the difference is $10-15$ percent, and "fair" when the difference is 15-25 percent (Moriasi and others, 2007; Donigian, 2002) (table 4). In addition, generation and analysis of model simulation scenarios (GenScn) for watersheds (Kittle and others, 1998) were used to develop model-fit statistics between the observed and simulated hydrologic conditions. Modelfit statistics include (1) $\mathrm{R}^{2}$ of the linear regression between measured and simulated variable (in this section, streamflow); (2) Nash-Sutcliffe coefficient of model-fit efficiency (NSE) (Nash and Sutcliffe, 1970); and (3) root mean squared error (RMSE) to observations standard deviation (SD) ratio, hereinafter referred to as the "RSR." The $\mathrm{R}^{2}$ and NSE describe the variation in the dependent variable that is explained by the independent variable. Donigian (2002) also provides a continuum of $\mathrm{R}^{2}$ values for evaluating the simulation of daily mean streamflow. For this report, simulated mean streamflow with an $\mathrm{R}^{2}$ greater than 0.8 is classified as "very good," 0.70 to 0.80 as "good," 0.60 to 0.70 as "fair," and less than 0.60 as "unsatisfactory" (table 4). The RSR is the ratio of the RMSE to SD, which provides an indication of the model fit. Moriasi and others (2007) provide performance rating guidelines of "very good” to "unsatisfactory" for the monthly NSE and RSR statistics (table 4).

Table 4. Evaluation criteria for Hydrological Simulation Program—FORTRAN (HSPF) model simulation results based on Donigian (2002) and Moriasi and others (2007).

[RMSE-SD, root mean squared error to standard deviation of observations ratio, also referred to as "RSR"; <, less than; >, greater than]

\begin{tabular}{lccccc}
\hline $\begin{array}{c}\text { Performance } \\
\text { rating }\end{array}$ & $\begin{array}{c}\text { Daily mean } \\
\text { streamflow } \\
\text { percent difference }\end{array}$ & $\begin{array}{c}\text { Daily mean } \\
\text { suspended-sediment } \\
\text { percent difference }\end{array}$ & $\begin{array}{c}\text { Coefficient of } \\
\text { determination } \\
\text { (R² }^{\mathbf{1}}\end{array}$ & $\begin{array}{c}\text { Nash-Sutcliffe } \\
\text { efficiency }^{2} \\
\text { (NSE) }\end{array}$ & $\begin{array}{c}\text { RMSE-SD } \\
\text { (RSR) }\end{array}$ \\
\hline Very good & $<10$ & $<15$ & $>0.80$ & $>0.75$ \\
Good & $10-15$ & $15-30$ & $0.70-0.80$ & $0.65-0.75$ \\
Fair & $15-25$ & $30-55$ & $0.60-0.70$ & $0.50-0.65$ & $0.50-0.60$ \\
Unsatisfactory & $>25$ & $>55$ & $<0.60$ & $<0.65$ & $0.60-0.70$ \\
\hline
\end{tabular}

\footnotetext{
${ }^{1}$ Applicable to daily mean streamflow values.

${ }^{2}$ Applicable to monthly mean streamflow or monthly mean sediment values.
} 
Four USGS streamflow-gaging stations were selected as primary calibration sites in the study area (SAR Falls City, Cibolo Falls City, Ecleto Runge, and SAR Goliad), with each gage representing a separate watershed HSPF model (upper SAR, Cibolo, Ecleto, and lower SAR models, respectively). During 2006-12, the percent differences between measured and simulated daily mean streamflow at each primary calibration site were all within 10 percent (table 5) and were rated as a "very good" fit. For comparison of daily mean streamflows, $\mathrm{R}^{2}$ ranged from 0.77 to 0.94 ("good” to "very good" fits), except for the Ecleto Runge gage which was 0.42 ("unsatisfactory" fit). For monthly mean streamflows at each primary calibration site, the NSE was greater than 0.79 ("good" to "very good" fits), and the RSR ranged from 0.22 to 0.50 ("very good" fits). In general, peak discharges, which are primarily driven by rainfall intensity and timing, were often challenging for the model to replicate. In addition to evaluating simulated daily streamflow time-series data, it is important to evaluate exceedance-probability curves and scatter plots (figs. 9-12) to ensure that a few high-flow events do not skew the average streamflow values (Moriasi and others, 2007). Evaluation of the model-fit statistics and graphical comparisons at the most downstream streamflowcalibration gage (SAR Goliad gage), which incorporates simulated streamflow from all four watershed HSPF models, indicated the streamflow calibration was "very good."

Calibration model-fit statistics for the Ecleto Runge gage indicated a lower quality fit than at the other gages (table 5). This lower quality fit was likely because there were frequent periods when the stream did not flow. The NSE was notably sensitive to periods of very low streamflow (for example, flows less than $1 \mathrm{ft}^{3} / \mathrm{s}$ ), and hence, only the $\mathrm{R}^{2}$ was reported for daily mean streamflow $\left(\mathrm{R}^{2}=0.42\right)$; however, on a monthly basis, the model fit improved. Another possible reason for the lesser quality model fit was lack of rainfall data. The Ecleto Creek watershed did not have a rain gage within its boundaries, so rainfall data for model input from stations in adjacent watersheds were used. In contrast, the other three watersheds included at least one NWS daily rainfall station and at least one USGS streamflow-gaging station that also recorded hourly rainfall.

After completing the calibration process, post-calibration tests of the model fit were performed at each of the calibration gages during 2000-2005, except for the Ecleto Runge gage, which was not in operation during 2000-2002. During the testing period, model parameters were not further adjusted to attempt to improve the model fit. Rather, the testing period was an independent evaluation of model performance. During the testing period, simulated daily mean streamflow at the SAR Falls City and SAR Goliad gages was within 10 percent of the measured daily mean streamflow ("very good" fit) and was 20.5 percent less at the Cibolo Falls City gage ("fair" fit) (table 5). Model-fit statistics ( $\mathrm{R}^{2}$ greater than 0.77 ) for daily mean streamflow the SAR Falls City, Cibolo Falls City, and SAR Goliad gages during the testing period indicated "good" to "very good" fits. Monthly mean streamflow model-fit statistics were "very good" fits (NSEs were greater than 0.93, and RSRs were less than 0.50 at each gage). As shown in table 5, the simulations during the testing period had similar model-fit statistics as during the calibration period, with the exception of the Cibolo Falls City gage. One possible reason for weaker testing results (compared with calibration results) was that the quality of available rainfall data for 2000-2005 was likely poorer than the 2006-12 data. During the calibration period, the daily rainfall was disaggregated from daily to hourly rainfall using nearby USGS hourly rainfall gages located at USGS streamflow-gaging stations (table 1); however, during the testing period, hourly data were not available from the USGS rain gages, and thus available hourly data from the NWS Stinson station were used to disaggregate the daily rainfall or the WDMUtil program triangular distribution method was applied (Hummel and others, 2001). The intensity and timing of rainfall are especially important during large stormflow events, such as those that occurred during 2002 and 2004.

In addition to the primary calibration sites, testing of model streamflow simulation also was done at USGS streamflow-gaging station 08183200 San Antonio River near Floresville, Tex. (hereinafter referred to as the "SAR Floresville gage”); Cibolo St. Hedwig gage; USGS streamflow-gaging station 08185100 Martinez Creek near Saint Hedwig, Tex. (hereinafter referred to as the "Martinez St. Hedwig gage”); and the Cibolo Sutherland Springs and SAR McFaddin gages. All of these gages were installed during 2005 and did not have a sufficient period of record for separate calibration and testing periods. Because streamflow at the Martinez St. Hedwig gage was likely in backwater conditions during periods of high flow in Cibolo Creek (Richard Slattery, USGS, oral commun., 2014), this gage was not used for testing purposes. The streamflow percent difference during the 2006-12 testing period was less than 10 percent for the SAR Floresville, Cibolo Sutherland Springs, and SAR McFaddin gages ("very good" fits). The simulated percent difference for the Cibolo St. Hedwig gage was 25 percent. Considering streamflow percent differences and model-fit statistics $\left(\mathrm{R}^{2}\right.$, NSE, and RSR), the test-gage simulations indicated "fair" to "very good" model fits (table 5). SAR McFaddin is the most downstream gage in the watershed and monitors streamflow from about 98.5 percent of the study area watershed. Testing results at this gage provide an important evaluation of the model's ability to accurately assess streamflow and suspendedsediment discharges near the outlet of the study watershed. Streamflow simulation testing results at the SAR McFaddin gage for 2006-12 indicate a 7.2 percent difference in daily mean streamflow ("very good" fit), daily mean streamflow $\mathrm{R}^{2}$ of 0.64 ("fair" fit), and monthly mean streamflow R², NSE, and RSR indicating a "very good" fit.

During the 2000-12 simulation period, the model-fit statistics at each of the calibration gages (SAR Falls City, Cibolo Falls City, and SAR Goliad) indicate "good" to "very good" fits. Overall, model-fit statistics and graphic evaluations from the calibration and testing periods, provide multiple lines of evidence indicating the USGS-2014 model simulations of hydrologic conditions were mostly "good" to "very good." 
Table 5. Streamflow and suspended-sediment load calibration and testing results, Hydrologic Simulation Program—FORTRAN (HSPF) model of the study area in the San Antonio River Basin downstream from San Antonio, Texas, 2000-12.

[USGS, U.S. Geological Survey; SAR, San Antonio River; ft³/s, cubic feet per second; SSL, suspended-sediment load; tons/d, tons per day; RMSE, root mean squared error; --, not determined]

\section{Streamflow and suspended-sediment loads at SAR Falls City (USGS station 08183500 San Antonio River near Falls City, Texas)}

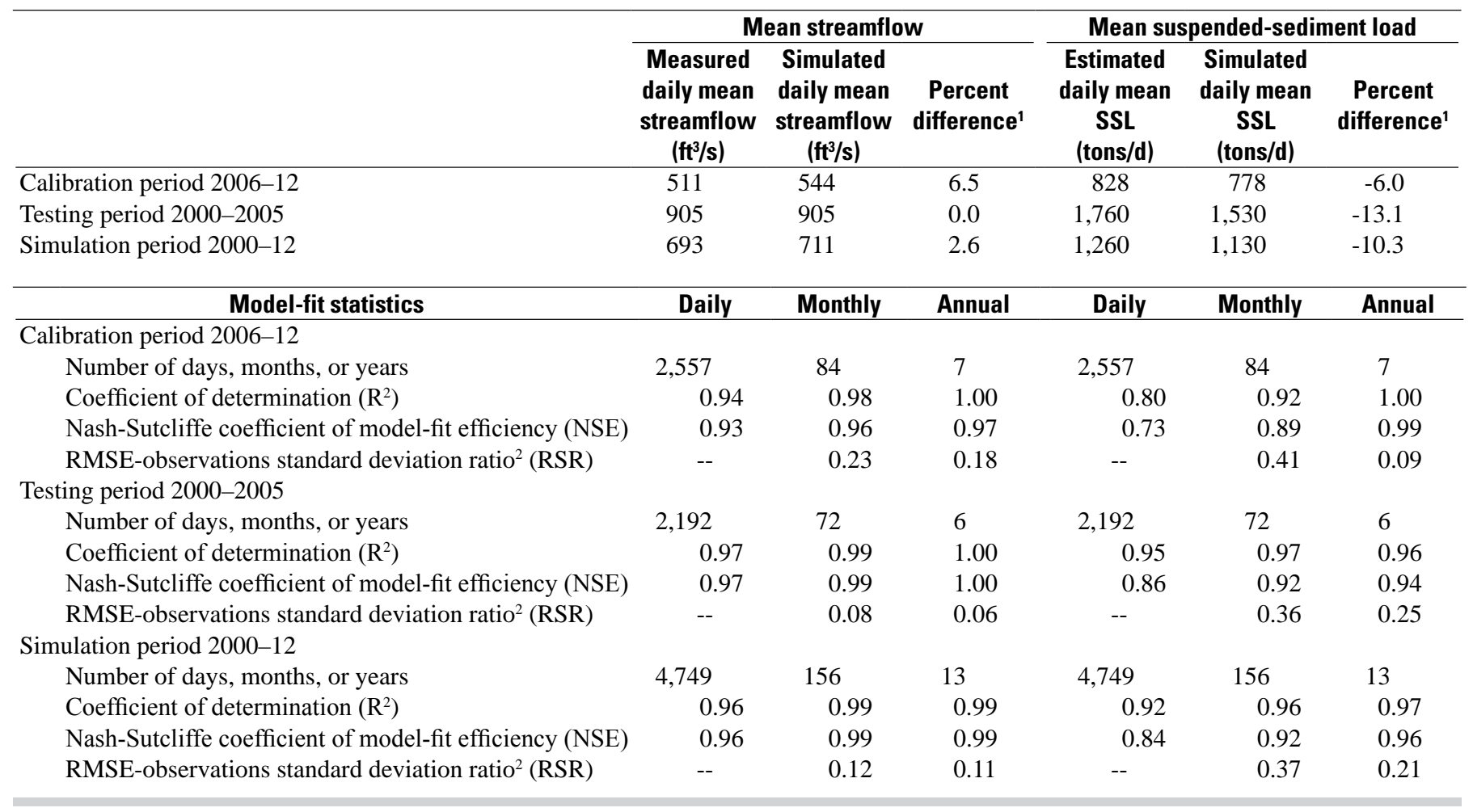

Streamflow and suspended-sediment loads at Cibolo Falls City (USGS station 08186000 Cibolo Creek near Falls City, Texas)

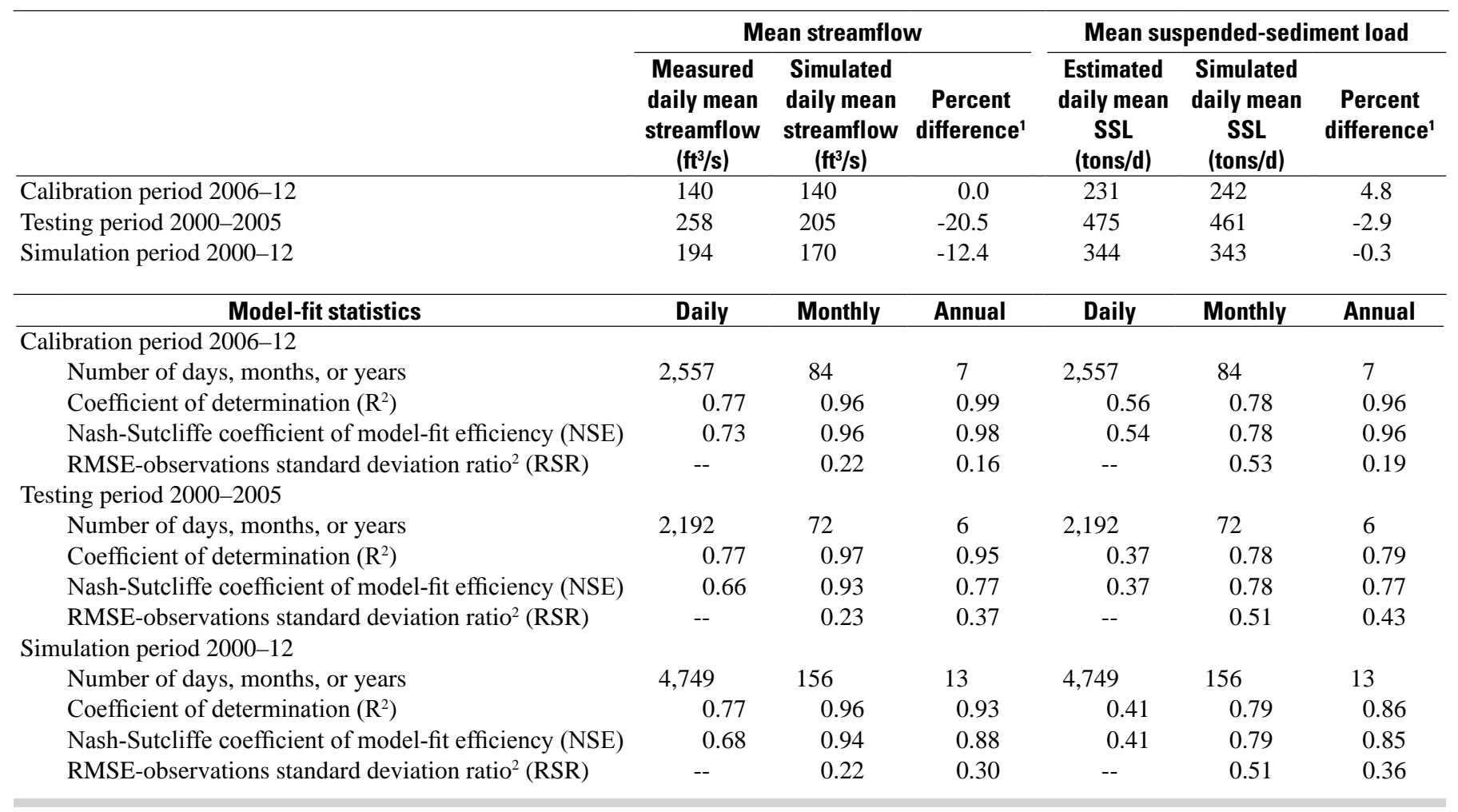


Table 5. Streamflow and suspended-sediment load calibration and testing results, Hydrologic Simulation Program-FORTRAN (HSPF) model of the study area in the San Antonio River Basin downstream from San Antonio, Texas, 2000-12.—Continued

[USGS, U.S. Geological Survey; SAR, San Antonio River; ft³/s, cubic feet per second; SSL, suspended-sediment load; tons/d, tons per day; RMSE, root mean squared error; --, not determined]

Comparison of daily mean streamflow at Ecleto Runge (USGS station 08186500 Ecleto Creek near Runge, Texas)

\begin{tabular}{|c|c|c|c|c|c|c|}
\hline & \multicolumn{3}{|c|}{ Mean streamflow } & \multicolumn{3}{|c|}{ Mean suspended-sediment load } \\
\hline & $\begin{array}{l}\text { Measured } \\
\text { daily mean } \\
\text { streamflow } \\
\left(\mathrm{ft}^{3} / \mathbf{s}\right)\end{array}$ & $\begin{array}{c}\text { Simulated } \\
\text { daily mean } \\
\text { streamflow } \\
\left(\mathbf{f t}^{3} / \mathbf{s}\right)\end{array}$ & $\begin{array}{c}\text { Percent } \\
\text { difference }^{1}\end{array}$ & $\begin{array}{c}\text { Estimated } \\
\text { daily mean } \\
\text { SSL } \\
\text { (tons/d) }\end{array}$ & $\begin{array}{c}\text { Simulated } \\
\text { daily mean } \\
\text { SSL } \\
\text { (tons/d) }\end{array}$ & $\begin{array}{c}\text { Percent } \\
\text { difference }\end{array}$ \\
\hline Calibration period 2006-12 & 27 & 28 & 3.7 & 42 & 41 & -2.4 \\
\hline \multicolumn{7}{|l|}{ Calibration period 2006-12 } \\
\hline Number of days, months, or years & 2,557 & 84 & 7 & 2,557 & 84 & 7 \\
\hline Coefficient of determination $\left(\mathrm{R}^{2}\right)$ & 0.42 & 0.79 & 0.97 & 0.11 & 0.59 & 0.99 \\
\hline Nash-Sutcliffe coefficient of model-fit efficiency (NSE) & $--^{3}$ & 0.79 & 0.94 & $--^{3}$ & 0.58 & 0.99 \\
\hline RMSE-observations standard deviation ratio² (RSR) & -- & 0.50 & 0.18 & -- & 0.97 & 0.09 \\
\hline
\end{tabular}

Streamflow and suspended-sediment loads at SAR Goliad (USGS station 08188500 San Antonio River at Goliad, Texas)

\begin{tabular}{|c|c|c|c|c|c|c|}
\hline & \multicolumn{3}{|c|}{ Mean streamflow } & \multicolumn{3}{|c|}{ Mean suspended-sediment load } \\
\hline & $\begin{array}{c}\text { Measured } \\
\text { daily mean } \\
\text { streamflow } \\
\left(\mathrm{ft}^{3} / \mathrm{s}\right)\end{array}$ & $\begin{array}{c}\text { Simulated } \\
\text { daily mean } \\
\text { streamflow } \\
\left(\mathrm{ft}^{3} / \mathbf{s}\right)\end{array}$ & $\begin{array}{c}\text { Percent } \\
\text { difference }^{1}\end{array}$ & $\begin{array}{l}\text { Estimated } \\
\text { daily mean } \\
\text { SSL } \\
\text { (tons/d) }\end{array}$ & $\begin{array}{c}\text { Simulated } \\
\text { daily mean } \\
\text { SSL } \\
\text { (tons/d) }\end{array}$ & $\begin{array}{c}\text { Percent } \\
\text { difference }^{1}\end{array}$ \\
\hline Calibration period 2006-12 & 757 & 820 & 8.3 & 1,200 & 1,180 & -1.7 \\
\hline Testing period 2000-2005 & 1,400 & 1,300 & -7.1 & 2,640 & 2,190 & -17.0 \\
\hline Model-fit statistics & Daily & Monthly & Annual & Daily & Monthly & Annual \\
\hline \multicolumn{7}{|l|}{ Calibration period 2006-12 } \\
\hline Number of days, months, or years & 2,557 & 84 & 7 & 2,557 & 84 & 7 \\
\hline Coefficient of determination $\left(\mathrm{R}^{2}\right)$ & 0.82 & 0.98 & 1.00 & 0.54 & 0.92 & 1.00 \\
\hline \multicolumn{7}{|l|}{ Testing period 2000-2005 } \\
\hline Number of days, months, or years & 2,192 & 72 & 6 & 2,192 & 72 & 6 \\
\hline Coefficient of determination $\left(\mathrm{R}^{2}\right)$ & 0.82 & 0.99 & 0.99 & 0.71 & 0.95 & 0.98 \\
\hline Nash-Sutcliffe coefficient of model-fit efficiency (NSE) & 0.82 & 0.98 & 0.97 & 0.66 & 0.91 & 0.94 \\
\hline RMSE-observations standard deviation ratio ${ }^{2}$ (RSR) & -- & 0.12 & 0.15 & -- & 0.39 & 0.25 \\
\hline \multicolumn{7}{|l|}{ Simulation period 2000-12 } \\
\hline Number of days, months, or years & 4,749 & 156 & 13 & 4,749 & 156 & 13 \\
\hline Coefficient of determination $\left(\mathrm{R}^{2}\right)$ & 0.81 & 0.97 & 0.97 & 0.67 & 0.94 & 0.97 \\
\hline Nash-Sutcliffe coefficient of model-fit efficiency (NSE) & 0.81 & 0.97 & 0.97 & 0.62 & 0.89 & 0.96 \\
\hline
\end{tabular}


Table 5. Streamflow and suspended-sediment load calibration and testing results, Hydrologic Simulation Program—FORTRAN (HSPF) model of the study area in the San Antonio River Basin downstream from San Antonio, Texas, 2000-12.-Continued

[USGS, U.S. Geological Survey; SAR, San Antonio River; $\mathrm{ft} \mathrm{3}^{3} \mathrm{~s}$, cubic feet per second; SSL, suspended-sediment load; tons/d, tons per day; RMSE, root mean squared error; --, not determined]

Comparison of daily mean streamflow at SAR Floresville (USGS station 08183200 San Antonio River near Floresville, Texas)

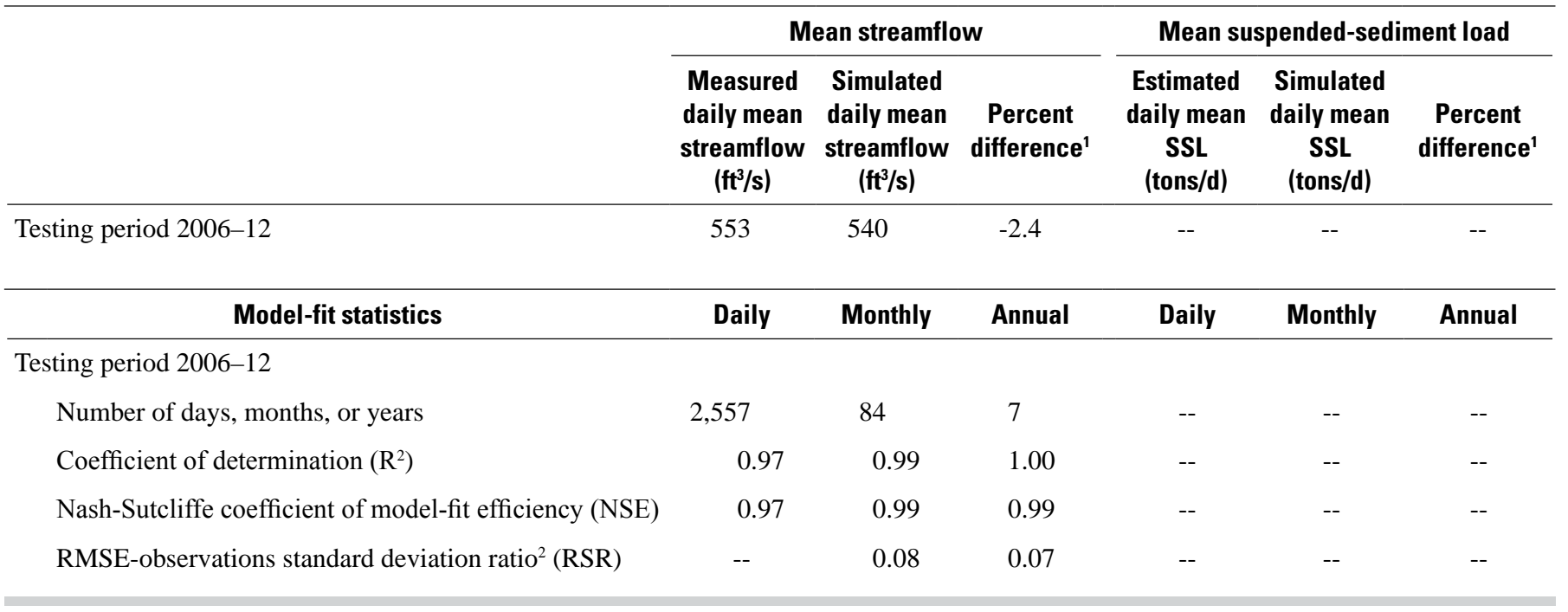

Comparison of daily mean streamflow at Cibolo St. Hedwig (USGS station 08185065 Cibolo Creek near St. Hedwig, Texas)

\begin{tabular}{|c|c|c|c|c|c|c|}
\hline & \multicolumn{3}{|c|}{ Mean streamflow } & \multicolumn{3}{|c|}{ Mean suspended-sediment load } \\
\hline Testing period 2006-12 & 28 & 35 & 25.0 & -- & -- & -- \\
\hline \multicolumn{7}{|l|}{ Testing period 2006-12 } \\
\hline Number of days, months, or years & 2,557 & 84 & 7 & -- & -- & -- \\
\hline Coefficient of determination $\left(\mathrm{R}^{2}\right)$ & 0.82 & 0.91 & 0.97 & -- & -- & -- \\
\hline Nash-Sutcliffe coefficient of model-fit efficiency (NSE) & 0.78 & 0.75 & 0.83 & -- & -- & -- \\
\hline
\end{tabular}


Table 5. Streamflow and suspended-sediment load calibration and testing results, Hydrologic Simulation Program—FORTRAN (HSPF) model of the study area in the San Antonio River Basin downstream from San Antonio, Texas, 2000-12. Continued

[USGS, U.S. Geological Survey; SAR, San Antonio River; ft³/s, cubic feet per second; SSL, suspended-sediment load; tons/d, tons per day; RMSE, root mean squared error; --, not determined]

Comparison of daily mean streamflow at Cibolo Sutherland Springs (USGS station 08185500 Cibolo Creek at Sutherland Springs, Texas)

\begin{tabular}{|c|c|c|c|c|c|c|}
\hline & \multicolumn{3}{|c|}{ Mean streamflow } & \multicolumn{3}{|c|}{ Mean suspended-sediment load } \\
\hline & $\begin{array}{c}\text { Measured } \\
\text { daily mean } \\
\text { streamflow } \\
\left(\mathrm{ft}^{3} / \mathrm{s}\right)\end{array}$ & $\begin{array}{c}\text { Simulated } \\
\text { daily mean } \\
\text { streamflow } \\
\left(\mathrm{ft}^{3} / \mathrm{s}\right)\end{array}$ & $\begin{array}{c}\text { Percent } \\
\text { difference }^{1}\end{array}$ & $\begin{array}{c}\text { Estimated } \\
\text { daily mean } \\
\text { SSL } \\
\text { (tons/d) }\end{array}$ & $\begin{array}{c}\text { Simulated } \\
\text { daily mean } \\
\text { SSL } \\
\text { (tons/d) }\end{array}$ & $\begin{array}{c}\text { Percent } \\
\text { difference }^{1}\end{array}$ \\
\hline Testing period 2006-12 & 108 & 106 & -1.9 & -- & -- & -- \\
\hline \multicolumn{7}{|l|}{ Testing period 2006-12 } \\
\hline Number of days, months, or years & 2,557 & 84 & 7 & -- & -- & -- \\
\hline Coefficient of determination $\left(\mathrm{R}^{2}\right)$ & 0.78 & 0.95 & 0.99 & -- & -- & -- \\
\hline Nash-Sutcliffe coefficient of model-fit efficiency (NSE) & 0.67 & 0.94 & 0.99 & -- & -- & -- \\
\hline RMSE-observations standard deviation ratio² (RSR) & -- & 0.23 & 0.09 & -- & -- & -- \\
\hline
\end{tabular}

Comparison of daily mean streamflow at SAR McFaddin (USGS station 08188570 San Antonio River near McFaddin, Texas)

\begin{tabular}{|c|c|c|c|c|c|c|}
\hline & \multicolumn{3}{|c|}{ Mean streamflow } & \multicolumn{3}{|c|}{ Mean suspended-sediment load } \\
\hline & $\begin{array}{c}\text { Measured } \\
\text { daily mean } \\
\text { streamflow } \\
\left(\mathrm{ft}^{3} / \mathbf{s}\right)\end{array}$ & $\begin{array}{c}\text { Simulated } \\
\text { daily mean } \\
\text { streamflow } \\
\left(\mathrm{ft}^{3} / \mathbf{s}\right)\end{array}$ & $\begin{array}{c}\text { Percent } \\
\text { difference }^{1}\end{array}$ & $\begin{array}{c}\text { Estimated } \\
\text { daily mean } \\
\text { SSL } \\
\text { (tons/d) }\end{array}$ & $\begin{array}{c}\text { Simulated } \\
\text { daily } \\
\text { mean } \\
\text { SSL } \\
\text { (tons/d) }\end{array}$ & $\begin{array}{c}\text { Percent } \\
\text { difference }^{1}\end{array}$ \\
\hline Testing period 2006-12 & 801 & 859 & 7.2 & -- & -- & -- \\
\hline \multicolumn{7}{|l|}{ Testing period 2006-12 } \\
\hline Number of days, months, or years & 2,557 & 84 & 7 & -- & -- & -- \\
\hline Coefficient of determination $\left(\mathrm{R}^{2}\right)$ & 0.64 & 0.92 & 1.00 & -- & -- & -- \\
\hline Nash-Sutcliffe coefficient of model-fit efficiency (NSE) & 0.63 & 0.89 & 0.96 & -- & -- & -- \\
\hline
\end{tabular}

${ }^{1}$ Percent difference $=[($ simulated - measured $) /$ measured $] \times 100$.

${ }^{2}$ RMSE-observations standard deviation ratio not calculated for daily mean streamflow or daily mean suspended-sediment load.

${ }^{3}$ Nash-Sutcliffe coefficient of model-fit efficiency not calculated because of frequent periods of no streamflow. 

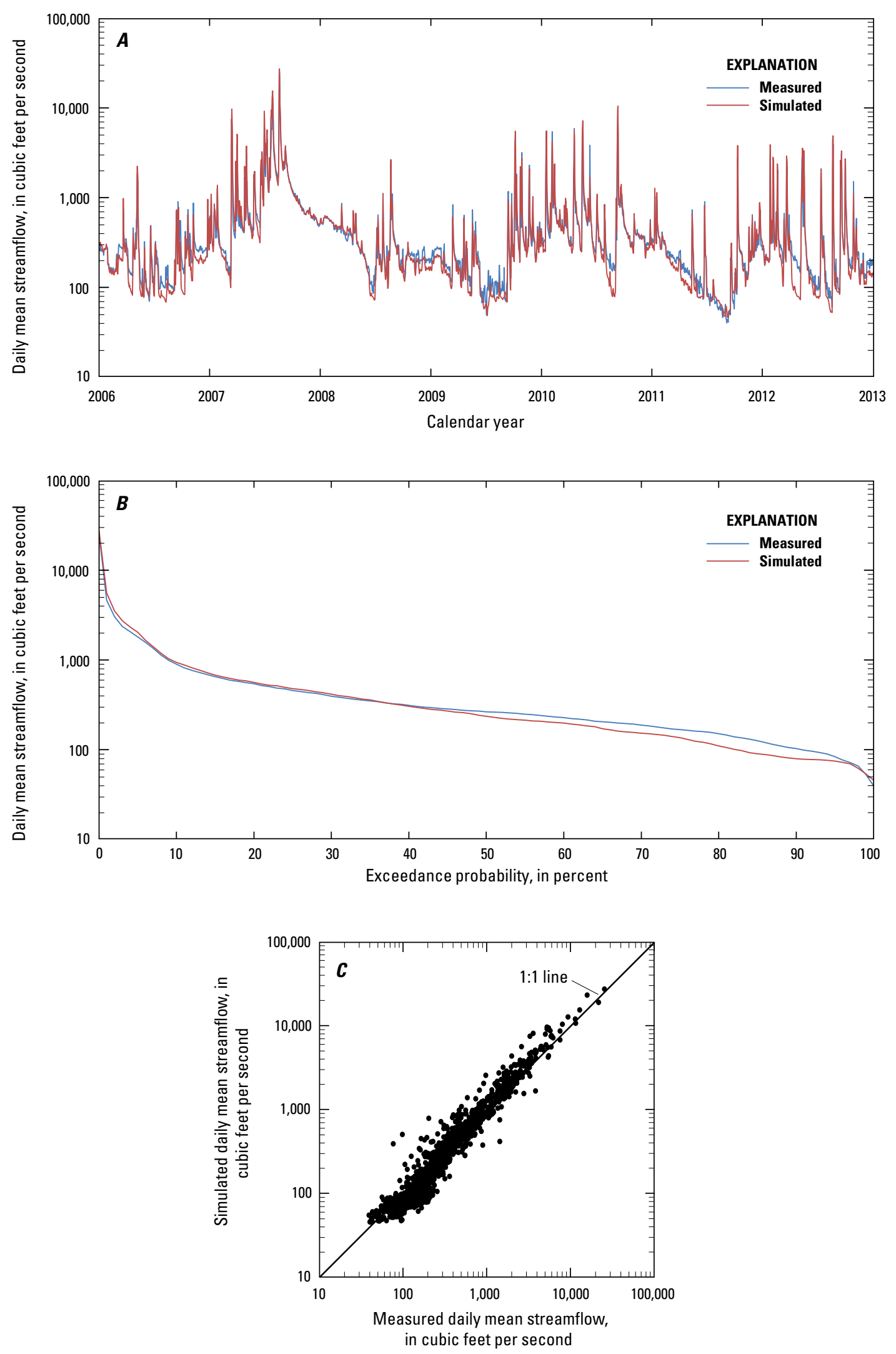

Figure 9. Comparison of $A-C$, Measured and simulated daily mean streamflow at U.S. Geological Survey streamflow-gaging station 08183500, San Antonio River near Falls City, Texas (SAR Falls City gage), 2006-12; D-F, Estimated and simulated daily mean suspendedsediment loads at the SAR Falls City gage, 2006-12. 

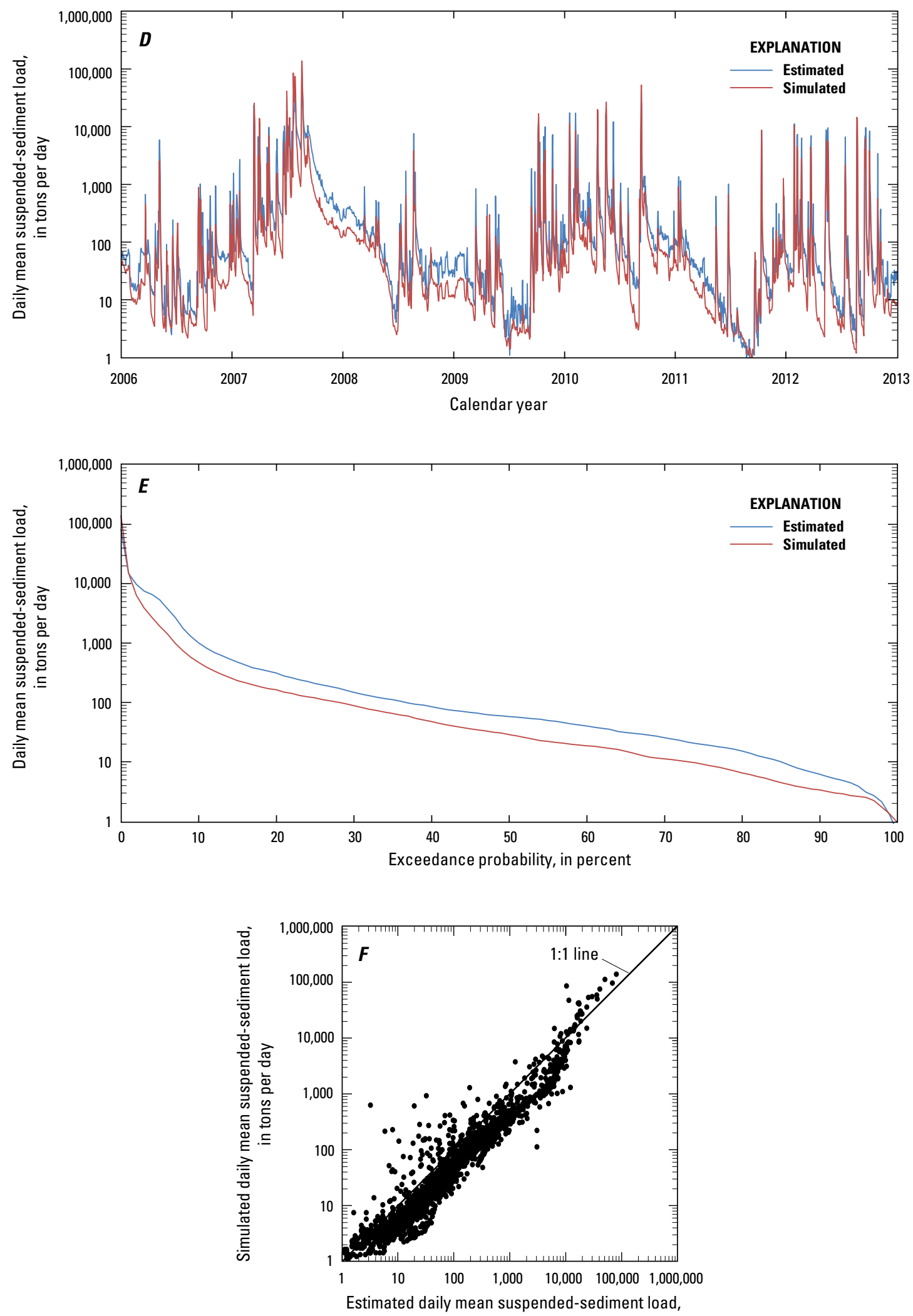

in tons per day

Figure 9. Graphs showing comparison of $A-C$, Measured and simulated daily mean streamflow at U.S. Geological Survey streamflowgaging station 08183500, San Antonio River near Falls City, Texas (SAR Falls City gage), 2006-12; $D-F$, Estimated and simulated daily mean suspended-sediment loads at the SAR Falls City gage, 2006-12.-Continued 

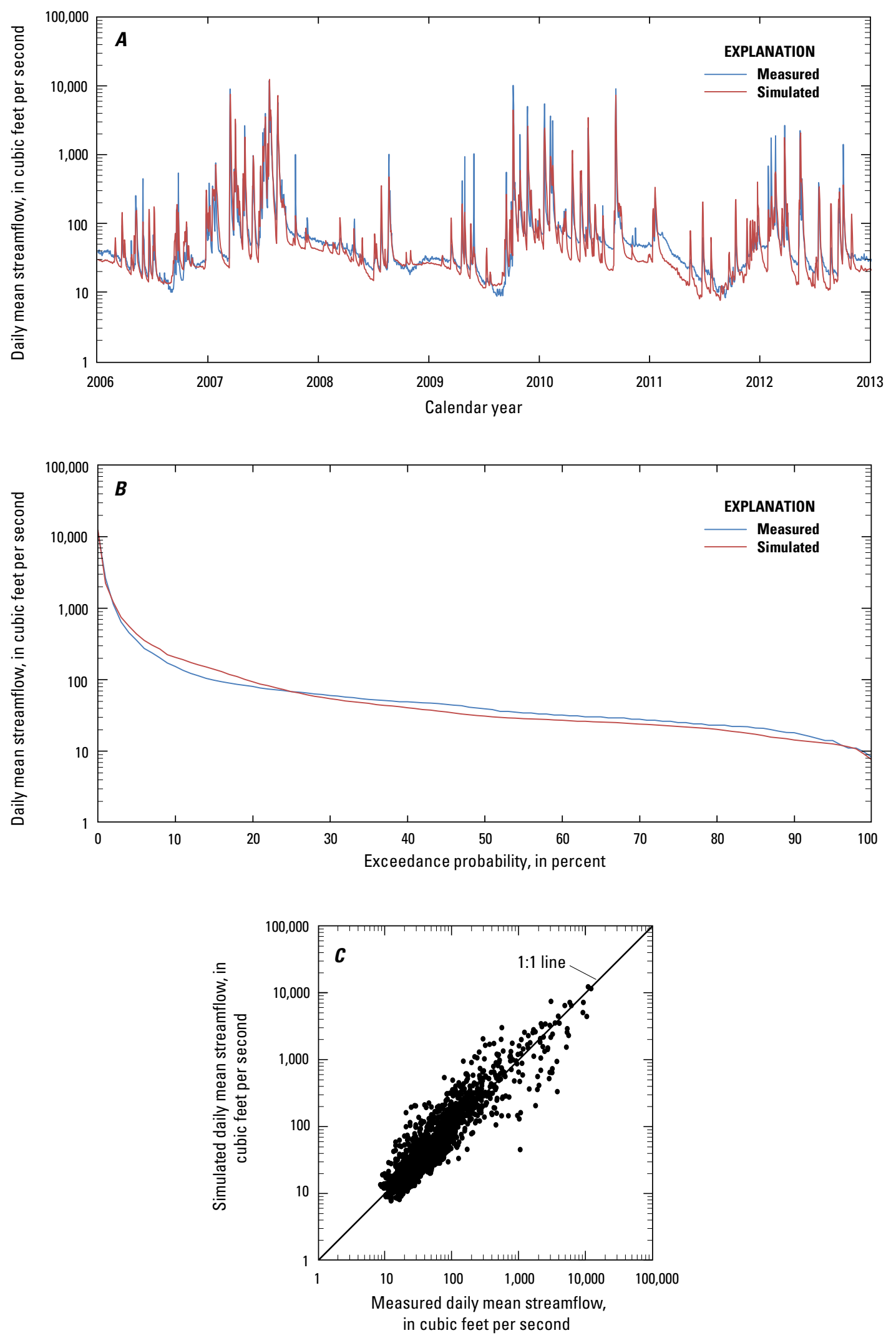

Figure 10. Comparison of $A-C$, Measured and simulated daily mean streamflow at U.S. Geological Survey streamflow-gaging station 08186000, Cibolo Creek near Falls City, Texas (Cibolo Falls City gage), 2006-12; D-F, Estimated and simulated daily mean suspendedsediment loads at the Cibolo Falls City gage, 2006-12. 

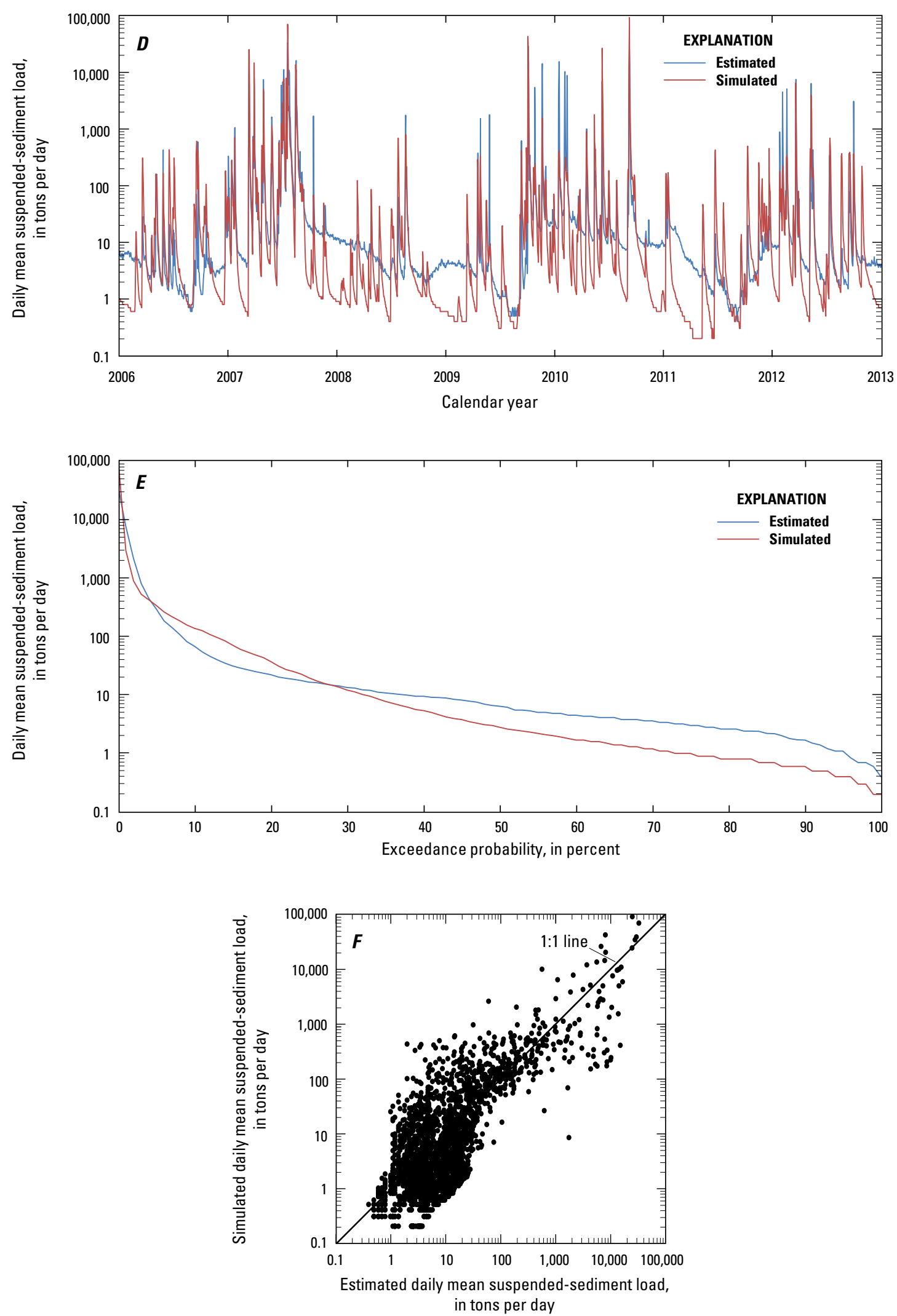

Figure 10. Graphs showing comparison of $A-C$, Measured and simulated daily mean streamflow at U.S. Geological Survey streamflowgaging station 08186000, Cibolo Creek near Falls City, Texas (Cibolo Falls City gage), 2006-12; $D-F$, Estimated and simulated daily mean suspended-sediment loads at the Cibolo Falls City gage, 2006-12.-Continued 

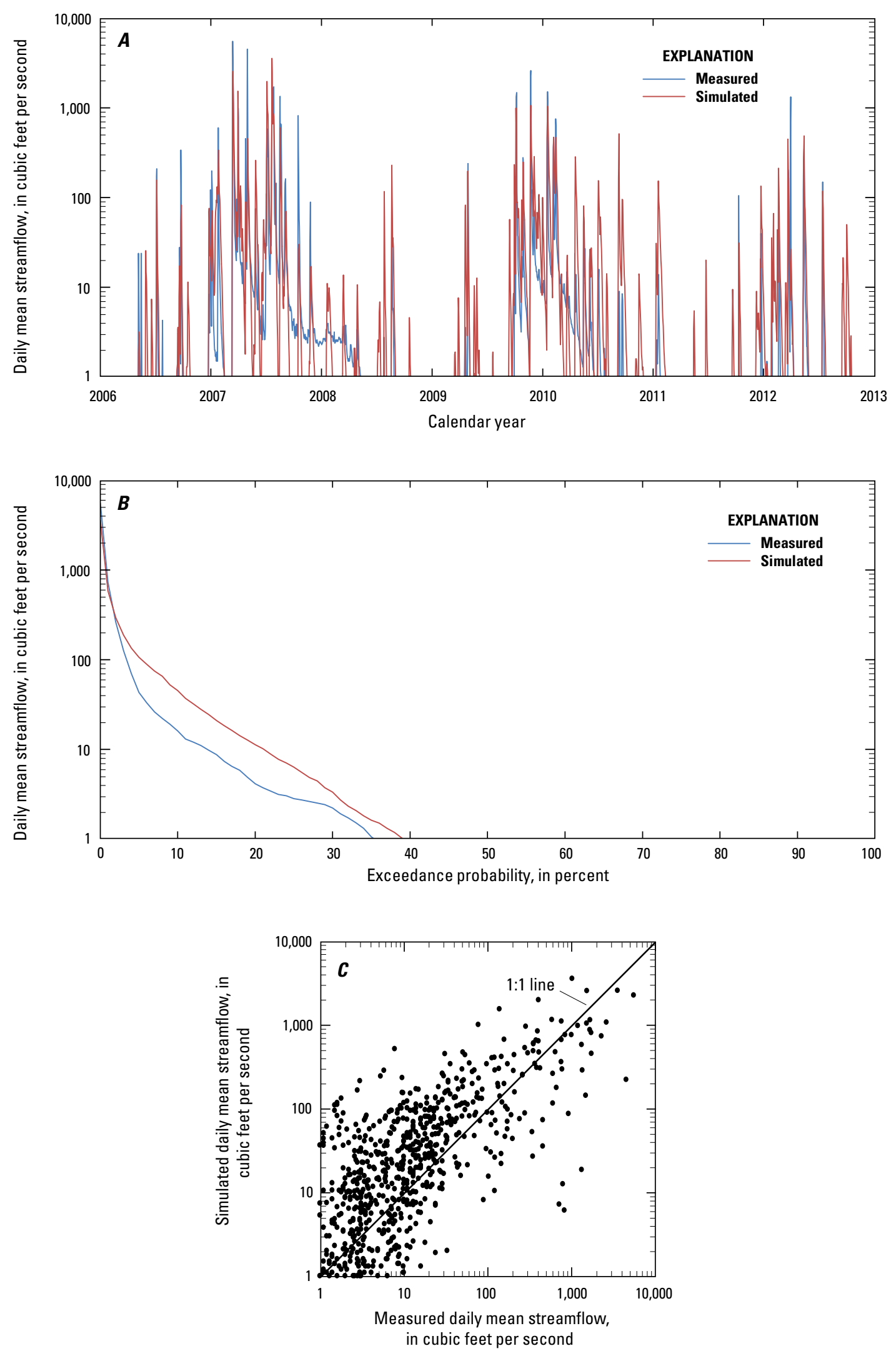

Figure 11. Comparison of $A-C$, Measured and simulated daily mean streamflow at U.S. Geological Survey streamflow-gaging station 08186500 Ecleto Creek near Runge, Texas (Ecleto Runge gage), 2006-12; $D-F$, Estimated and simulated daily mean suspended-sediment loads at the Ecleto Runge gage, 2006-12. 

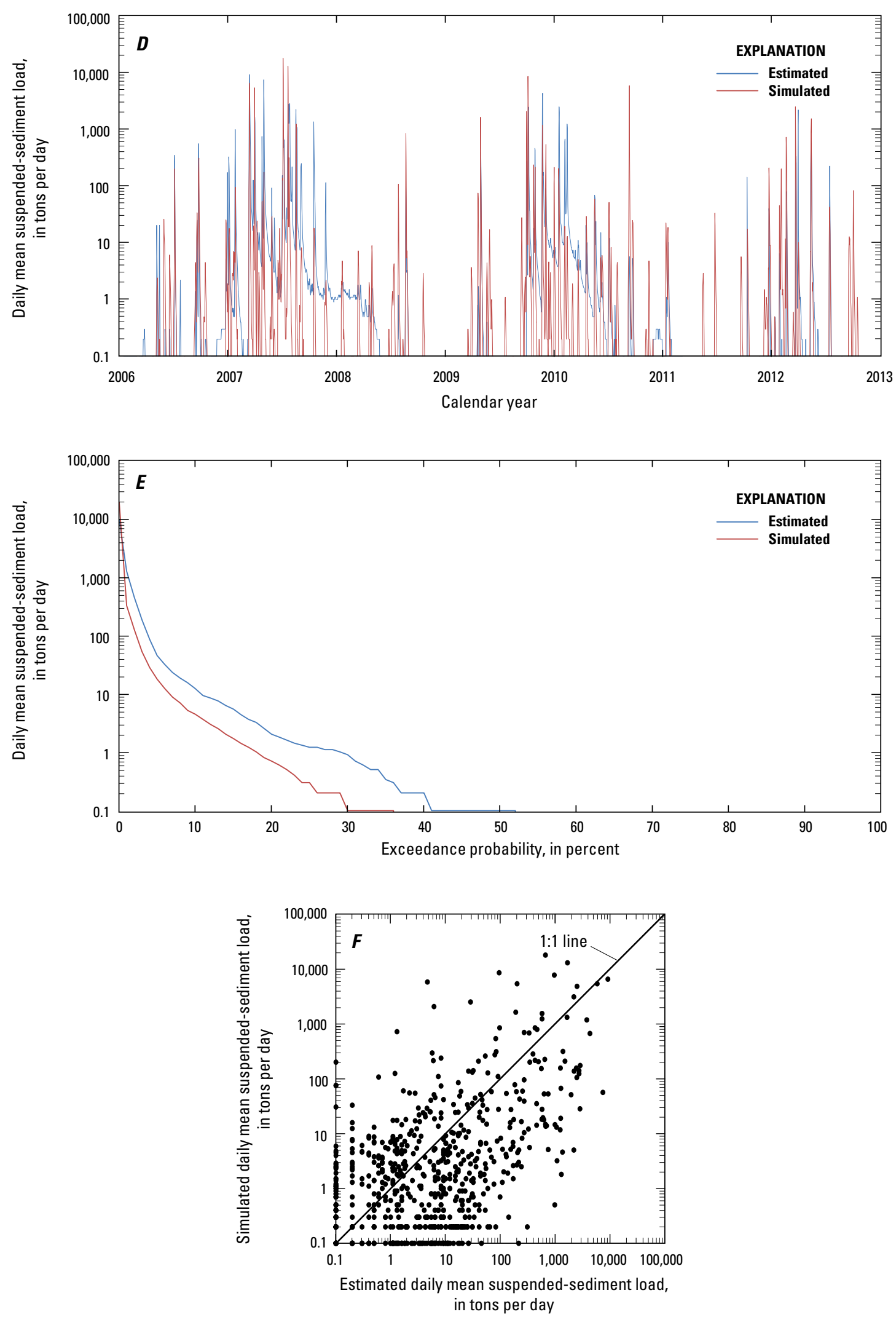

Figure 11. Graphs showing comparison of $A-C$, Measured and simulated daily mean streamflow at U.S. Geological Survey streamflowgaging station 08186500 Ecleto Creek near Runge, Texas (Ecleto Runge gage), 2006-12; $D-F$, Estimated and simulated daily mean suspended-sediment loads at the Ecleto Runge gage, 2006-12.-Continued 

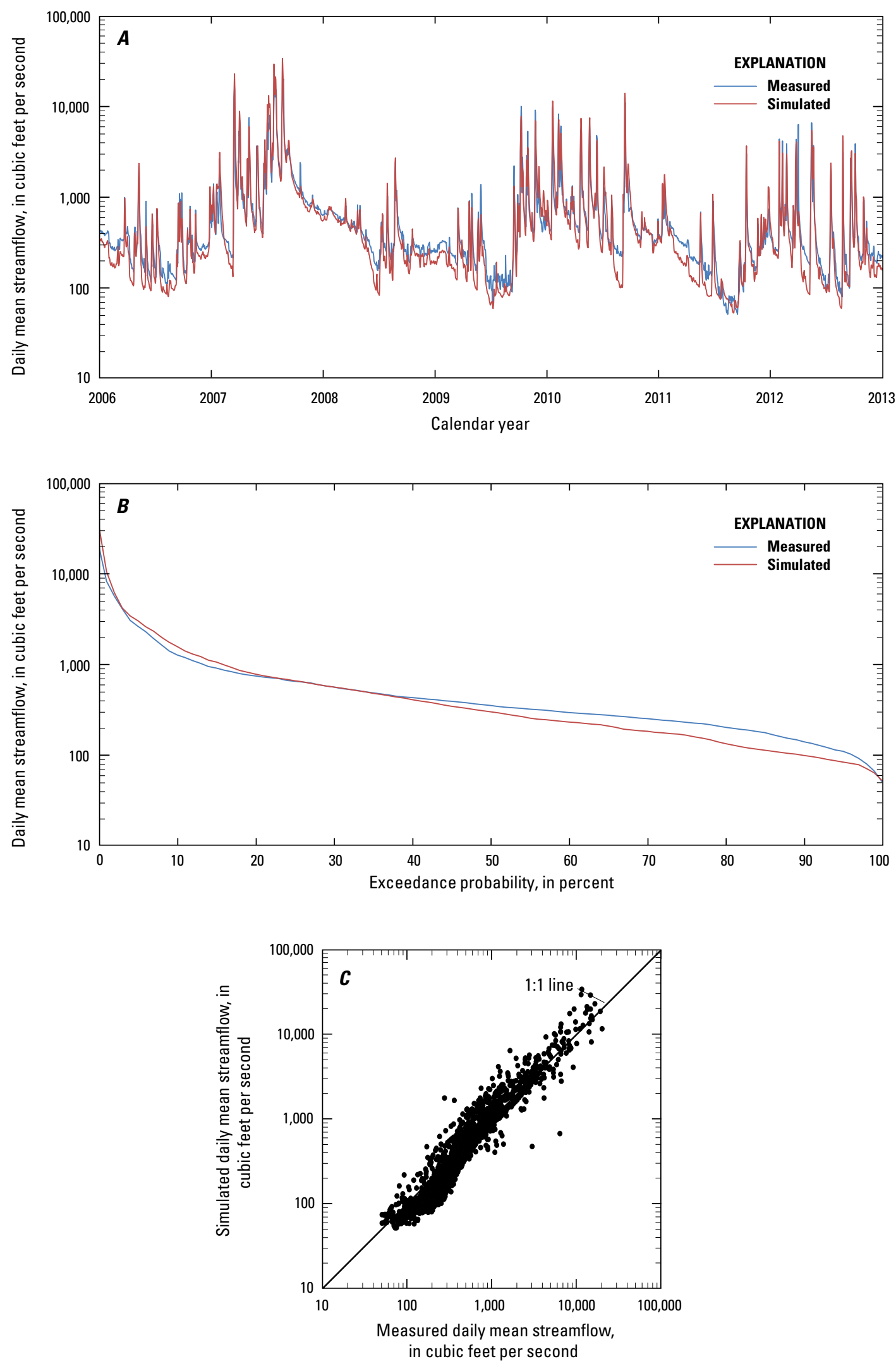

Figure 12. Comparison of $A-C$, Measured and simulated daily mean streamflow at U.S. Geological Survey streamflow-gaging station 08188500, San Antonio River at Goliad, Texas (SAR Goliad gage), 2006-12; D-F, Estimated and simulated daily mean suspended-sediment loads at the SAR Goliad gage, 2006-12. 

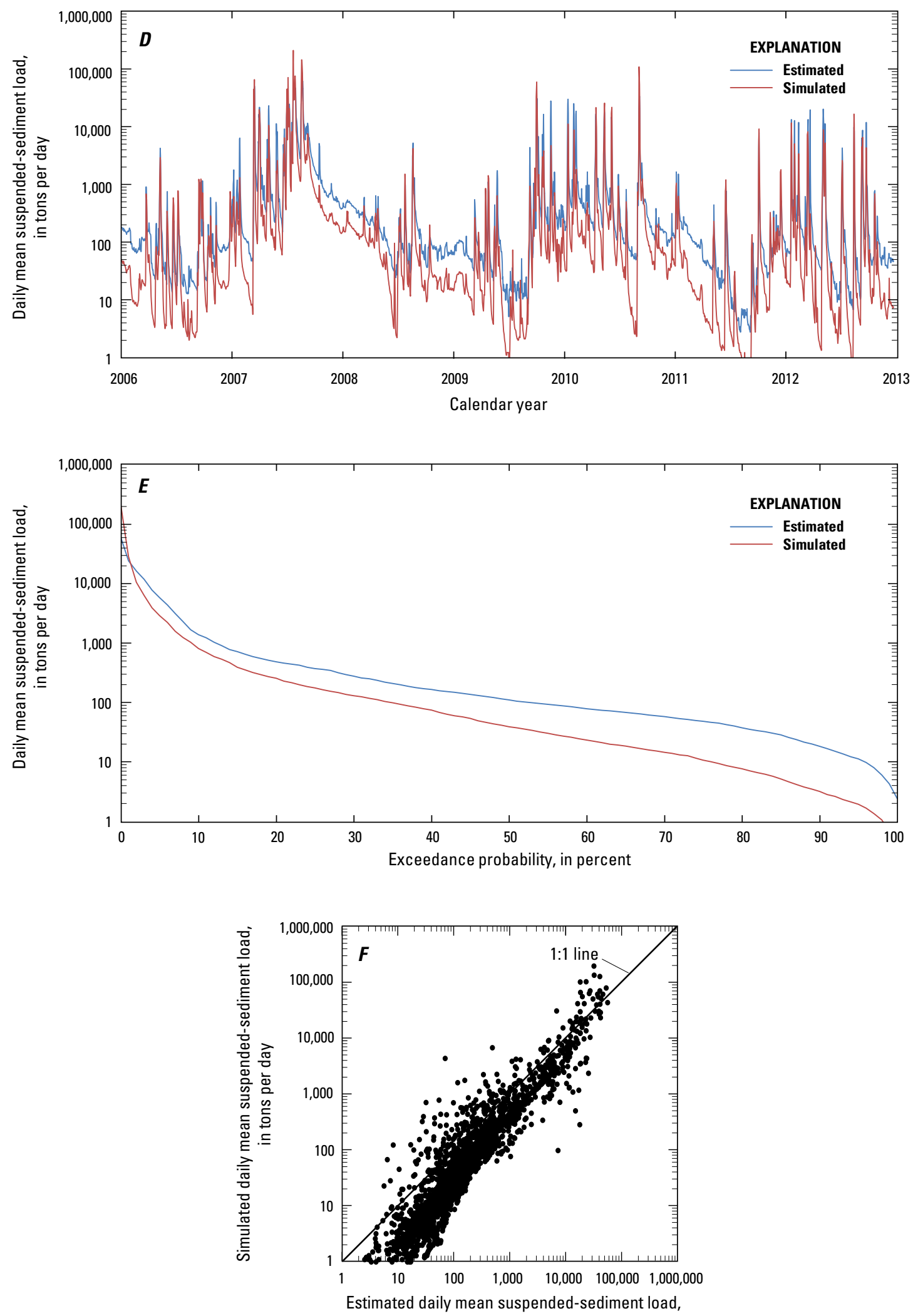

in tons per day

Figure 12. Graphs showing comparison of $A-C$, Measured and simulated daily mean streamflow at U.S. Geological Survey streamflowgaging station 08188500, San Antonio River at Goliad, Texas (SAR Goliad gage), 2006-12; $D-F$, Estimated and simulated daily mean suspended-sediment loads at the SAR Goliad gage, 2006-12.-Continued 
Simulated evapotranspiration (ET) rates were compared with available ET data collected in a nearby watershed with similar land use and surface geology (ET measurements in the study area were not available). During 2007-09, the USGS operated meteorological station 290810099212100 SW Medina County meteorological station near D’Hanis, Tex. (hereinafter referred to as the "SW Medina ET site") to measure actual evapotranspiration continuously by using the eddy covariance method (Slattery and others, 2011). The SW Medina ET site is about 70 miles west of the study area (fig. 1); Medina County is not shown. The station was located on rangeland/shrubland where the surface geology was the Carrizo Sand (Slattery and others, 2011), which also outcrops in the study area (zone 3, fig. 2). Measured ET (during 2007-09) at the SW Medina ET site was compared to model-simulated ET from similar land types in zone 3 of the study area (rangeland/shrubland on the Carrizo Sand outcrop) (table 6). Because annual rainfall amounts were substantially different between the study area watershed and the watershed

Table 6. Rainfall and measured evapotranspiration from rangeland/shrubland on the Carrizo Sand, in Medina County, Texas, compared with rainfall and model-simulated evapotranspiration from rangeland and shrubland on the Carrizo Sand in the study area, San Antonio River Basin downstream from San Antonio, Tex., 2007-09.

\begin{tabular}{|c|c|c|c|}
\hline \multirow[b]{2}{*}{$\begin{array}{l}\text { Calendar } \\
\text { year }\end{array}$} & \multicolumn{3}{|c|}{$\begin{array}{l}\text { Measured rainfall and evapotranspiration from } \\
\text { Medina County meteorological station }{ }^{1}\end{array}$} \\
\hline & $\begin{array}{l}\text { Medina } \\
\text { County } \\
\text { rainfall } \\
\text { (inches) }\end{array}$ & $\begin{array}{c}\text { Medina County } \\
\text { evapotranspiration } \\
\text { (inches) }\end{array}$ & $\begin{array}{c}\text { Evapotranspiration } \\
\text { as a percentage } \\
\text { of rainfall } \\
\text { (percent) }\end{array}$ \\
\hline \multirow[t]{2}{*}{ 2007-09 } & 26.9 & 21.8 & 81 \\
\hline & \multicolumn{3}{|c|}{$\begin{array}{l}\text { Rainfall and simulated evapotranspiration from } \\
\text { model study area (San Antonio River Basin) }\end{array}$} \\
\hline $\begin{array}{l}\text { Calendar } \\
\text { year }\end{array}$ & $\begin{array}{l}\text { Model } \\
\text { study area } \\
\text { rainfall } \\
\text { (inches) }\end{array}$ & $\begin{array}{c}\text { Simulated } \\
\text { rangeland/ } \\
\text { shrubland } \\
\text { evapotranspiration } \\
\text { (inches) }\end{array}$ & $\begin{array}{l}\text { Evapotranspiration } \\
\text { as a percentage } \\
\text { of rainfall } \\
\text { (percent) }\end{array}$ \\
\hline 2007-09 & 35.2 & 25.9 & 74 \\
\hline
\end{tabular}

${ }^{1}$ Rainfall and evapotranspiration data collected at U.S. Geological Survey station 290810099212100 SW Medina Meteorological Station near D’Hanis, Texas.

${ }^{2}$ Rainfall from DAYMET in water-budget zone 3 (fig. 2) (Thornton and others, 2012).

${ }^{3}$ Model-simulated evapotranspiration from rangeland/shrubland on Carrizo Sand in water-budget zone 3 (fig. 2). of the SW Medina ET site, it was not possible to directly compare the model-simulated ET to the measured ET. Instead, ET was evaluated as a percent of rainfall in each watershed. During 2000-2009, measured Medina County ET was about 81 percent of rainfall and USGS-2014 simulations showed ET to be about 74 percent of rainfall, thus indicating reasonable simulation of ET by the model (table 6).

\section{Suspended Sediment}

Selection of initial values and calibration of sedimentrelated process parameters of the USGS-2014 model (app. 1) were based on published guidelines (U.S. Environmental Protection Agency, 2006). Calibration of sediment-related parameters involved the following steps: (1) estimation of suspended-sediment loads at upstream model boundaries (at the SAR Elmendorf and Cibolo Selma gages); (2) estimation of the soil-erosion and sediment-washoff parameters used to generate sediment washoff from PERLNDs and IMPLNDs, respectively, to match relative sediment erosion rates from the various land types in the watershed; and (3) calibration of sediment-transport (RCHRES) parameters by comparing simulated suspended-sediment loads with estimated suspended-sediment loads at the same streamflow-gaging stations used for primary streamflow calibration (SAR Falls City, Cibolo Falls City, Ecleto Runge, and SAR Goliad gages).

The calibration process involves adjusting model process parameters that control sediment yields from the various land-cover categories simulated in the model. The U.S. Environmental Protection Agency (EPA) provides general guidance for expected soil erosion rates for selected landcover categories (U.S. Environmental Protection Agency, 2006) (table 7). Previously reported soil erosion rates of specific land-cover types in the south Texas area also are listed in table 7 (Baird and others, 1996; Ockerman and others, 1999; Ockerman and Petri, 2001; Ockerman, 2002; Ockerman and Fernandez, 2010; Ockerman and others, 2013). The ranges of reported soil erosion rates were used as guidance for model calibration of sediment production from different land-cover categories. Sediment-related HSPF model parameters were adjusted so that simulated soil erosion rates approximated the reported soil erosion rates by land-cover type (U.S. Environmental Protection Agency, 2006).

Similar to the hydrology calibration, suspended sediment was evaluated by using the calibration period (2006-12) at four gages (SAR Falls City, Cibolo Falls City, Ecleto Runge, and SAR Goliad). The model-simulated and estimated suspended-sediment load (in units of tons per day) during the calibration period are depicted in figures $9 \mathrm{D}, \mathrm{E}, \mathrm{F}-12 \mathrm{D}$, $\mathrm{E}, \mathrm{F}$ and table 5. General goodness-of-fit metrics (Donigian, 2002; Moriasi and others, 2007) include (1) percent difference, (2) NSE, and (3) RSR. The percent difference between the simulated and estimated daily mean suspended-sediment load at each of the gages was less than 15 percent ("very good" fit). The monthly mean values for NSE ranged from 0.78 
Table 7. Reported and simulated ranges of soil erosion rates for land-cover types in south Texas and the study area, San Antonio River Basin downstream from San Antonio, Texas, 2006-12.

[(tons/mi²)/yr, tons per square mile per year; tons/yr, tons per year; --, not available]

\begin{tabular}{|c|c|c|c|c|}
\hline $\begin{array}{l}\text { Land-cover } \\
\text { type }\end{array}$ & $\begin{array}{c}\text { Area } \\
\text { (square } \\
\text { miles) }\end{array}$ & $\begin{array}{l}\text { Reported range of soil erosion } \\
\text { rates from literature } \\
\left(\left[\text { tons } / \mathrm{mi}^{2}\right] / \mathrm{yr}\right)\end{array}$ & $\begin{array}{l}\text { Simulated soil } \\
\text { erosion rates } \\
\left.\left.\text { ([tons } / \mathbf{m i}^{2}\right] / \mathrm{yr}^{1}\right)\end{array}$ & $\begin{array}{l}\text { Total sediment } \\
\text { production in } \\
\text { study area } \\
\text { (tons/yr) }\end{array}$ \\
\hline Open/developed & 173 & $\begin{array}{l}\text { 128-640 (U.S. Environmental Protection Agency, 2006); } \\
\text { 21-125 (Ockerman and others, 1999); } \\
17 \text { (Baird and others, 1996) }\end{array}$ & $167-252$ & 39,400 \\
\hline $\begin{array}{l}\text { Forest/rangeland/ } \\
\text { shrubland }\end{array}$ & 957 & 32-256 (U.S. Environmental Protection Agency, 2006) & $47-150$ & 80,500 \\
\hline Pasture & 763 & $\begin{array}{l}\text { 192-1,152 (U.S. Environmental Protection Agency, 2006); } \\
9 \text { (Ockerman, 2002) }\end{array}$ & $43-175$ & 67,400 \\
\hline Cropland & 163 & $\begin{array}{l}\text { 320-2,560 (U.S. Environmental Protection Agency, 2006); } \\
195 \text { (Ockerman and Petri, 2001); } \\
44 \text { and } 167 \text { (Ockerman and Fernandez, 2010) }\end{array}$ & $66-224$ & 22,900 \\
\hline Wetland & 83 & -- & $12-23$ & 1,260 \\
\hline
\end{tabular}

${ }^{1}$ Range of values of the four model watersheds in the study area.

${ }^{2}$ Area weighted average of total sediment production does not equal sediment leaving the study area because of losses from irrigation withdrawals or sediment retention in reservoirs.

to 0.89 ("very good" fit), with the exception of the Ecleto Runge gage which was 0.58 ("fair" fit). The monthly mean values for RSR were 0.41 to 0.53 ("good" to "very good"), again, with the Ecleto Runge gage being the exception with a RSR of 0.97 ("unsatisfactory" fit). The relative weakness of the model fit at the Ecleto Runge gage (compared to the model fit at other gages in the watersheds) likely reflects the accuracy of the streamflow calibration, which in turn, is likely affected by the lack of rainfall data available for the Ecleto model. At the SAR Goliad gage, testing results provide an important evaluation of the model's ability to accurately assess streamflow and suspended-sediment discharges near the outlet of the study area. The model-fit statistics indicate a "good" to "very good" fit.

Similar to the hydrology calibration, the suspendedsediment load model-fit statistics also were evaluated during the testing period at the SAR Falls City, Cibolo Falls City, and SAR Goliad gages. The percent differences indicated a slightly poorer fit than during the calibration period, ranging from -2.9 to -17.0 percent ("good" to "very good" fits). The monthly mean suspended-sediment NSE values were similar between the calibration and testing periods, with "very good" model fits for all three sites. The range of monthly mean suspendedsediment RSR values ( 0.36 to 0.51 ) indicated model fits of "good" to "very good."

During the 2000-12 simulation period, the suspendedsediment model-fit statistics at each of the calibration gages (SAR Falls City, Cibolo Falls City, and SAR Goliad) indicate "good" to "very good" fits. Overall, model-fit statistics and graphic evaluations from the calibration and testing periods provided multiple lines of evidence indicating that the USGS2014 model simulations of suspended-sediment conditions were mostly "good" to "very good," except at the Ecleto Runge gage, which is considered "unsatisfactory" to "fair."

\section{Parameter Calibration Values}

Calibration of the HSPF models resulted in a final set of model parameter values for simulation of streamflow and suspended-sediment loads for the study area. Selected parameter values (or ranges of values) related to hydrologic and suspended-sediment simulation are listed in appendix 1.

\section{Sensitivity Analysis}

Calibrated values of selected HSPF process-related parameters were further evaluated by a set of sensitivity analyses to determine the effects that changes in selected parameters would have on simulated streamflow and suspended-sediment loads. Each sensitivity simulation was made by adjusting a single parameter of the model by relatively large amounts (decreased by 25 percent) while keeping other model parameters unchanged. The percentage change was made for all values of the single parameter in all four watershed models. The sensitivity analyses simulations were performed for 2006-12. The resulting changes in streamflow and suspended-sediment loads were evaluated by comparing initial simulated streamflow (no parameter sensitivity changes) with adjusted simulated streamflow for 
each of the parameters. SAR Goliad was the simulation point for the evaluation of streamflow and sediment sensitivity. The results of the sensitivity analyses (changes in streamflow and suspended-sediment loads resulting from adjustments of selected parameters) are listed in table 8.

Simulated streamflow was relatively insensitive to adjustments of any of the selected parameters - none of the sensitivity simulation scenarios produced changes in streamflow greater than 10 percent. One reason is that most of the streamflow and sediment loads in the model study area originate upstream from the study area; streamflow and sediment loads entering the model study area from upstream were not affected by the change of any of the model parameters. The largest change in streamflow (increase of 8.8 percent) occurred as a result of changing the fraction of groundwater inflow to deep recharge (DEEPFR).

Suspended-sediment loads were more sensitive than streamflow to changes in selected process-related parameters. The most sensitive parameters were the index to infiltration capacity of soil (INFILT) and upper zone nominal storage (UZSN). Sensitivity simulations of INFILT, UZSN, and JSER resulted in an increase of sediment loads by 20 percent, 16 percent, and 14 percent, respectively. Other parameter adjustments that produced changes in suspended-sediment loads greater than 5 percent were lower zone nominal storage (LZSN) and the coefficient of detached-sediment washoff equation (KSER).

\section{Model Limitations}

The lower San Antonio River Basin model represents a complex natural system with a set of mathematical equations that describe the system. Intrinsic to the model is the error and uncertainty associated with the approximations, assumptions, and simplifications that must be made. Hydrologic modeling errors typically result from a combination of input data, representation of the physical processes by the algorithms of the model, and parameter estimation during the calibration process (Ely and Kahle, 2004).

There were uncertainties associated with model inputs such as rainfall, springflow, effluent discharge, and withdrawals which contributed to model result uncertainty. Uncertainties associated with the rainfall data used for model input were likely the most important source of model error. During storms, rainfall can vary substantially across the study area, and using only five rainfall precipitation stations to represent the 2,150- $\mathrm{mi}^{2}$ study area limits the accuracy of the rainfall input to the study area. Rainfall intensity is an important factor in estimation of runoff and sediment erosion and transport. The primary source of rainfall data for the USGS-2014 model were daily totals. Although data from several hourly rainfall stations were available to help disaggregate the daily totals to hourly values for part of the study period, there exists some uncertainty in the spatial and temporal representation of rainfall.

Table 8. Changes in simulated streamflow and suspended-sediment loads as a result of changes in selected Hydrological Simulation Program-FORTRAN (HSPF) process-related parameter values, 2006-12.

[SAR Goliad, U.S. Geological streamflow-gaging station 08188500 San Antonio River at Goliad, Texas; fts $/$, cubic feet per second; tons/d, tons per day]

\begin{tabular}{|c|c|c|c|c|c|c|c|c|c|}
\hline $\begin{array}{l}\text { Parameter } \\
\text { (app. 1) }\end{array}$ & $\begin{array}{l}\text { Initial } \\
\text { values }\end{array}$ & $\begin{array}{l}\text { Adjusted } \\
\text { values }\end{array}$ & $\begin{array}{l}\text { Change in } \\
\text { parameter } \\
\text { value } \\
\text { (percent) }\end{array}$ & $\begin{array}{c}\text { Initial } \\
\text { simulated } \\
\text { daily mean } \\
\text { streamflow } \\
\text { at SAR } \\
\text { Goliad } \\
\left(\mathrm{ft}^{3} / \mathrm{s}\right)\end{array}$ & $\begin{array}{c}\text { Adjusted } \\
\text { simulated } \\
\text { daily mean } \\
\text { streamflow } \\
\text { at SAR } \\
\text { Goliad } \\
\left(\mathrm{ft}^{3} / \mathbf{s}\right)\end{array}$ & $\begin{array}{l}\text { Change in } \\
\text { simulated } \\
\text { streamflow } \\
\text { (percent) }\end{array}$ & $\begin{array}{c}\text { Initial } \\
\text { simulated } \\
\text { daily mean } \\
\text { suspended- } \\
\text { sediment } \\
\text { load at SAR } \\
\text { Goliad } \\
\text { (tons/d) }\end{array}$ & $\begin{array}{c}\text { Adjusted } \\
\text { simulated } \\
\text { daily mean } \\
\text { suspended- } \\
\text { sediment } \\
\text { load at SAR } \\
\text { Goliad } \\
\text { (tons/d) }\end{array}$ & $\begin{array}{l}\text { Change in } \\
\text { simulated } \\
\text { suspended- } \\
\text { sediment } \\
\text { load } \\
\text { (percent) }\end{array}$ \\
\hline INFILT & $0.12-0.33$ & $0.09-0.25$ & -25 & 820 & 843 & 2.8 & 1,180 & 1,420 & 20 \\
\hline LZSN & $10.0-11.0$ & $7.50-8.25$ & -25 & 820 & 859 & 4.8 & 1,180 & 1,280 & 8.5 \\
\hline UZSN & $0.93-1.15$ & $0.70-0.86$ & -25 & 820 & 850 & 3.7 & 1,180 & 1,370 & 16 \\
\hline KRER & $0.05-0.45$ & $0.04-0.34$ & -25 & 820 & 820 & 0 & 1,180 & 1,160 & -1.7 \\
\hline M (silt) & 0.12 & 0.09 & -25 & 820 & 820 & 0 & 1,180 & 1,180 & 0 \\
\hline M (clay) & 0.12 & 0.09 & -25 & 820 & 820 & 0 & 1,180 & 1,180 & 0 \\
\hline
\end{tabular}


To help address rainfall spatial variability, DAYMET rainfall data were used as the input rainfall for the model. DAYMET rainfall takes into account rainfall data from multiple nearby National Weather Station precipitation stations, as available (Thornton and others, 2012). The DAYMET data are provided as daily totals. To help address the temporal representation of rainfall, the 2006-12 DAYMET data were disaggregated to hourly time steps by using available data from nearby USGS hourly rainfall gages; however, USGS hourly rainfall data for 2000-2005 were not available. Hence, hourly rainfall data from NWS Stinson were used to disaggregate DAYMET daily data for the NWS station 413201 Floresville, Tex. (hereinafter referred to as the "NWS Floresville station"), NWS Stockdale station, and the NWS station 417836 Runge, Tex. (hereinafter referred to as the "NWS Runge station”). For the NWS station 413618 Goliad, Tex. (hereinafter referred to as the "NWS Goliad station"), the daily rainfall data were disaggregated by using the BASINS disaggregation program. The resulting hourly rainfall data for model statistics during 2000-2005 indicate the model-fit statistics are not as good as during 2006-12. The hydrologic conditions in the study area are largely driven by the amount, timing, and intensity of the rainfall. Hence, without hourly rainfall data, the streamflow response is more challenging for the model to replicate. The Ecleto model, for example, had the weakest calibration statistics, which relied on rain-gage data from adjacent watersheds.

Suspended-sediment simulations also were possibly affected by uncertainties associated with rainfall and streamflow. For example, overestimation of rainfall intensity would increase soil particle detachment and washoff of sediment from PERLNDs, thereby possibly overestimating runoff and suspended-sediment concentrations and loads. Further, the sediment yield from different land-cover types as reported in literature can vary significantly based on sitespecific conditions such as soil type, land use, and location. Hence, though simulated sediment yields by land-cover type compared reasonably well with literature sediment yields, there are a limited number of studies in the south-central Texas area. Lastly, the daily suspended-sediment loads that were used as calibration targets were not measured daily loads but estimated based on the relations between streamflow and suspended-sediment concentrations (Crow and others, 2014). These relations were generally based on a large number of samples collected during a range of hydrologic concentrations. At the Cibolo Selma gage, however, the relation was based on very few samples, although they were collected during a range of streamflow conditions.

\section{Simulated Hydrologic Conditions in the Study Area in the San Antonio River Basin}

The USGS-2014 model was used to simulate hydrologic conditions of the study area within the San Antonio River Basin. The individual components of the hydrologic budget (precipitation, streamflow, evapotranspiration, and groundwater recharge) were simulated for the four watersheds during 2006-12 (fig. 13, table 9). During 2006-12, the daily mean streamflow at SAR Elmendorf and Cibolo Selma gages was 521 and $20 \mathrm{ft}^{3} / \mathrm{s}$, respectively. The daily mean streamflow leaving the study area, thus contributing to the Guadalupe River, was $865 \mathrm{ft}^{3} / \mathrm{s}$. Annual mean runoff from land surfaces were calculated for each model watershed by dividing the generated runoff volume of each watershed by the corresponding watershed area (table 9). It should be noted that the simulated runoff might not equal the streamflow exiting the watershed because of the effects of withdrawals from streams (irrigation and evapotranspiration) and discharges to the stream (wastewater and rainfall on the stream surface). Of the four watersheds, the Cibolo Creek watershed had the largest annual mean runoff from land surfaces (2.7 inches per year). The SAR watershed upstream from Cibolo Creek had the smallest annual mean runoff (1.9 inches) (table 9).

The USGS-2014 model results indicate that after rainfall, evapotranspiration is the next largest component of the water budget (table 9). Simulated evapotranspiration was generally consistent between watersheds, ranging from 23.6 to 26.6 inches per year.

The simulated annual mean groundwater recharge varied across the study area by watershed, but more notably by water-budget zone (table 10). The greatest rate of simulated annual mean groundwater recharge (4.2 inches per year) was in zone 3, which is the zone with the highest qualitative soil infiltration rates (fig. 3), and corresponds to the outcrop of the Carrizo Sand geologic unit in the Texas Coastal Uplands aquifer system (fig. 2). The lowest simulated annual mean groundwater recharge (1.7 inches per year) was in zone 9, which includes outcrops of the Lissie, Deweyville, and Beaumont Formations, and composes the Texas Coastal Lowlands aquifer system. These simulated groundwater recharge values are in general agreement with groundwater recharge values reported by the University of Texas Bureau of Economic Geology (Scanlon and others, 2003). The reported groundwater recharge rates ranged from 0.1 to 5.8 inches per year in the Carrizo-Wilcox aquifer (which is part of the Texas Coastal Uplands aquifer system) and 0.0004 to 2 inches per year for the Texas Coastal Lowlands aquifer system (Scanlon and others, 2003). 


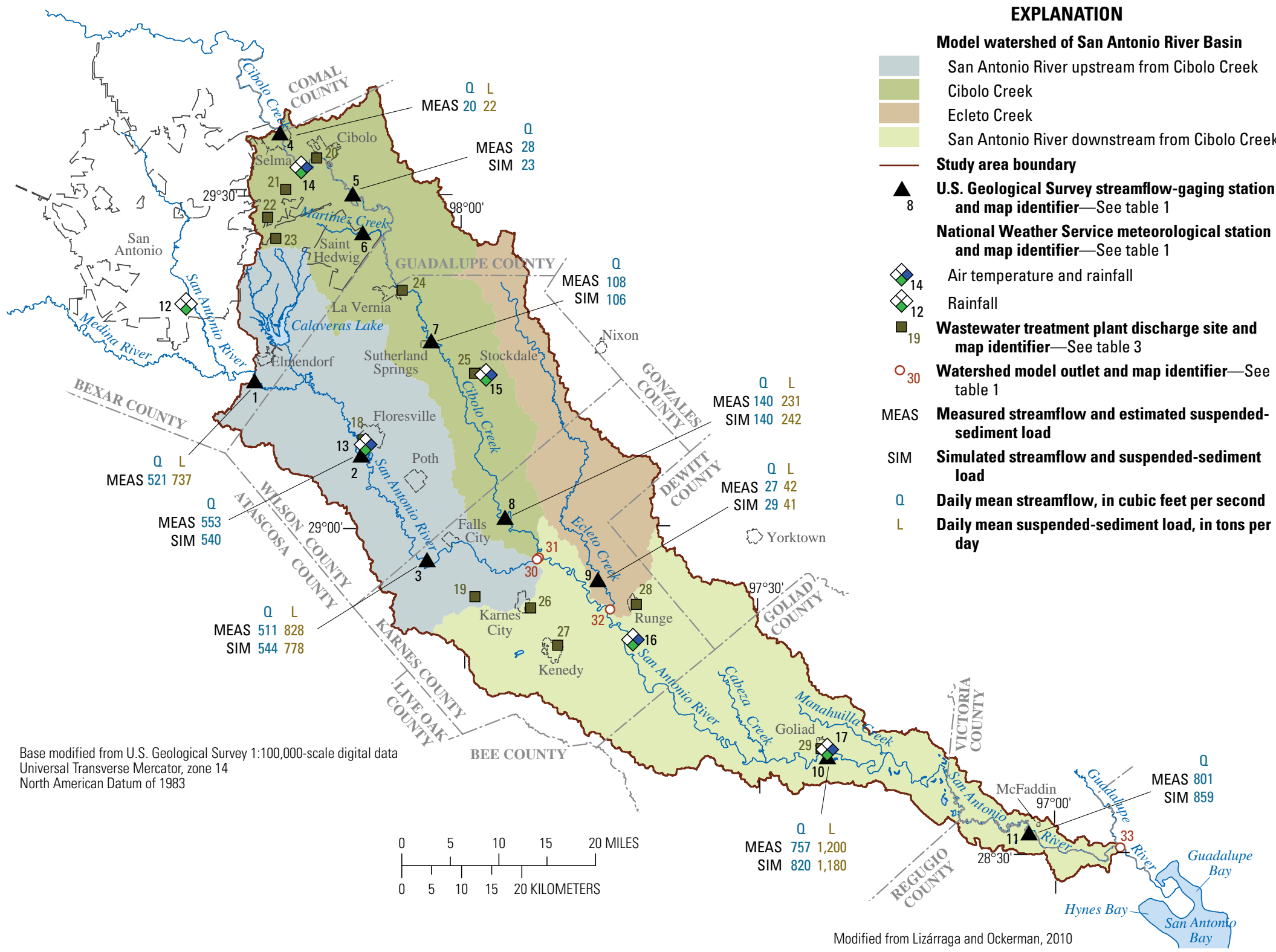

Figure 13. Measured and simulated daily mean streamflow and daily mean suspended-sediment loads at selected sites in the study area, San Antonio River Basin downstream from San Antonio, Texas, 2006-12. 
Table 9. Simulated hydrologic and suspended-sediment conditions upstream from and within the study area, San Antonio River Basin downstream from San Antonio, Texas, 2006-12.

[in/yr, inches per year; $\mathrm{ft}^{3} / \mathrm{s}$, cubic feet per second; tons/d, tons per day; $\left(\right.$ tons $\left./ \mathrm{mi}^{2}\right) / \mathrm{yr}$, tons per square mile per year; --, not applicable; SAR Elmendorf, USGS station 08181800 San Antonio River near Elmendorf, Texas; Cibolo Selma, USGS station 08185000 Cibolo Creek at Selma, Texas]

\begin{tabular}{|c|c|c|c|c|c|c|c|c|}
\hline Watershed & $\begin{array}{l}\text { Drainage } \\
\text { area } \\
\text { (square } \\
\text { miles) }\end{array}$ & $\begin{array}{c}\text { Annual } \\
\text { mean } \\
\text { rainfall } \\
\text { (in/yr) }\end{array}$ & $\begin{array}{l}\text { Annual } \\
\text { mean } \\
\text { runoff } \\
\text { from land } \\
\text { surfaces } \\
\text { (in/yr) }\end{array}$ & $\begin{array}{c}\text { Annual } \\
\text { mean } \\
\text { evapotrans- } \\
\text { piration } \\
\text { (in/yr) }\end{array}$ & $\begin{array}{c}\text { Annual } \\
\text { mean } \\
\text { groundwater } \\
\text { recharge } \\
\text { (in/yr) }\end{array}$ & $\begin{array}{c}\text { Daily } \\
\text { mean } \\
\text { streamflow' } \\
\left(\mathbf{f t}^{3} / \mathbf{s}\right)\end{array}$ & $\begin{array}{c}\text { Daily } \\
\text { mean } \\
\text { suspended- } \\
\text { sediment } \\
\text { load }^{2} \\
\text { (tons/d) }\end{array}$ & $\begin{array}{c}\text { Annual } \\
\text { mean } \\
\text { suspended- } \\
\text { sediment } \\
\text { yield } \\
\left.\left.\text { ([tons } / \text { mi }^{2}\right] / y r\right)\end{array}$ \\
\hline $\begin{array}{l}\text { San Antonio River upstream } \\
\text { from the study area (inflow at } \\
\text { SAR Elmendorf) }\end{array}$ & 1,743 & -- & -- & -- & -- & 521 & 737 & 154 \\
\hline $\begin{array}{l}\text { Cibolo Creek watershed } \\
\text { upstream from the study area } \\
\text { (inflow at Cibolo Selma) }\end{array}$ & 274 & -- & -- & -- & -- & 20 & 22 & 30 \\
\hline $\begin{array}{l}\text { San Antonio River watershed } \\
\text { upstream from Cibolo Creek }\end{array}$ & 554 & 29.7 & 1.9 & 24.6 & 3.1 & 571 & 831 & 62 \\
\hline Cibolo Creek watershed & 579 & 29.3 & 2.7 & 23.6 & 3.1 & 146 & 252 & 145 \\
\hline Ecleto Creek watershed & 266 & 29.0 & 2.1 & 24.1 & 3.2 & 31 & 43 & 59 \\
\hline $\begin{array}{l}\text { San Antonio River watershed } \\
\text { downstream from Cibolo } \\
\text { Creek }\end{array}$ & 751 & 30.8 & 2.1 & 26.6 & 2.0 & 865 & 1,230 & 51 \\
\hline $\begin{array}{l}\text { San Antonio River Basin study } \\
\text { area }\end{array}$ & 2,150 & 29.9 & 2.2 & 25.0 & 2.7 & 865 & 1,230 & 80 \\
\hline
\end{tabular}

${ }^{1}$ Daily mean streamflow exiting the watershed during 2006-12, including inflows from upstream watersheds.

${ }^{2}$ Daily mean suspended-sediment load exiting the watershed during 2006-12, including inflows from upstream watersheds.

${ }^{3}$ Yields calculated as suspended sediment produced in the modeled watershed, which does not include inflows from upstream watersheds.

Table 10. Simulated groundwater recharge by water-budget zone in the study area, San Antonio River Basin downstream from San Antonio, Texas, 2006-12.

\begin{tabular}{cc}
\hline $\begin{array}{c}\text { Water-budget } \\
\text { zone }\end{array}$ & $\begin{array}{c}\text { Simulated annual } \\
\text { mean groundwater } \\
\text { recharge rates } \\
\text { (inches) }\end{array}$ \\
\hline Zone 1 & 2.8 \\
Zone 2 & 3.2 \\
Zone 3 & 4.2 \\
Zone 4 & 3.2 \\
Zone 5 & 3.0 \\
Zone 6 & 2.2 \\
Zone 7 & 2.5 \\
Zone 8 & 2.0 \\
Zone 9 & 1.7 \\
\hline
\end{tabular}




\section{Simulated Suspended-Sediment Loads and Yields in the Study Area in the San Antonio River Basin}

The USGS-2014 model of the study area in the San Antonio River Basin also was used to estimate suspendedsediment loads of the study area during 2006-12 within the San Antonio River Basin, which were delivered to the confluence of the San Antonio River and the Guadalupe River. The 2006-12 simulated mean suspended-sediment loads at each of the calibration and testing sites are shown in table 5 and figure 13 . The estimated daily mean suspendedsediment loads were 737 tons per day (tons/d) and 22 tons/d, respectively, at the SAR Elmendorf and Cibolo Selma gages during 2006-12 (table 9). Simulated suspended-sediment loads (including inflows from upstream watersheds) were 831 tons/d from the upper SAR model, 252 tons/d from the Cibolo model, and 43 tons/d from the Ecleto model. At the outlet of the study area, the confluence of the San Antonio River with the Guadalupe River, the simulated annual mean suspendedsediment load during 2006-12 was 1,230 tons/d. These model results indicate that 759 of the 1,230 tons/d (approximately 62 percent) of the suspended sediment being delivered to the Guadalupe River originates upstream from the study area, mainly upstream from the SAR Elmendorf gage. Model results indicate that most of the suspended-sediment load in the study area consists of silt- and clay-sized particles (less than 0.0625 millimeters). At the confluence of the San Antonio River with the Guadalupe River, approximately 98 percent of the total simulated suspended-sediment load consisted of silt and clay.

Different land-cover types resulted in different simulated soil erosion rates contributing to the suspended-sediment loads in the study area (fig. 4). Open space and developed land-cover categories were combined in the model output of sediment (hereinafter referred to as "open/developed") because open space is a subcategory of developed and the barren land was a relatively small percent of the total land-cover area. Open/developed and cropland land-cover categories exhibited the highest simulated soil erosion rates (table 7). Simulated soil erosion rates from the open/developed land-use category ranged from 167 to 252 tons per square mile per year ([tons $\left.\left./ \mathrm{mi}^{2}\right] / \mathrm{yr}\right)(2006-12)$. Cropland simulated soil erosion rates ranged from 66 to 224 (tons $/ \mathrm{mi}^{2}$ )/yr. Together, cropland and open/developed categories composed about 16 percent of the study area (table 2) and contributed about 29 percent of the total sediment produced within the study area (table 7). Model output of sediment for forest (8.2 percent of the study area) and rangeland and shrubland (36.3 percent of the study area) were combined (hereinafter referred to as "forest/rangeland/shrubland") because they exhibited similar hydrologic and sediment simulation response. The forest/ rangeland/shrubland category generated about 38 percent of the total sediment produced within the study area. Pasture land (35.3 percent of the study area) produced about 32 percent of the total sediment generated within the study area (table 7).
Wetlands (3.9 percent of the study area) contributed less than 1 percent of the total sediment produced within the study area (table 7). It should be noted that the total sediment production does not equal the suspended-sediment loads leaving the study area because of sediment losses associated with withdrawals or sediment retention in reservoirs.

Simulated suspended-sediment yields by watershed (which only includes suspended sediment produced within that watershed) are shown in table 9. Simulated annual mean suspended sediment yields were 62 (tons $\left./ \mathrm{mi}^{2}\right) / \mathrm{yr}$ from the upper SAR model, 145 (tons $\left./ \mathrm{mi}^{2}\right) / \mathrm{yr}$ from the Cibolo model, $59\left(\right.$ tons $\left./ \mathrm{mi}^{2}\right) / \mathrm{yr}$ from the Ecleto model, and 51 (tons $\left./ \mathrm{mi}^{2}\right) / \mathrm{yr}$ in the lower SAR model during 2006-12. Overall, the simulated annual mean suspended-sediment yield in the study area was $80\left(\right.$ tons $\left./ \mathrm{mi}^{2}\right) / \mathrm{yr}$. The higher annual mean suspended-sediment yields in the Cibolo Creek watershed are likely because of steeper topography, more developed and cropland land cover, and more runoff compared to the other watersheds in the study area.

\section{Summary}

Suspended sediment in rivers and streams can play an important role in ecological health of rivers and estuaries and consequently is an important issue for water-resource managers. To better understand suspended-sediment loads and transport in a watershed, a Hydrological Simulation Program-FORTRAN (HSPF) model was developed to simulate hydrologic conditions and suspended-sediment loads in the San Antonio River Basin, downstream from San Antonio, Texas. In 2010, the U.S. Geological Survey (USGS), in cooperation with the San Antonio River Authority, the Evergreen Underground Water Conservation District, and the Goliad County Groundwater Conservation District, developed an HSPF model for the San Antonio River Basin to simulate hydrology only (hereinafter referred to as the “USGS-2010 model”). In 2012, URS Corporation developed an updated version of the San Antonio River Basin HSPF model (hereinafter referred to as the "URS-2012 model"), which was based on the USGS-2010 model. For this study, the USGS, in cooperation with the San Antonio River Authority, developed an updated version of the HSPF model, based on the URS-2012 model, to simulate hydrologic conditions and suspended-sediment loads in the San Antonio River Basin during 2000-12 (hereinafter referred to as the "USGS-2014 model”). The USGS-2014 model used available historical suspended-sediment data, as well as recently collected data (2011-13) at selected locations in the study area to calibrate the model sediment simulation.

The study area consists of approximately 2,150 square miles encompassing parts of Bexar, Guadalupe, Wilson, Karnes, DeWitt, Goliad, Victoria, and Refugio Counties. The upstream boundary of the study area coincides with USGS streamflow-gaging station 08181800 San Antonio River 
near Elmendorf, Tex. (hereinafter referred to as the "SAR Elmendorf gage") and USGS streamflow-gaging station 08185000 Cibolo Creek at Selma, Tex. (hereinafter referred to as the "Cibolo Selma gage"). The downstream boundary of the study area is the confluence with the Guadalupe River. The HSPF model of the study area was developed by (1) configuring the model to represent the study area in the San Antonio River Basin and (2) compiling and processing required meteorological, streamflow, and sediment input data. Because of the large size of the study area, the study area in the San Antonio River Basin was divided into four watershed models: (1) San Antonio River upstream from Cibolo Creek, (2) Cibolo Creek, (3) Ecleto Creek, and (4) San Antonio River downstream from Cibolo Creek. Input data for the HSPF model included spatial and time-series data. Spatial data included geology, soils, land-cover, topography, and drainage characteristics such as subwatershed boundaries and streamreach length and cross-section data. Time-series data included meteorological data (rainfall and potential evapotranspiration), streamflow data, and suspended-sediment load data.

The calibrated model of the study area in the San Antonio River Basin was used to simulate hydrologic conditions and suspended-sediment loads for 2000-12, as well as to simulate sediment production by various land types within the study area. Taking into consideration the model-fit statistics and graphical comparisons, the watershed models simulated the observed streamflow within the "good" to "very good" categories during the calibration period (2006-12), with the exception of the Ecleto model. The calibration process also included a separate, post-calibration test of the model fit during 2000-2005. Simulations during the testing period had similar model-fit statistics as during the calibration period, with the exception of the Cibolo Falls City gage. One possible reason for weaker testing results (compared with calibration results) is that the quality of available rainfall data for 20002005 was likely poorer than the 2006-12 data. During the entire 2000-12 simulation period, the model-fit statistics at each of the primary calibration gages; the USGS streamflowgaging station 08183500 San Antonio River near Falls City, Tex., (hereinafter referred to as the "SAR Falls City gage”), the USGS streamflow-gaging station 08186000 Cibolo Creek near Falls City, Tex., (hereinafter referred to as the "Cibolo Falls City gage"), and the USGS streamflow-gaging station 08188500 San Antonio River at Goliad, Tex., (hereinafter referred to as the "SAR Goliad gage") indicate "good" to "very good" fits. Overall, model-fit statistics and graphic evaluations from the calibration and testing periods provided multiple lines of evidence indicating the USGS-2014 model simulations of hydrologic conditions were mostly "good" to "very good."

Similar to the hydrology calibration, the suspendedsediment load model-fit statistics also were evaluated during the testing period at the SAR Falls City, Cibolo Falls City, and SAR Goliad gages, resulting in "good” to "very good" fits. Overall, model-fit statistics and graphic evaluations from the calibration and testing periods, provided multiple lines of evidence indicating the USGS-2014 model simulations of suspended-sediment conditions were mostly "good" to "very good," except for Ecleto Runge, which is considered unsatisfactory to fair. The ranges of expected soil erosion rates were used as guidance for establishing targets for model simulation of sediment yields for different land-cover types. Sediment-related HSPF model parameters were adjusted so that simulated soil erosion rates approximated the reported soil erosion rates by land-cover type.

The daily mean estimated suspended-sediment loads were 737 tons per day (tons/d) and 22 tons/d, respectively, at the SAR Elmendorf and Cibolo Selma gages during 2006-12. At the outlet of the study area, the confluence of the San Antonio River with the Guadalupe River, the simulated daily mean suspended-sediment load during 2006-12 was 1,230 tons/d. These model results indicate that 759 of the 1,230 tons/d (approximately 62 percent) of the suspended sediment being delivered to the Guadalupe River originates upstream from the study area, mostly upstream from the SAR Elmendorf gage. Sample analyses and model results indicate that most of the suspended-sediment load in the study area consists of silt- and clay-sized particles (less than 0.0625 millimeters). At the confluence of the San Antonio River with the Guadalupe River, approximately 98 percent of the total simulated suspended-sediment load was composed of silt and clay.

The Cibolo Creek watershed was the largest contributor of suspended sediment from the study area. The higher suspended-sediment yields in the Cibolo Creek watershed are likely because of steeper topography, more developed and cropland land cover, and more runoff than the other watersheds. For the entire study area, open/developed land and cropland exhibited the highest simulated soil erosion rates; however, the largest sources of sediment from the study area (by land-cover type) were pasture and forest/rangeland/ shrubland, which account for about 80 percent of the study area and contributed about 70 percent of the suspendedsediment load.

\section{References}

Aronow, S., Brown, T.E., Brewton, J.L., Eargle, D.H., and Barnes, V.E., 1987, Geologic atlas of Texas, GA0005 Beeville-Bay City sheet: Austin, The University of Texas, Bureau of Economic Geology, 4 p., 1 sheet.

Ashworth, J.B., and Hopkins, Janie, 1995, Major and minor aquifers of Texas: Texas Water Development Board Report 345, 69 p.

Baird, F.C., Jennings, Marshall, Dybala, T.J., and Ockerman, D.J., 1996, Characterization of nonpoint sources and loadings to the Corpus Christi Bay National Estuary Program study area: Corpus Christi Bay National Estuary Program, CCBNEP-05, 225 p. 
Bicknell, B.R., Imhoff, J.C., Kittle, J.L., Jr., Donigian, A.S., and Johanson, R.C., 2001, Hydrological Simulation Program-FORTRAN, user's manual for version 12: Research Triangle Park, N.C., U.S. Environmental Protection Agency, National Exposure Research Laboratory, Office of Research and Development, $843 \mathrm{p}$.

Bidlake, W.R., 2002, Evapotranspiration from selected fallowed agricultural fields on the Tule Lake National Wildlife Refuge, California, during May to October 2000: U.S. Geological Survey Water-Resources Investigations Report 02-4055, 59 p.

Brown, T.E., Waechter, N.B., and Barnes, V.E., 1983, Geologic atlas of Texas, GA0029 San Antonio sheet: Austin, The University of Texas, Bureau of Economic Geology, 8 p., 1 sheet.

Brown, T.E., Waechter, N.B., Owens, F., Howeth, I., and Barnes, V.E., 1976, Geologic atlas of Texas, GA0011 Crystal-City Eagle Pass sheet: Austin, The University of Texas, Bureau of Economic Geology, 6 p., 1 sheet.

Crow, C.L., Banta, J.R., and Opsahl, S.P., 2014, Sediment characteristics in the San Antonio River Basin downstream from San Antonio, Texas, and at a site on the Guadalupe River downstream from the San Antonio River Basin, 19662013: U.S. Geological Survey Scientific Investigations Report 2014-5048, 33 p.

Donigian, A.S., Jr., 2002, Watershed model calibration and validation-The HSPF experience, in Conference on National TMDL Science and Policy 2002, Phoenix, Ariz., November 13-16, 2002, Proceedings: Alexandria, Va., Water Environment Federation, p. 44-73, accessed July 30, 2014, at http://www.aquaterra.com/resources/pubs/index. php.

Donigian, A.S., Jr., Bicknell, B.R., and Imhoff, J.C., 1995, Hydrological Simulation Program-FORTRAN (HSPF), in Singh, V.P., ed., Computer models of watershed hydrology: Highlands Ranch, Colo., Water Resources Publications, p. 395-442.

Donigian, A.S., Jr., Imhoff, J.C., Bicknell, B.R., and Kittle, J.L., Jr., 1984, Application guide for Hydrological Simulation Program—FORTRAN (HSPF): Athens, Ga., U.S. Environmental Protection Agency, Environmental Research Laboratory, EPA-600/3-84-065, 177 p.

Edwards Aquifer Authority, 2014, Technical data: Accessed January 17, 2014, at http://www.edwardsaquifer.org/aquiferdata-and-maps/j17-data.

Ely, D.M., and Kahle, S.C., 2004, Conceptual model and numerical simulation of the ground-water-flow system in the unconsolidated deposits of the Colville River watershed, Stevens County, Washington: U.S. Geological Survey Scientific Investigations Report 2004-5237, 71 p.
Evenson, E.J., Orndorff, R.C., Blome, C.D., Böhlke, J.K., Hershberger, P.K., Langenheim, V.E., McCabe, G.J., Morlock, S.E., Reeves, H.W., Verdin, J.P., Weyers, H.S., and Wood, T.M., Strategic directions for U.S. Geological Survey Water Science, 2012-2022-Observing, understanding, predicting, and delivering Water Science to the NationPublic review release: U.S. Geological Survey Open-File Report 2012-1066, 42 p., accessed August 8, 2014, at http:// pubs.usgs.gov/of/2012/1066/.

Fry, J., Xian, G., Jin, S., Dewitz, J., Homer, C., Yang, L., Barnes, C., Herold, N., and Wickham, J., 2011, Completion of the 2006 National Land Cover Database for the conterminous United States: Photogrammetric Engineering and Remote Sensing, v. 77, no. 9, p. 858-864.

Helsel, D.R., and Hirsch, R.M., 2002, Statistical methods in water resources: U.S. Geological Survey Techniques of Water-Resources Investigations, book 4, chap. A3, 522 p.

Homer, C., Dewitz, J., Fry, J., Coan, M., Hossain, N., Larson, C., Herold, N., McKerrow, A., VanDriel, J.N., and Wickham, J., 2007, Completion of the 2001 National Land Cover Database for the conterminous United States: Photogrammetric Engineering and Remote Sensing, v. 73, no. 4, p. 337-341.

Hummel, P., Kittle, J., and Gray, M., 2001, WDMUtil, version 2.0-A tool for managing watershed modeling time-series data: U.S. Environmental Protection Agency Contract No. 68-C-98-010, 157 p.

Kasmarek, M.C., and Robinson, J.L., 2004, Hydrogeology and simulation of ground-water flow and land-surface subsidence in the northern part of the Gulf Coast aquifer system, Texas: U.S. Geological Survey Scientific Investigations Report 2004-5102, 111 p.

Kittle, J.L., Jr., Lumb, A.M., Hummel, P.R., Duda, P.B., and Gray, M.H., 1998, A tool for the generation and analysis of model simulations scenarios for watersheds (GenScn): U.S. Geological Survey Water-Resources Investigations Report 98-4134, 152 p.

Linsley, R.K., Kohler, M.A., and Paulhus, J.L.H., 1982, Hydrology for engineers (3d ed.): New York, McGraw-Hill, $512 \mathrm{p}$.

Lizárraga, J.S., and Ockerman, D.J., 2010, Simulation of streamflow, evapotranspiration, and groundwater recharge in the lower San Antonio River watershed, south-central Texas, 2000-2007: U.S. Geological Survey Scientific Investigations Report 2010-5027, 41 p.

Lizárraga, J.S., and Wehmeyer, L.L., 2012, Estimation of streamflow gains and losses in the lower San Antonio River watershed, south-central Texas, 2006-10: U.S. Geological Survey Scientific Investigations Report 20125073, 34 p. 
Markus, M., and Demissie, M., 2006, Predictability of annual sediment load based on flood events: Journal of Hydraulic Engineering, v. 11, no. 4, p. 354-461.

Martin, G.R., Zarriello, P.J., and Shipp, A.A., 2001, Hydrologic and water-quality characterization and modeling of the Chenoweth Run Basin, Jefferson County, Kentucky: U.S. Geological Survey Water-Resources Investigations Report 00-4239, $197 \mathrm{p}$.

Milliman, J.D., and Meade, R.H., 1983, World-wide delivery of river sediment to the oceans: Journal of Geology, v. 91, p. 1-21.

Moran, P.W., Calhoun, D.L., Nowell, L.H., Kemble, N.E., Ingersoll, C.G., Hladik, M.L., Kuivila, K.M., Falcone, J.A., and Gilliom, R.J., 2012, Contaminants in stream sediments from seven U.S. metropolitan areas—Data summary of a National Pilot Study: U.S. Geological Survey Scientific Investigations Report 2011-5092, 66 p.

Moriasi, D.N., Arnold, J.G., Van Liew, M.W., Bingner, R.L., Harmel, R.D., and Veith, T.L., 2007, Model evaluation guidelines for systematic quantification of accuracy in watershed simulation: Transaction of American Society of Agricultural and Biological Engineers, v. 50, no. 3, p. 885900.

Multi-Resolution Land Characteristics Consortium, 2013, National land cover database 2006: Accessed August 1, 2013, at http://www.mrlc.gov/nlcd06_data.php.

Nash, J.E., and Sutcliffe, J.V., 1970, River flow forecasting through conceptual models, part 1-A discussion of principles: Journal of Hydrology, v. 10, no. 3, p. 282-290.

National Oceanic and Atmospheric Administration, 2013, Web climate services: National Oceanic and Atmospheric Administration data, accessed December 27, 2013, at http:// www.ncdc.noaa.gov/oa/climate/stationlocator.html.

Natural Resources Conservation Service, 2013, Soil Survey Geographic (SSURGO) database for Bexar, Guadalupe, Wilson, Karnes, DeWitt, Goliad, Victoria, and Refugio Counties, Texas: Accessed September 15, 2013, at http:// sdmdataaccess.nrcs.usda.gov/.

Ockerman, D.J., 2002, Hydrologic conditions and quality of rainfall and storm runoff in agricultural and rangeland areas in San Patricio County, Texas, 2000-2001: U.S. Geological Survey Open-File Report 02-291, 20 p., 1 pl.

Ockerman, D.J., 2007, Simulation of streamflow and estimation of ground-water recharge in the upper Cibolo Creek watershed, south-central Texas, 1992-2004: U.S. Geological Survey Scientific Investigations Report 2007-5202, 34 p.

Ockerman, D.J., and Fernandez, C.J., 2010, Hydrologic conditions and quality of rainfall and storm runoff for two agricultural areas of the Oso Creek watershed, Nueces County, Texas, 2005-08: U.S. Geological Survey Scientific Investigations Report 2010-5136, 63 p.
Ockerman, D.J., Heitmuller, F.T., and Wehmeyer, L.L., 2013, Sources suspended-sediment loads in the lower Nueces River watershed, downstream from Lake Corpus Christi to the Nueces estuary, south Texas, 1958-2010: U.S. Geological Survey Scientific Investigations Report 20135159, 56 p.

Ockerman, D.J., and McNamara, K.C., 2003, Simulation of streamflow and estimation of streamflow constituent loads in the San Antonio River watershed, Bexar County, Texas, 1997-2001: U.S. Geological Survey Water-Resources Investigations Report 03-4030, 37 p.

Ockerman, D.J., and Petri, B.L., 2001, Hydrologic conditions and water quality in an agricultural area in Kleberg and Nueces Counties, Texas, 1997-98: U.S. Geological Survey Water-Resources Investigations Report 01-4101, 36 p., 2 app.

Ockerman, D.J., Petri, B.L., and Slattery, R.N., 1999, Stormwater runoff for selected watersheds in the Edwards Aquifer recharge zone, Bexar County, Texas, 1996-98: U.S. Geological Survey Fact Sheet FS-172-98, 6 p.

Proctor, C.V., Jr., Brown, T.E., Waechter, N.B., Aronow, S., and Barnes, V.E., 1974, Geologic atlas of Texas, GA0030 Seguin sheet: Austin, The University of Texas, Bureau of Economic Geology, 6 p., 1 sheet.

Ryder, P.D., 1996, Ground water atlas of the United StatesSegment 4, Oklahoma, Texas: U.S. Geological Survey Hydrologic Investigations Atlas 730-E, 30 p.

Scanlon, B.R., Dutton, Alan, and Sophocleous, Marios, 2003, Groundwater recharge in Texas: Austin, University of Texas, Bureau of Economic Geology, Lawrence, Kans., Kansas Geological Survey, 80 p.

Singh, V.P., 1995, Watershed modeling, in Singh, V.P., ed., Computer models of watershed hydrology: Highlands Ranch, Colo., Water Resources Publications, p. 1-22.

Slattery, R.N., Asquith, W.H., and Ockerman, D.J., 2011, Rainfall and evapotranspiration data for southwest Medina County, Texas, August 2006-December 2009: U.S. Geological Survey Data Series 554, 28 p.

Texas Commission on Environmental Quality, 2011, Environmental flow recommendations report: Final submission to the Guadalupe, San Antonio, Mission, and Aransas Rivers and Mission, Copano, Aransas, and San Antonio Bays Basin and Bay Area Stakeholder Committee, Environmental Flows Advisory Group, and Texas Commission on Environmental Quality, 427 p., accessed on August 8, 2014, at http://www.tceq.state. tx.us/assets/public/permitting/watersupply/water_rights/ eflows/20110301guadbbest_transmission.pdf. 
Thornton, P.E., Thornton, M.M., Mayer, B.W., Wilhelmi, N., Wei, Y., and Cook, R.B., 2012, Daymet-Daily surface weather on a $1 \mathrm{~km}$ grid for North America,1980-2012: Oak Ridge, Tenn., Oak Ridge National Laboratory Distributed Active Archive Center accessed April 10, 2014, at http:// daymet.ornl.gov/.

URS Corporation, 2012, Lower San Antonio River watershed HSPF model calibration: URS Corporation, 54 p.

U.S. Environmental Protection Agency, 2000, Estimating hydrology and hydraulic parameters for HSPF: U.S. Environmental Protection Agency Better Assessment Science Integrating Point and Nonpoint Sources Technical Note 6, 34 p., accessed April 29, 2014, at http://water.epa. gov/scitech/datait/models/basins/upload/2000_08_14_ BASINS_tecnote6.pdf.

U.S. Environmental Protection Agency, 2006, Sediment parameter and calibration guidance for HSPF: U.S. Environmental Protection Agency Better Assessment Science Integrating Point and Nonpoint Sources Technical Note 8, 43 p., accessed April 29, 2014, at http://water.epa. gov/scitech/datait/models/basins/upload/2006_02_02_ BASINS_tecnote8.pdf.
U.S. Environmental Protection Agency, 2013, Better assessment science integrating point and nonpoint sources (BASINS), BASINS user information and guidance, September 2013: accessed March 15, 2014, at http://water. epa.gov/scitech/datait/models/basins/userinfo.cfm.

U.S. Geological Survey, 2009, Collection, quality assurance, and presentation of precipitation data: Office of Surface Water Technical Memorandum No. 2006.01 (revised December 2009), accessed June 23, 2014, at http://water. usgs.gov/admin/memo/SW/sw06.012_Revised_122009.pdf.

U.S. Geological Survey, 2014a, The National MapElevation: Accessed February 28, 2014, at http:// nationalmap.gov/elevation.html.

U.S. Geological Survey, 2014b, National Water Information System-Web interface (NWISWeb) data: Accessed February 28, 2014, at http://waterdata.usgs.gov/tx/nwis/ nwis.

U.S. Geological Survey, 2014c, National Hydrography Dataset: Accessed April 29, 2014, at http://nhd.usgs.gov/ data.html.

Wood, P.J., and Armitage, P.D., 1997, Biological effects of fine sediment in the lotic environment: Environmental Management, v. 21, no. 2, p. 203-217. 


\section{Appendix 1-Hydrological Simulation Program-FORTRAN Parameter Definitions and Values}



Appendix 1. Summary of calibrated values for selected hydrologic and sediment-related parameters for the Hydrological Simulation Program-FORTRAN model by waterbudget zone in the study area, San Antonio River Basin downstream from San Antonio, Texas.

[PERLND, pervious land surface; IMPLND, impervious land surface; RCHRES, stream/reservoir reach; --, not applicable; /, per]

\begin{tabular}{|c|c|c|c|c|c|c|c|c|c|c|c|c|}
\hline Parameter & Module unit & Description & Zone 1 & Zone 2 & Zone 3 & Zone 4 & Zone 5 & Zone 6 & Zone 7 & Zone 8 & Zone 9 & Units \\
\hline \multicolumn{13}{|c|}{ Hydrologic parameters } \\
\hline AGWETP & PERLND & $\begin{array}{l}\text { Fraction of available } \\
\text { evapotranspiration from active } \\
\text { groundwater }\end{array}$ & $0.04-0.04$ & $0.04-0.05$ & $0.04-0.05$ & $0.04-0.05$ & $0.04-0.05$ & $0.04-0.05$ & $0.04-0.05$ & $0.04-0.04$ & $0.04-0.04$ & -- \\
\hline AGWRC & PERLND & Base groundwater recession rate & 0.92 & 0.92 & 0.92 & 0.92 & 0.92 & 0.92 & $0.92-0.94$ & 0.94 & 0.94 & 1/day \\
\hline BASETP & PERLND & $\begin{array}{l}\text { Fraction of available } \\
\text { evapotranspiration from base flow }\end{array}$ & $0.05-0.08$ & $0.05-0.08$ & $0.05-0.08$ & $0.05-0.08$ & $0.05-0.08$ & $0.05-0.08$ & $0.05-0.08$ & 0.04 & 0.04 & -- \\
\hline CEPSC & PERLND & Interception storage capacity & $0.22-0.22$ & $0.22-0.22$ & $0.20-0.22$ & $0.22-0.22$ & $0.22-0.22$ & $0.22-0.22$ & $0.22-0.22$ & $0.22-0.25$ & $0.22-0.25$ & inch \\
\hline DEEPFR & PERLND & $\begin{array}{l}\text { Fraction of groundwater inflow to } \\
\text { deep recharge }\end{array}$ & $0.69-0.69$ & $0.69-0.71$ & $0.81-0.85$ & $0.68-0.7$ & $0.65-0.67$ & $0.40-0.50$ & 0.59 & 0.5 & 0.4 & -- \\
\hline INFEXP & PERLND & Infiltration equation exponent & $1.9-2.0$ & $1.9-2.0$ & $1.9-2.0$ & $1.9-2.0$ & $1.9-2.0$ & $1.9-2.0$ & $1.9-2.0$ & 2.0 & 2.0 & -- \\
\hline INFILD & PERLND & $\begin{array}{l}\text { Ratio of maximum to mean } \\
\text { infiltration rate }\end{array}$ & 2.0 & 2.0 & 2.0 & 2.0 & 2.0 & 2.0 & 2.0 & 2.0 & 2.0 & -- \\
\hline INFILT & PERLND & Index to infiltration capacity of soil & 0.16 & $0.20-0.23$ & $0.30-0.33$ & $0.25-0.28$ & $0.16-0.27$ & $0.16-0.22$ & $0.18-0.22$ & 0.17 & 0.17 & inch/hour \\
\hline INTFW & PERLND & Index to interflow & 1.0 & 1.0 & 1.0 & 1.0 & 1.0 & 1.0 & $1.0-1.5$ & 1.5 & 1.5 & -- \\
\hline IRC & PERLND & Interflow recession coefficient & 0.5 & $0.5-0.7$ & $0.5-0.7$ & $0.5-0.7$ & $0.5-0.7$ & $0.5-0.7$ & $0.5-0.7$ & 0.7 & 0.7 & 1/day \\
\hline KVARY & PERLND & Groundwater outflow modifier & 3 & 3 & $2-3$ & $2-3$ & $2-3$ & $2-3$ & $2-3$ & 3 & 3 & 1/inch \\
\hline LSUR & $\begin{array}{l}\text { PERLND or } \\
\text { IMPLND }\end{array}$ & $\begin{array}{l}\text { Average length of assumed overland- } \\
\text { flow plane }\end{array}$ & 250 & 250 & 250 & 250 & 250 & 250 & $250-300$ & 250-300 & $250-300$ & foot \\
\hline LZETP & PERLND & Lower-zone evapotranspiration & $0.6-0.7$ & $0.6-0.7$ & $0.6-0.7$ & $0.6-0.7$ & $0.6-0.7$ & $0.6-0.7$ & $0.6-0.7$ & $0.6-0.7$ & $0.6-0.7$ & -- \\
\hline LZSN & PERLND & Lower-zone nominal storage & 10 & $10-11$ & $10-11$ & $10-11$ & $10-11$ & $10-11$ & $10-11$ & 11 & 11 & inch \\
\hline NSUR & $\begin{array}{l}\text { PERLND or } \\
\text { IMPLND }\end{array}$ & $\begin{array}{l}\text { Manning's n for assumed overland- } \\
\text { flow plane }\end{array}$ & 0.15 & $0.15-0.20$ & $0.15-0.25$ & $0.15-0.25$ & $0.15-0.25$ & $0.15-0.25$ & $0.15-0.25$ & 0.20 & 0.20 & -- \\
\hline RETSC & PERLND & $\begin{array}{l}\text { Retention storage capacity of } \\
\text { impervious areas }\end{array}$ & $0.10-0.20$ & $0.10-0.20$ & $0.10-0.20$ & $0.10-0.20$ & $0.10-0.20$ & $0.10-0.20$ & $0.10-0.20$ & $0.10-0.20$ & $0.10-0.20$ & inch \\
\hline SLSUR & $\begin{array}{l}\text { PERLND or } \\
\text { IMPLND }\end{array}$ & $\begin{array}{l}\text { Average slope of assumed overland- } \\
\text { flow plane }\end{array}$ & 0.03 & 0.03 & 0.03 & 0.03 & 0.03 & 0.03 & 0.03 & 0.03 & 0.03 & -- \\
\hline UZSN & PERLND & Upper-zone nominal storage & $0.93-0.93$ & $0.93-1.15$ & $0.93-1.15$ & $0.97-1.15$ & $0.97-1.15$ & $0.97-1.15$ & $0.97-1.15$ & 1.10 & 1.10 & inch \\
\hline \multicolumn{13}{|c|}{ Sediment parameters } \\
\hline KRER & PERLND & $\begin{array}{l}\text { Coefficient of soil-detachment } \\
\text { equation }\end{array}$ & $0.33-0.41$ & $0.33-0.45$ & $0.25-0.45$ & $0.30-0.45$ & $0.30-0.45$ & $0.30-0.45$ & $0.30-0.45$ & $0.33-0.41$ & $0.33-0.41$ & complex \\
\hline JRER & PERLND & Exponent of soil-detachment equation & 2.0 & 2.0 & 2.0 & 2.0 & 2.0 & 2.0 & 2.0 & 2.0 & 2.0 & complex \\
\hline KSER & PERLND & $\begin{array}{l}\text { Coefficient of detached-sediment } \\
\text { washoff equation }\end{array}$ & $0.52-2.46$ & $0.52-2.56$ & $0.52-2.56$ & $0.52-2.56$ & $0.52-2.56$ & $0.52-2.56$ & $0.52-2.56$ & $0.67-2.36$ & $0.67-2.36$ & complex \\
\hline
\end{tabular}


Appendix 1. Summary of calibrated values for selected hydrologic and sediment-related parameters for the Hydrological Simulation Program—FORTRAN model by waterbudget zone in the study area, San Antonio River Basin downstream from San Antonio, Texas.-Continued

[PERLND, pervious land surface; IMPLND, impervious land surface; RCHRES, stream/reservoir reach; --, not applicable; /, per]

\begin{tabular}{|c|c|c|c|c|c|c|c|c|c|c|c|c|}
\hline Parameter & Module unit & Description & Zone 1 & Zone 2 & Zone 3 & Zone 4 & Zone 5 & Zone 6 & Zone 7 & Zone 8 & Zone 9 & Units \\
\hline \multicolumn{13}{|c|}{ Sediment parameters-Continued } \\
\hline JSER & PERLND & $\begin{array}{l}\text { Exponent of detached-sediment } \\
\text { washoff equation }\end{array}$ & 2.9 & $2.9-3.0$ & $2.5-3.0$ & $2.5-3.0$ & $2.5-3.0$ & $2.5-3.0$ & $2.5-3.0$ & 3.0 & 3.0 & complex \\
\hline KGER & PERLND & Coefficient of matrix scour equation & $0.00-0.20$ & $0.00-0.20$ & $0.00-0.20$ & $0.00-0.20$ & $0.00-0.20$ & $0.00-0.20$ & $0.00-0.20$ & $0.00-0.20$ & $0.00-0.20$ & complex \\
\hline JSER & PERLND & Exponent of matrix scour equation & 2.5 & 2.5 & 2.5 & 2.5 & 2.5 & 2.5 & 2.5 & 2.5 & 2.5 & complex \\
\hline KEIM & IMPLND & Coefficient of solids washoff equation & 0.18 & 0.18 & 0.18 & 0.18 & 0.18 & 0.18 & 0.18 & 0.18 & 0.18 & complex \\
\hline JEIM & IMPLND & Exponent of solids washoff equation & 2.0 & 2.0 & 2.0 & 2.0 & 2.0 & 2.0 & 2.0 & 2.0 & 2.0 & complex \\
\hline AFFIX & PERLND & $\begin{array}{l}\text { Fraction by which detached sediment } \\
\text { decreases daily through soil } \\
\text { compaction }\end{array}$ & 0.05 & 0.05 & 0.05 & 0.05 & 0.05 & 0.05 & 0.05 & 0.05 & 0.05 & 1/day \\
\hline COVER & PERLND & $\begin{array}{l}\text { Fraction of land surface shielded from } \\
\text { rainfall erosion }{ }^{1,2}\end{array}$ & $0.10-0.80$ & -- & -- & -- & -- & -- & -- & -- & -- & none \\
\hline NVSI & PERLND & $\begin{array}{l}\text { Rate at which sediment enters } \\
\text { detached-sediment storage from } \\
\text { atmosphere }\end{array}$ & 0.3 & 0.3 & 0.3 & 0.3 & 0.3 & 0.3 & 0.3 & 0.3 & 0.3 & $\begin{array}{l}\text { pound/acre- } \\
\text { day }\end{array}$ \\
\hline ACCSDP & IMPLND & Solids accumulation rate & 0.10 & 0.10 & 0.10 & 0.10 & 0.10 & 0.10 & 0.10 & 0.10 & 0.10 & ton/acre-day \\
\hline RHO & RCHRES & Density of sediment particle & 2.6 & 2.6 & 2.6 & 2.6 & 2.6 & 2.6 & 2.6 & 2.6 & 2.6 & $\begin{array}{l}\text { gram/cubic } \\
\text { centimeter }\end{array}$ \\
\hline M (silt) & RCHRES & Erodibility coefficient of sediment & 0.12 & 0.12 & 0.12 & 0.12 & 0.12 & 0.12 & 0.12 & 0.12 & 0.12 & $\begin{array}{l}\text { pound/square } \\
\text { foot-day }\end{array}$ \\
\hline M (clay) & RCHRES & Erodibility coefficient of sediment & 0.12 & 0.12 & 0.12 & 0.12 & 0.12 & 0.12 & 0.12 & 0.12 & 0.12 & $\begin{array}{l}\text { pound/square } \\
\text { foot-day }\end{array}$ \\
\hline $\begin{array}{l}\text { W (silt } \\
\text { and } \\
\text { clay) }\end{array}$ & RCHRES & $\begin{array}{l}\text { Settling velocity of sediment particle } \\
\text { in still water }\end{array}$ & 0.0005 & 0.0005 & 0.0005 & 0.0005 & 0.0005 & 0.0005 & 0.0005 & 0.0005 & 0.0005 & inch/second \\
\hline $\begin{array}{l}\text { TAUCD } \\
\text { (silt) }\end{array}$ & RCHRES & $\begin{array}{l}\text { Critical bed shear stress for sediment } \\
\text { deposition }{ }^{2}\end{array}$ & $0.001-0.95$ & -- & -- & -- & -- & -- & -- & -- & -- & $\begin{array}{l}\text { pound/square } \\
\text { foot }\end{array}$ \\
\hline $\begin{array}{l}\text { TAUCS } \\
\text { (silt) }\end{array}$ & RCHRES & $\begin{array}{l}\text { Critical bed shear stress for sediment } \\
\text { scour }^{2}\end{array}$ & $0.001-1.35$ & -- & -- & -- & -- & -- & -- & -- & -- & $\begin{array}{l}\text { pound/square } \\
\text { foot }\end{array}$ \\
\hline $\begin{array}{r}\text { TAUCD } \\
\text { (clay) }\end{array}$ & RCHRES & $\begin{array}{l}\text { Critical bed shear stress for sediment } \\
\text { deposition }{ }^{2}\end{array}$ & $0.001-0.26$ & -- & -- & -- & -- & -- & -- & -- & -- & $\begin{array}{l}\text { pound/square } \\
\text { foot }\end{array}$ \\
\hline $\begin{array}{r}\text { TAUCS } \\
\text { (clay) }\end{array}$ & RCHRES & $\begin{array}{l}\text { Critical bed shear stress for sediment } \\
\text { scour }^{2}\end{array}$ & $0.002-1.30$ & -- & -- & -- & -- & -- & -- & -- & -- & $\begin{array}{l}\text { pound/square } \\
\text { foot }\end{array}$ \\
\hline
\end{tabular}

${ }^{1}$ Range represents monthly values.

${ }^{2}$ Range represents values from zones 1 through 9. 
Publishing support provided by

Lafayette and Rolla Publishing Service Centers

Information regarding water resources in Texas is available at http://tx.usgs.gov/ 

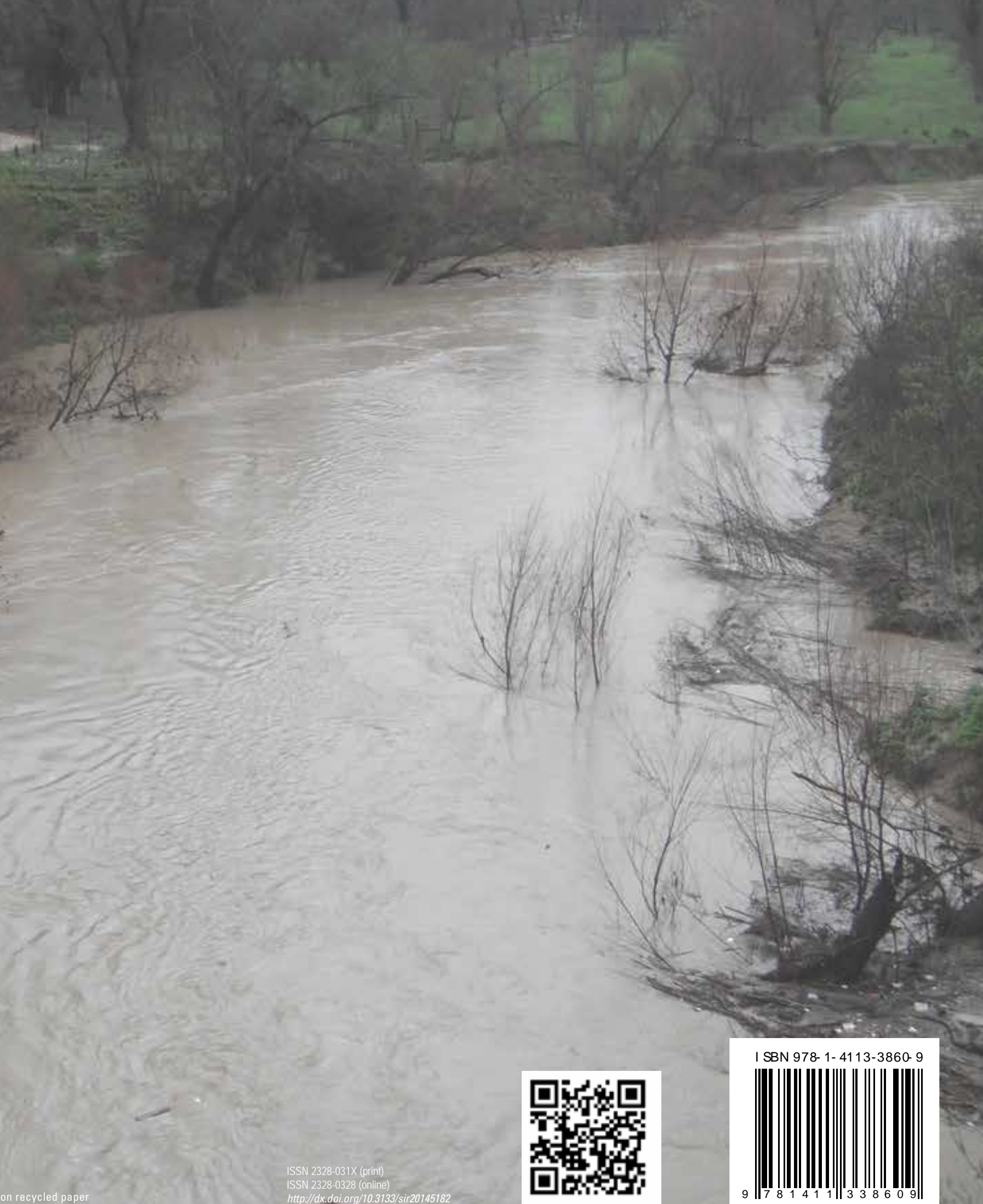

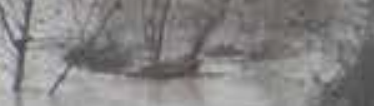
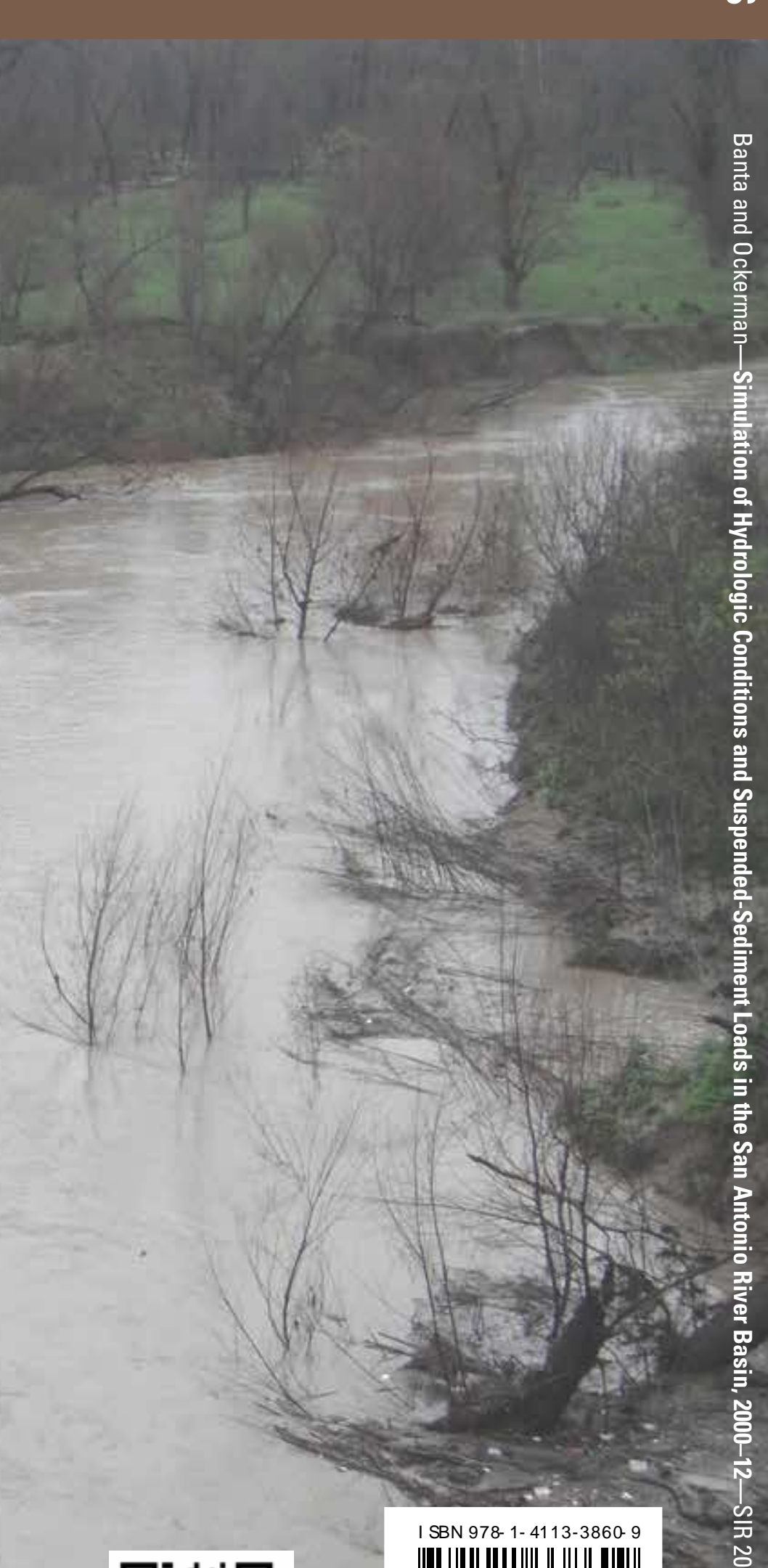

I SBN 978- 1- 4113-3860- 9

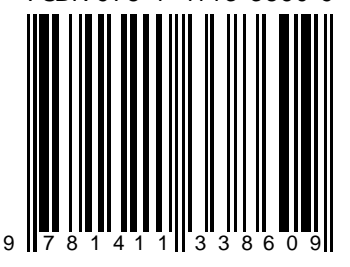

